Biogeosciences Discuss., https://doi.org/10.5194/bg-2017-383

Manuscript under review for journal Biogeosciences

Discussion started: 1 November 2017

(c) Author(s) 2017. CC BY 4.0 License.

\title{
Historical record of the effects of anthropogenic pollution on benthic foraminifera over the last 110 years in Gamak Bay, South Korea
}

\author{
Da Un Jeong ${ }^{1}$, Yeon Gyu Lee ${ }^{1}$, Yong Wan Kim², Jung Jun Park ${ }^{3}$, Jung Sick Lee ${ }^{4}$, \\ ${ }^{1}$ Faculty of Marine Technology, Chonnam National University, Yeosu, 59626, Republic of Korea \\ $5 \quad{ }^{2}$ Center for Research Facilities, Chonnam National University, Yeosu, 59626, Republic of Korea \\ ${ }^{3}$ South Sea Fisheries Research Institute, NIFS, Yeosu, 59780, Republic of Korea \\ ${ }^{4}$ Faculty of Aqualife Medicine, Chonnam National University, Yeosu, 59626, Republic of Korea
}

Correspondence to: Yeon Gyu Lee (lyg6342@jnu.ac.kr)

Abstract. This study investigated the historical record of the effects that anthropogenic pollution has had on benthic

10 foraminifera over the last 110 years in the semi-closed Gamak Bay. The evidence consisted of geochemical data including ${ }^{210} \mathrm{~Pb}$ concentrations and benthic foraminiferal assemblages acquired from core sediments (western, eastern and northwestern areas). Various records of benthic foraminiferal assemblage in the northwestern area were suitable as the standard for variation regarding pollution history. In the period between 1906 and 1964 (the pre-urbanization period), Gamak Bay was composed of Ammonia beccarii-Elphidium advenum-Elphidium clavatum assemblage, except for the northwestern area with A. beccarii-

15 Buccella frigida-E. advenum assemblage, and may have remained mostly unpolluted. Although the northwestern area did not show a difference in the species composition of the benthic foraminifera, it may be polluted to some degree due to stagnant sewage supplied from a small village that had formed before city construction in the hinterland, as shown from the species diversity of 1.37, with a total number of benthic foraminifera (TNBF) of 704 individual and total organic carbon/total sulfur $(\mathrm{C} / \mathrm{S})$ of 2.63 .

20 The benthic foraminiferal assemblage of the northernmost area between 1965 and 1987 (the urbanization period) rapidly varied from E. somaense-A. beccarii-B. frigida assemblage, through A. beccarii-B. frigida-E. advenum, B. frigida-A. beccarii-E. subarcticum, T. hadai-E. subarcticum-B. frigida, to A. beccarii-E. subarcticum-T. hadai assemblage with a diversity of 1.8, TNBF of 244, C/S of 2.05 on average. During this period, it was characterized by an increase in abundance frequency in $T$. hadai, and E. subarcticum, which are known as bioindicators of eutrophication and organic pollution, respectively, and rapid

25 variation of benthic foraminiferal assemblage. These may have been caused by an increase in the influx of sewage from Yeosu City, which was constructed at the hinterland of the northernmost area in Gamak Bay, as shown from the sedimentation rate of $1.0 \mathrm{~cm} / \mathrm{y}$. Pollution during the urbanization period may have been restricted to the northwestern area, and it did not diffuse to the surrounding area.

The E. subarctum, A. beccarii-E. subarcticum-T. hadai and E. subarcticum assemblages with diversity of 1.35, TNBF of 562,

$30 \mathrm{C} / \mathrm{S}$ of 2.33 were sequentially distributed in the northwestern area from 1988 to 2014 (the aquaculture period), and this is characterized by the high abundance frequency of E. subarcticum of $51 \%$ and high sedimentation rate of $1.75 \mathrm{~cm} / \mathrm{y}$ caused by 
Biogeosciences Discuss., https://doi.org/10.5194/bg-2017-383

Manuscript under review for journal Biogeosciences

Discussion started: 1 November 2017

(c) Author(s) 2017. CC BY 4.0 License.

biodeposits discharged from mussel farming (Mytilus galloprovincialis) since the 1980s. The organic pollution materials originated from and deposited by biodeposits may contribute to the continuous deterioration and variation in the benthic ecological environment by means of "pollution storage". During this period, benthic foraminiferal assemblages in the northwestern area are correlated with the E. subarcticum-A. beccarii assemblage of the eastern area where oyster farming has taken place, and it is composed of E. subarcticum (35.4\%) and A. beccarii (15.5\%) with a TNBF of 1787 individuals, species diversity of 2.18, C/S of 4.8 and a sedimentation rate of $0.95 \mathrm{~cm} /$ year. It is clear that the northern area seriously progressed in pollution compared to the eastern area, although the species composition is somewhat similar between the two areas. It may be caused by an overabundance and excessive deposition of the organic matter through an over-supply from mussel farming as well as the oval-shaped bottom physiography and very slow current speed. During the transition from the pre-urbanization to urbanization period, and aquaculture period in the northwestern area, the processes of variation in the benthic foraminiferal assemblages may represent the transition from oxic to anoxic environmental conditions. The western area with A. beccarii-E. advenum-E. clavatum assemblage, however, was unpolluted over the last 110 years. These differences in the degree of pollution and benthic foraminiferal assemblages between the areas in Gamak Bay may be caused by the physiography and current movements of the bay.

\section{Introduction}

Over the last few centuries, coastal areas have experienced a dramatic degradation in environmental quality as a result of anthropogenic activity, and this has led to a considerable reduction in marine biodiversity. The anthropogenic impact on coastal marine ecosystems has multiple origins, including the introduction of urban sewage, outflows from industrial and agricultural activities including fisheries, and other environmental problems including eutrophication, oxygen deficiency, chemical pollution, and physical disturbance (Barras et al., 2014; Yasuhara et al., 2012).

Sediments are an essential, integral, and dynamic part of an aquatic environment and can act not only as a sink for various environmental chemicals, but also as a potential long-term secondary source of pollutants (Ridgway and Shimmield, 2002). The geochemical study of vertical sediment cores has been extensively used to reconstruct environmental transformation of different coastal areas all over the world (Cearreta et al., 2002; Di Gregorio et al., 2007). In the sedimentary record, interactions

25 between meiofaunal and geochemical elements have made it possible to distinguish between unimpacted, pre-industrial intervals and sediments deposited in industrial periods. (Francescangeli et al., 2016).

Benthic foraminifera have been commonly used in reconstructions of the environmental changes over the past several centuries, including changes caused by human activity (Scott et al., 2005; Tsujimoto et al., 2008; Irabien et al., 2008; Dolven et al., 2013; Romano et al., 2016; Francescangeli et al., 2016). Benthic foraminifera can become fossilized and can act as reliable indicators

30 of environmental change over historical and geological time scales (Gooday et al., 2009). The fossil remains of benthic foraminifera can provide information of the long-term environmental and biological changes, whether natural or human- 
Biogeosciences Discuss., https://doi.org/10.5194/bg-2017-383

Manuscript under review for journal Biogeosciences

Discussion started: 1 November 2017

(c) Author(s) 2017. CC BY 4.0 License.

induced (Alve et al., 2009). Foraminifera offer considerable advantages over other groups of benthic organisms because their hard shells (called "tests") often persist as a record in the sediment and their small size makes them abundant even in smallvolume samples. Thus they can be considered a reliable data source for statistical purposes. These characteristics make foraminifera suitable indicators for environmental studies of sediment cores and offer the opportunity to study temporal changes in the ecological conditions (Romano et al., 2016). Moreover, since environmental quality must be assessed through a comparison with reference conditions, sediment cores offer the advantage of including ancient deposits reflecting conditions from before human impact in lieu of searching pristine areas with the same characteristics as the targeted study area (Alve et al., 2009).

The coastal zones of Korea began to undergo urbanization in earnest in the 1910s with increased fossil fuel (especially coal) consumption (Jeong et al., 2006; Lim et al., 2012, 2013). Gamak Bay, which is located at the center of the southern coastal area of Korea, is known to experience problems in its coastal environments, including eutrophication, hypoxia, and red tide events caused by an influx of anthropogenic pollutants, particularly organic matter (Lee et al., 2009; Lee et al., 2012, 2016; Seo et al., 2012). Historically, this relatively small bay has been subjected to a combination of environmental pressures that mainly arise from aquaculture and industrial activities, and it is therefore a good case study of historical variations in

15 anthropogenic impacts. The purpose of this study is to investigate historical anthropogenic pollution as recorded by benthic foraminifera over the last 110 years in Gamak Bay through an interpretation of geochemical data, including ${ }^{210} \mathrm{~Pb}$ concentrations and benthic foraminiferal assemblage data acquired from core sediments.

\section{Study area}

Gamak Bay is located at the center of the South Sea coast of Korea. It is an oval-shaped, semi-enclosed bay surrounded by

20 Yeosu and Dolsan islands (Figure 1). It has an area of $148 \mathrm{~km}^{2}$, approximately $15 \mathrm{~km}$ in length and $9 \mathrm{~km}$ in width (Lee et al., 1995). The bedrock beneath Gamak Bay is composed mainly of Cretaceous alkali-feldspar granite, andesite and andesitic tuff, a volcanic rock of intermediate composition with an aphanitic texture (KIGAM, 2002). The surface sediments of Gamak Bay consist mainly of fine-grained silt and clay facies, although coarse-grained sediments are predominant at the mouth of the bay (Lee et al., 1995).

25 The average water depth of the bay is $9 \mathrm{~m}$, with relatively shallow water ( $<5 \mathrm{~m} \mathrm{depth}$ ) in the center increasing to 30 $\mathrm{m}$ at the mouth of the bay. The tide is semidiurnal, and the tidal fluctuation is quite large, with minimum and maximum tidal amplitudes of $\sim 1 \mathrm{~m}$ and $\sim 4 \mathrm{~m}$ during the neap and spring tides, respectively. The bay has two channels, one to the east and one to the south, but the southern channel is responsible for approximately 80\% of all seawater exchange in the bay (Lee and Chang, 1982). Tidal waves enter or exit almost simultaneously via these two channels with relative proportions of exchange (Lee et

30 al., 2009). The sea water of the bay can be divided into three water masses: (1) water in the northwestern area with a current that generally flows counterclockwise with water that is quite stagnant due to the bottom topography, residual bottom currents 
Biogeosciences Discuss., https://doi.org/10.5194/bg-2017-383

Manuscript under review for journal Biogeosciences

Discussion started: 1 November 2017

(c) Author(s) 2017. CC BY 4.0 License.

with mean velocity of about $2 \mathrm{~cm} \cdot \mathrm{s}^{-1}$ (Lee, 1992), and oxygen deficiency in the bottom water during the summer (Lee et al, 2016); (2) Yeosu Harbor water in the northeastern area with a lower salinity due to the influence of small streams and ditches; and (3) water in the center and near the mouth of the bay with a generally clockwise current (Lee and Cho, 1990) and residual bottom currents with mean velocity of about $4 \mathrm{~cm} \cdot \mathrm{s}^{-1}$ (Lee et al., 2016).

5 The bay is home to many commercially important marine organisms, including oysters, mussels, ark clams, rockfish, sea bream, and flounder. Mussels and oysters are cultivated mostly using suspended longline systems and have been farmed in the northwestern and eastern areas of Gamak Bay, respectively, since the late 1970s, which makes this area important to the fishing industry. This bay was designated by the Korean government (Ministry of Land Transport and Maritime Affairs, MLTM) as an environmental conservation area in February of 2000 based on its ecological importance as a habitat for fish and shellfish

10 (Kim, 2003). However, increased human activities with an expansion of nearby urban areas since the 1970s, as well as the development of various aquaculture industries including oyster and mussel farming in recent decades, have caused a gradual increase in the influx of anthropogenic pollutants, particularly organic matter. These pollutants have caused environmental problems at the coast, including eutrophication, hypoxia, and red tide events, especially during the summer (Lee et al., 2009; Seo et al., 2012; Lee et al., 2012, 2016). These phenomena have occurred continuously, even though a sewage treatment plant

15 began operation in 2004 to restrain the influx of sewage from urban areas (Kim et al., 2006; Lee and Moon, 2006; Lee et al., 2009). Much of the current pollution in Gamak Bay originates from aquaculture activities and polluted surface sediments (Lee et al., 2016).

\section{Materials and methods}

\subsection{Sediment sampling}

20 A core sediment sampling was conducted in August 2015 at three stations in representative localities of the western (St. 11257), eastern (St. 10863) and northwestern (St. 11285) areas of Gamak Bay (Figure 1). These three sediment cores, with lengths of $40 \mathrm{~cm}, 44 \mathrm{~cm}$ and $60 \mathrm{~cm}$, respectively, were extracted using a gravity corer of $76 \mathrm{~mm}$ in diameter and were analyzed in 2-cm intervals to examine grain size, trace metals, organic matter (OM), total organic carbon (TOC), total nitrogen (TN), total sulfur (TS), $\mathrm{pH},{ }^{210} \mathrm{~Pb}$ radioactivity, and benthic foraminifera.

\section{$25 \quad 3.2$ Grain size composition and geochemical analysis}

Prior to a grain size analysis, the organic material and carbonates were eliminated from the sample by sequentially adding $10 \%$ hydrogen peroxide $\left(\mathrm{H}_{2} \mathrm{O}_{2}\right)$ and $0.1 \mathrm{~N}$ hydrochloric acid $(\mathrm{HCl})$. Subsequently, the samples were subjected to a Sedigraph 5100 automatic particle size analyzer to measure the fine fraction $(<63 \mu \mathrm{m})$ and sieve analysis for the coarse fraction. The weights of the coarse and fine samples were recorded as weight percentages for each section (Folk, 1968). 
Biogeosciences Discuss., https://doi.org/10.5194/bg-2017-383

Manuscript under review for journal Biogeosciences

Discussion started: 1 November 2017

(c) Author(s) 2017. CC BY 4.0 License.

For the trace metal analysis, the samples were freeze-dried and ground to a fine powder with an agate mortar. A 0.25 -g portion of each sample was measured into a Teflon decomposition container, into which $6 \mathrm{~mL}$ of $\mathrm{HNO}_{3}(65 \%), 1 \mathrm{~mL}$ of $\mathrm{HClO}_{4}(65 \%)$, and $1 \mathrm{~mL}$ of $\mathrm{H}_{2} \mathrm{O}_{2}$ (30\%) were added. The mixture was processed with the decomposition sequence of a microwave decomposition system (ETHOS TC, Milestone, Italy). After cooling, the mixture was diluted to $50 \mathrm{~mL}$ with $0.1 \%$ nitric acid.

5 These samples were used for inductively coupled plasma optical mass spectrometry (ICP-MS, NexION®300X). Only the concentrations of $\mathrm{Al}, \mathrm{Fe}, \mathrm{Mn}, \mathrm{Zn}, \mathrm{Cr}, \mathrm{Ni}, \mathrm{Cu}, \mathrm{Co}, \mathrm{As}, \mathrm{Cd}, \mathrm{Pb}$, and $\mathrm{Hg}$ were considered. The detection limits for each of these metals were: Al, $0.005 \mu \mathrm{g} \mathrm{kg}^{-1}$; Fe, $0.0003 \mu \mathrm{g} \mathrm{kg}^{-1}$; Mn, $0.00007 \mu \mathrm{g} \mathrm{kg}^{-1} ; \mathrm{Zn}, 0.0003 \mu \mathrm{g} \mathrm{kg}^{-1} ; \mathrm{Cr}, 0.0002 \mu \mathrm{g} \mathrm{kg}{ }^{-1} ; \mathrm{Ni}, 0.0004$ $\mu \mathrm{g} \mathrm{kg}{ }^{-1}$; $\mathrm{Cu}, 0.0002 \mu \mathrm{g} \mathrm{kg}^{-1}$; Co, $0.0009 \mu \mathrm{g} \mathrm{kg}$; As, $0.0006 \mu \mathrm{g} \mathrm{kg}{ }^{-1}$; Cd, $0.00009 \mu \mathrm{g} \mathrm{kg}^{-1} ; \mathrm{Pb}^{-1} 0.00004 \mu \mathrm{g} \mathrm{kg}{ }^{-1}$; and Hg, $0.0003 \mu \mathrm{g} \mathrm{kg}^{-1}$. Trace metal concentrations were compared to the ER-L (Effect Range-Low) and ER-M (Effect Range-Median)

10 values reported in the sediment guidelines of the U.S. Environmental Protection Agency (USEPA) (Long et al., 1995). Subsamples (30-40 mg) were oven-dried at $50{ }^{\circ} \mathrm{C}$ and were pulverized to a silt size using an agate mortar; $10 \mathrm{mg}$ of each of these samples were enclosed in thin Ag film cups. Next, $1 \mathrm{M} \mathrm{HCl}$ was added to these samples, and these were dried at $11{ }^{\circ} \mathrm{C}$ for 30 min. TOC, TN, and TS contents were then measured with an elemental analyzer (Flash 2000, Thermo Scientific, Italy). Each sediment core sample was oven-dried at $60{ }^{\circ} \mathrm{C}$ immediately after the fieldwork. After the shells had been removed, the

15 samples were homogenized using a mortar and pestle. After homogenization, 3-5 g subsamples were placed in pre-weighed crucibles that were then placed in a desiccator overnight to remove any remaining moisture. The samples were weighed before being placed in a small furnace for $4 \mathrm{~h}$ at $550{ }^{\circ} \mathrm{C}$ and were then cooled in a desiccator overnight and reweighed. Loss on ignition (LOI) was calculated as follows: LOI\% $=[($ Initial Dry Mass - Final Dry Mass)/Initial Dry Mass $] \times 100($ modified from Dean, 1974).

20 The sediment $\mathrm{pH}$ was measured using a pH Spear (Oakton, Eutech Instruments, Singapore) with a pH range of -1.00 to 15.00 $\mathrm{pH}$ and a resolution of $0.01 \mathrm{pH}$.

\section{$3.3{ }^{210} \mathrm{~Pb}$ radioactivity}

With a nearly uniform grain size, the sediment composition of the three cores may indicate that trace metals have accumulated in a very stable sedimentary environment. In this case, the pollution history of these sediments can be successfully reconstructed using ${ }^{210} \mathrm{~Pb}$ radiometric dating alone without normalizing for the concentrations of pollutant metals or referring to other time markers (Kitano et al., 1980; Grousset et al., 1999). Once heavy metals are released into shallow marine environments, they are removed from the water column through interactions with suspended particles and are subsequently deposited as bottom sediments (Callender, 2003). Since heavy metals deposited in sediments are not biodegradable, the metal profiles of the sediment cores, in combination with ${ }^{210} \mathrm{~Pb}$ dating techniques, can be used as records of pollution events (Cantwell et al., 2007; Ip et al., 2007; Irabien et al., 2008; Lim et al., 2012). 
Biogeosciences Discuss., https://doi.org/10.5194/bg-2017-383

Manuscript under review for journal Biogeosciences

Discussion started: 1 November 2017

(c) Author(s) 2017. CC BY 4.0 License.

Measurements of ${ }^{210} \mathrm{~Pb}$, which has a 22.3-year half-life, were obtained from the sediment core by the Korea Basic Science Institute. The total ${ }^{210} \mathrm{~Pb}$ activity was determined based on the quantification of deposition of the granddaughter isotope ${ }^{210} \mathrm{Po}$ on an Ag disc in conjunction with a ${ }^{209}$ Po chemical tracer (Ruiz-Fernández et al., 2003; Lubis, 2006).

\subsection{Foraminiferal analysis}

5 An analysis of the benthic foraminifera in core sediments was conducted at 2-cm intervals. Samples for this analysis were washed over a $63-\mu \mathrm{m}$ sieve and were oven-dried at $50^{\circ} \mathrm{C}$. After further drying, these samples were subdivided using a modified Otto microsplitter. Foraminifera were counted under a binocular microscope from a known fraction, or the full sample was counted. A minimum of 200 individuals were counted from each interval. The benthic foraminifera taxonomy used in this paper is based on works by Asano (1950, 1951a, b, 1952), Matoba (1970), and Loeblich and Tappan (1994).

10 The total numbers of benthic foraminifera, the numbers of individuals per $20 \mathrm{~mL}$, species diversity, and species evenness were statistically analyzed. Species diversity ( $\left.\mathrm{H}^{\prime}\right)$ and evenness (J) were calculated using formulas presented by Shannon and Weaver (1963) and Pielou (1966).

To determine the structure of the foraminiferal data set, we performed Q-mode clustering techniques with the paired group algorithm based on Bray-Curtis similarity which provided grouped averaged data for square-root-transformed abundance data.

15 All statistical analyses were performed on foraminiferal relative abundance data sets using all species. Q-mode cluster analyses were carried out using the PRIMER 6 software (Plymouth Routines in Multivariate Ecological Research, UK). A correlation matrix was calculated for transformed geochemical elements and dominant species.

For the structural refinement, principal component analysis (PCA) was conducted to identify similarities and differences among foraminiferal assemblages. This technique reduces large data matrices composed of several variables to a small number of factors that represent the main modes of variation, facilitating the interpretation of large volumes of data. PCA was carried out for the ordination of sample locations based on the matrix constructed using 14 variables (geochemical elements).

\section{Results}

\subsection{Grain size, geochemical composition, and trace metal contents}

Sediments of core 11257 were composed mainly of homogeneous mud facies with 68.84\% clay and 30.02\% silt (Table 1,

25 Figure 2-A). The OM content averaged 7.25\% with a range from 6.53 to $8.29 \%$ (Table 1 ). The TOC and TN content averaged $0.9 \%$ and $0.15 \%$ with ranges from 0.77 to $1.08 \%$ and 0.08 to $0.20 \%$, respectively (Table 1 ), and both gradually increased from the lowermost to the uppermost layers of the cores (Figure 2-B, C). The TS content, pH, carbon-to-nitrogen ratio (C/N), and carbon-to-sulfur ratio (C/S) averaged $0.15 \%, 6.97,6.05$, and 6.33 with ranges of 0.08-0.22\%, 6.75-7.24, 5.03-10.49, and 4.41-12.12, respectively (Table 1). The average concentrations of the trace metals in core 11257 were below the ER-L values, 30 except for Ni with a concentration of $23.5 \mathrm{mg} / \mathrm{kg}$ (Table 1). The concentration of Mn, Zn, Pb, and Cu, $468.9 \mathrm{mg} / \mathrm{kg}, 52.9$ 
Biogeosciences Discuss., https://doi.org/10.5194/bg-2017-383

Manuscript under review for journal Biogeosciences

Discussion started: 1 November 2017

(c) Author(s) 2017. CC BY 4.0 License.

$\mathrm{mg} / \mathrm{kg}, 15.8 \mathrm{mg} / \mathrm{k}$ and $0.07 \mathrm{mg} / \mathrm{kg}$ on average, respectively, increased slightly from the lowermost to the uppermost layers (Figure 2-E H).

Sediments of core 10863 were composed mainly of homogeneous mud facies with $66.10 \%$ clay and 33.25\% silt (Table 2, Figure 2-I). The OM content, TS content, $\mathrm{pH}$, and $\mathrm{C} / \mathrm{N}$ averaged 7.62\%, 0.26\%, 6.94, and 5.44 with ranges of 6.74-8.69\%,

$5 \quad 0.19-0.3 \%, 6.74-7.13$, and 4.82-6.13, respectively (Table 2). The TOC and TN content averaged 1.07\% (range, 0.82-1.27\%) and $0.2 \%$ (range, $0.15-0.26 \%$ ), respectively, and increased gradually from the lower layers of the core upward (Figure 2-J, K). However, the TOC content increased rapidly from a depth of $21 \mathrm{~cm}$ and appeared to remain constantly to the uppermost layer (1.22\% on average). The C/S averaged 4.16, and was mostly distributed between 3.0 and 5.0 (Table 2). The average concentrations of the trace metals in core 10863 were below the ER-L values, except for Ni with a concentration of $23.4 \mathrm{mg} / \mathrm{kg}$

10 (Table 2). The concentration of $\mathrm{Mn}, \mathrm{Zn}, \mathrm{Pb}$, and $\mathrm{CU}$ averaged $517.1 \mathrm{mg} / \mathrm{kg}, 76.1 \mathrm{mg} / \mathrm{kg}, 17.5 \mathrm{mg} / \mathrm{k}$, and $0.09 \mathrm{mg} / \mathrm{kg}$, respectively, and increased slightly from the lowermost to the uppermost layers (Figure 2-M P).

Sediments of core 11285 were mainly composed of homogeneous mud facies with 66.95\% clay and 32.64\% silt (Table 2, Figure 2-Q). The OM, TOC, TN and TS content averaged 8.76\%, 1.07\%, 0.28\%, and $0.46 \%$ with ranges of 8.1-10.26\%, 0.96$1.29 \%, 0.24-0.35 \%$, and $0.32-0.62 \%$, respectively, and the $\mathrm{C} / \mathrm{N}$, with an average value of 3.86, ranged from and 3.30 to 4.47

15 (Table 3). The C/S averaged 2.36 and ranged from 1.85 to 3.08; these values were generally below 3.0 throughout the core, except in the layers at depths of $5 \mathrm{~cm}, 57 \mathrm{~cm}$, and $59 \mathrm{~cm}$ (Table 3). The C/S values declined from the lowest layer (3.07) to the layer at $39 \mathrm{~cm}$ of depth (2.02) (Figure 2-T), and maintained an average concentration of 2.10 until $7 \mathrm{~cm}$ in depth, although the TOC and TN content did not show distinct corresponding variations (Figure 2-R, S). For trace metal concentrations, Ni, with an average of $24.1 \mathrm{mg} / \mathrm{kg}$, was the only metal to exceed its ER-L value, and the average concentrations of the remaining metals

20 were all below the corresponding ER-L (Table 3) values. Variations in concentrations of the trace metals $\mathrm{Mn}, \mathrm{Zn}, \mathrm{Pb}, \mathrm{and} \mathrm{Cu}$ appeared at $37 \mathrm{~cm}$ in depth with a relatively broad distribution (Figure 2-U X). The concentration of Mn, which averaged $560.57 \mathrm{mg} / \mathrm{kg}$, decreased distinctly from the lowest layers $(705.20 \mathrm{mg} / \mathrm{kg})$ to a depth of $27 \mathrm{~cm}(434.80 \mathrm{mg} / \mathrm{kg})$ and appeared constant from that level to the uppermost layer $(485.77 \mathrm{mg} / \mathrm{kg}$ ) (Figure 2-U). Concentrations of Zn, which averaged 99.39 $\mathrm{mg} / \mathrm{kg}$ overall, varied at $37 \mathrm{~cm}$ of depth from an average of $93.18 \mathrm{mg} / \mathrm{kg}$ to an average of $102.98 \mathrm{mg} / \mathrm{kg}$.

\section{$25 \quad 4.2$ Benthic foraminifera}

Sixty-six species of benthic foraminifera (four agglutinated, 56 calcareous-hyaline, and six calcareous-porcelaneous) belonging to 43 genera were identified from sediments of core 11257 (Appendix A). The abundance frequency of agglutinated foraminifera, $7.7 \%$ on average, gradually increased from the lowermost to the uppermost layers (Figure 3-I-A). The dominant species (over 10\% of abundant frequency in one layer) of benthic foraminifera, out of an average total of 6,608 individual

30 benthic foraminifera in $20 \mathrm{ml}$ of sediment, were Ammonia beccarii (average: 14.0\%), Elphidium advenum (average: 13.3\%), E. clavatum (average: 13.1\%), E. subarcticum (average: 12.4\%) and A. ketienziensis (average: 6.5\%). Therefore, the abundance frequencies among these dominant species differs very little. Variations in the abundance frequencies of these dominant species 
Biogeosciences Discuss., https://doi.org/10.5194/bg-2017-383

Manuscript under review for journal Biogeosciences

Discussion started: 1 November 2017

(c) Author(s) 2017. CC BY 4.0 License.

showed no clear trends from the lowermost to the uppermost layers (Figure 3-I-B F), and the species diversity was high with an average value of 2.8 and a range from 2.6 to 2.9, indicating no clear trends in variation. The total number of benthic foraminifera (TNBF) decreased gradually from the lowest layer (8,016 individuals) to $11 \mathrm{~cm}$ (4,288 individuals) and increased again to $5 \mathrm{~cm}$ (11,296 individuals) (Figure 3-I-H). A cluster analysis was conducted using the Bray-Curtis similarity index (SI) to examine the similarities among the component species at each location in which benthic foraminifera were found in any given sample (Figure 4-A). Twenty samples were categorized into one cluster with similarity (SI) $\approx 74.51$. Cluster I was composed of an A. beccarii-E. advenum-E. clavatum (Ab-Ea-Ec) assemblage.

Fifty-six species of benthic foraminifera (four agglutinated, 46 calcareous-hyaline, and 6 calcareous-porcelaneous) belonging to 39 genera were identified from sediments of core 10863 (Appendix B). The dominant species of benthic foraminifera, out of a total average of 2,544 individual benthic foraminifera in $20 \mathrm{ml}$ of sediment, were E. subarcticum (average: 20.9\%), A. beccarii (average: 14.9\%), E. clavatum (average: 12.5\%), E. advenum (average: 11.8\%) and A. ketienziensis (average 6.5\%). Co-occurring species were E. somaense (average: 5.2\%) and B. frigida (average: 3.8\%). The abundance frequency of E. subarcticum sharply increased from $17 \mathrm{~cm}$ depth toward the uppermost layers (Figure 3-II-F), although the frequencies of $A$. beccarii, A. ketienziensis, E. advenum and E. clavatum showed no clear variation (Figure 3-II-B E). Species diversity averaged

152.5 and gradually decreased from the $17 \mathrm{~cm}$ depth to the uppermost layer (Figure 3-II-G). The TNBF increased gradually from the lowermost layer (3,816 individuals) to the uppermost layer (1,920 individuals) (Figure 3-II-H). Based on the cluster analysis, twenty-two samples were categorized into two clusters with SI $\approx 72.0$ (Figure 4-B). Cluster I, which consisted of samples from 0-17 cm core depth, was an E. subarcticum-A. beccarii (Es-Ab) assemblage with average abundance frequencies of 30.2-42.6\% and 9.6-22.0\%, respectively. Cluster II, which consisted of samples from 19-43 cm core depth, was an A.

20 beccarii-E. advenum-E. clavatum (Ab-Ea-Ec) assemblage with average abundance frequencies of $14.5 \%, 14.3 \%$ and $14.2 \%$, respectively, notably with very little difference among these abundance frequencies.

Twenty-seven species (five agglutinated, 20 calcareous-hyaline, and two calcareous-porcelaneous) belonging to 22 genera were identified from sediments of core 11285 (Appendix C). The abundance frequency of agglutinated species averaged 13.3\%, and these taxa consisted mainly of Eggerella advena and Trochammina hadai, and gradually increased in abundance from 39 cm depth to the uppermost layer (Figure 3-III-A). The dominant species were E. subarcticum (average: 31.8\%), A. beccarii (average: 27.4\%), B. frigida (average: 15.6\%), T. hadai (average: 10.8\%), E. advenum (average: 5.3\%), E. somaense (average: 5.3\%), Eg. advena (average: 4.0\%) and E. clavatum (average: 3.5\%). The abundance frequency of E. subarcticum, the most dominant species, rapidly increased from $27 \mathrm{~cm}$ depth to the uppermost layer (Figure 3-III-I). In contrast, the abundance frequencies of $A$. beccarii (Figure 3-III-D) and E. advenum (Figure 3-III-F) rapidly decreased upward from 41 and $45 \mathrm{~cm}$ 30 depth, respectively. The abundance frequency of T. hadai increased from $39 \mathrm{~cm}$ depth to the uppermost layer (Figure 3-III-C). The species diversity was very low with an average value of 1.5, and it showed no distinct variation pattern (Figure 3-III-J). The TNBF, with an average of 548 individuals, decreased gradually from the lowermost layer (1,160 individuals) to 11 cm depth (80 individuals), and reached its highest value (2,682 individuals) at $7 \mathrm{~cm}$ of depth (Figure 3-III-K). 
Biogeosciences Discuss., https://doi.org/10.5194/bg-2017-383

Manuscript under review for journal Biogeosciences

Discussion started: 1 November 2017

(c) Author(s) 2017. CC BY 4.0 License.

In the results of the cluster analysis, 30 samples were categorized into three clusters with SI $\approx 62.56$ (Figure 4-C). Cluster I, which consisted of only the sample from $35 \mathrm{~cm}$ depth was a B. frigida-A. beccarii-E. subarcticum (Bf-Ab-Es) assemblage with average abundance frequencies of 21.9\%, 17.1\% and 11.6\%, respectively. Cluster II was composed of three sub-cluster (IIa, $\mathrm{IIb}$, and IIc) with $\mathrm{SI} \approx 72.77$ (Figure 4-C). Cluster IIa consisted of samples from 11-15 cm and $29 \mathrm{~cm}$ depth (IIa1) as well as samples from $39 \mathrm{~cm}$ and $41 \mathrm{~cm}$ depth (IIa2), with SI $\approx 74.0$ (Figure 4-C). Cluster IIa1 was an A. beccarii-E. subarcticum-T. hadai (Ab-Es-Th) assemblage with abundance frequencies of 32.8\%, 23.1\% and 9.9\%, respectively. Cluster IIa2 was an $E$. somaense-A. beccarii-B. frigida (Eso-Ab-Bf) assemblage with abundance frequencies of $23.7 \%, 20.7 \%$ and $19.9 \%$, respectively. Cluster IIb, which was composed of samples from 31 and $33 \mathrm{~cm}$ depth, was a T. hadai-E. subarcticum-B. frigida (Th-Es-Bf) assemblage with abundance frequencies of 33.3\%, 20.8\% and 19\%, respectively. Cluster IIc consisted of samples from 1-9 cm and 15-27 cm depth and was an E. subarcticum (Es) assemblage with an average abundance frequency of 64.9\% (range: 46.1-74.3\%). Cluster III consisted of samples from $37 \mathrm{~cm}$ and $43-59 \mathrm{~cm}$ depth, and was an A. beccarii-B. frigida-E. advenum (Ab-Bf-Ea) assemblage average abundance frequencies of $49.2 \%, 20.8 \%$ and $9.5 \%$, respectively.

\section{$4.3^{210} \mathrm{~Pb}$ ages of core sediments}

The total ${ }^{210} \mathrm{~Pb}$ in the sediments of cores 11257,10863 and 11285 ranged from 17.2 to $64.7 \mathrm{mBq} / \mathrm{g}, 20.2$ to $89.7 \mathrm{mBq} / \mathrm{g}$ and $\mathrm{mBq} / \mathrm{g}$ to $99.5 \mathrm{mBq} / \mathrm{g}$, respectively (Table 4). The excess or unsupported ${ }^{210} \mathrm{~Pb}$ values were determined by subtracting the supported ${ }^{210} \mathrm{~Pb}$ (according to the asymptotic value) from the total ${ }^{210} \mathrm{~Pb}$ measured at each depth. Excess ${ }^{210} \mathrm{~Pb}$ did not decline exponentially downward in the cores, and the highest ${ }^{210} \mathrm{~Pb}$ values of cores 10863 and 11285 were found at depths of $3 \mathrm{~cm}$ and $7 \mathrm{~cm}$, respectively. These findings suggest that the sediment accumulation rates vary over time. Alternatively, the erratic distribution of ${ }^{210} \mathrm{~Pb}$ concentrations may be attributed to biological mixing. The constant rate of supply (CRS) model, commonly used to derive ${ }^{210} \mathrm{~Pb}$ dates, was used to calculate sediment ages and sedimentation rates (Appleby and Oldfield, 1992). Based on the results of the CRS model, sediments of core 11257, 10863 and 11285 were approximately dated to the years 1908 (thickness: $40 \mathrm{~cm}$ ), 1904 (thickness: $44 \mathrm{~cm}$ ) and 1906 (thickness: $60 \mathrm{~cm}$ ), respectively (Table 4). The uppermost limit of the sedimentation period, which was about 2014, was established, and the lowest limit was set to about 1904 based on the half-life (22.3 years) of ${ }^{210} \mathrm{~Pb}$ (Sanchez-Cabeza and Ruiz-Fernandez, 2012) to ensure the accuracy of data acquired during the sedimentation periods of the three cores. The sedimentation rate of the core 11257 averaged $0.44 \mathrm{~cm} / \mathrm{year}$ with a range from 0.31 to $0.84 \mathrm{~cm} /$ year, and it increased very slowly upward (Figure 5-A). The sedimentation rate of core 10863 averaged $0.60 \mathrm{~cm} /$ year with a range from 0.34 to $1.71 \mathrm{~cm} /$ year, and it increased gradually after 1990 (Figure 5-B). The sedimentation rate of core 11285 averaged $1.19 \mathrm{~cm} /$ year with a range from 0.41 to $4.40 \mathrm{~cm} /$ year, and it increased rapidly after 1960 (Figure $5-C)$.

\section{Discussion}


Biogeosciences Discuss., https://doi.org/10.5194/bg-2017-383

Manuscript under review for journal Biogeosciences

Discussion started: 1 November 2017

(c) Author(s) 2017. CC BY 4.0 License.

Sediments composed of homogeneous fine-grained mud facies with 30.02-33.25\% silt and 66.10-68.84\% clay accumulated in cores 11257 (western area), 10863 (eastern area), and 11285 (northwestern area) over about 110 years. These sediments, however, show mutually distinct differences in the variation profiles of the concentrations of trace metals and geochemical elements, as well as in statistical data of benthic foraminiferal assemblages (Tables 1, 2 and 3, Figs. 2 and 3). In particular, the difference was more definite in the comparison of benthic foraminiferal assemblage in the three stations (Figs. 4 and 6 ). The western and eastern areas are respectively characterized by only one benthic foraminiferal assemblage, the Ab-Ea-Ec assemblage (Figure 6-A), and two benthic foraminiferal assemblages, the Ab-Ea-Ec assemblage (lower layers, 44-18 cm) and the Es-Ab assemblage (upper layers, 18-0 cm) (Figure 6-B). However, the benthic foraminiferal assemblage of the northwestern area progressed from an Ab-Bf-Ea assemblage in the lowermost layers to an Eso-Ab-Bf assemblage, Ab-Bf-Ea assemblage, Bf-Ab-Es assemblage, Th-Es-Bf assemblage, Ab-Es-Th assemblage, and finally to Es assemblage in the uppermost layers (Figure 6-C). It may be appropriate to use the records of the northwestern area, which exhibits variation in the foraminiferal assemblages and geochemical elements, as the standard for variation in the pollution history of Gamak Bay over the last 110 years.

\subsection{The pre-urbanization period}

15 The Ab-Bf-Ea assemblage, which was deposited between 1906 and 1964 in the northwestern area is characterized by a high abundance frequency of $A$. beccarii with 49.2\% (Figure 3-III-Zone A, Figure 6-C), and correlated with the Ab-Ea-Ec assemblage of lower layers (deposited between 1904 and 1988) in the eastern area (Figure 6-B) and the Ab-Ea-Ec assemblage (deposited between 1908 and 2014) of the western area (Figure 6-A). A. beccarii, which is a principal dominant species in all three areas, is broadly distributed around the inner bay, tidal flats, brackish-water environments of the Pacific Ocean (Murray, 1991; Alve and Murray, 1999; Hayward et al., 2004; Murray 2006), and the brackish coastal areas of the East China Sea and Huanghai (Yellow) Sea (Wang et al., 1985), as well as in Gyunggi Bay and Ansan Bay in South Korea (Chang and Lee, 1984; Woo and Lee, 2006). B. frigida, E. advenum and E. clavatum are widely distributed around the southern and western coastal areas of Korea (Woo and Lee, 2006; Lee et al., 2016). Lee et al. (2016) reported that E. advenum was positively correlated to dissolved oxygen, $\mathrm{pH}$, and $\mathrm{C} / \mathrm{S}$ in sediments of Gamak Bay. Therefore, this dominance in this taxon does not appear to be distinct to the pollution phenomenon described herein. However, statistical data from benthic foraminifera with a species diversity of 1.37 and a TNBF of 704 individuals in the northwestern area indicates a progression in the degree of pollution in the sediment (Alve, 1995) compared to the eastern area with a TNBF of 3.068 individuals, a species diversity of 2.67, and western area with a TNBF of 6,608 individuals with species diversity of 2.8. C/S ratios greater than 5, between 3 and 5, and less than 3 indicate freshwater conditions, oxic marine-to-brackish conditions, and reductive brackish marine conditions, respectively (Berner and Raiswell, 1984). The northwestern area with a C/S of 2.63 may be a somewhat brackish environment compared to the eastern area with a C/S of 3.73 and western area with a C/S of 6.33. 
Biogeosciences Discuss., https://doi.org/10.5194/bg-2017-383

Manuscript under review for journal Biogeosciences

Discussion started: 1 November 2017

(c) Author(s) 2017. CC BY 4.0 License.

The Korean coastal zones began to undergo an urbanization in earnest in the 1910s with an increase in fossil fuel (especially coal) consumption (Jeong et al., 2006; Lim et al., 2012, 2013). Therefore, pollution or a reductive brackish environment in the northwestern area, even though there were no differences in species composition of benthic foraminifera, may be caused by stagnant sewage supplied from a small village that formed before city construction in the hinterland of the northwestern area, and the oval-shaped bottom topography of northwestern area, as shown from the difference of the sedimentation rate between northwestern $(0.64 \mathrm{~cm} / \mathrm{y})$ and eastern $(0.42 \mathrm{c} \mathrm{m} / \mathrm{y})$, western $(0.44 \mathrm{~cm} / \mathrm{y})$ area.

\subsection{Urbanization period}

Benthic foraminiferal assemblage in the northwestern area varied rapidly from the Eso-Ab-Bf assemblage, through Ab-Bf-Ea, Bf-Ab-Es, Th-Es-Bf, to Ab-Es-Th assemblage in a brief space of time between 1965 and 1987. The abundance frequency of

10 T. hadai, E. somaense and E. subarcticum increased compared to that during the pre-urbanization period, but A. beccarii decreased, and B. frigida did not show a remarkable variation (Figure 3-III-Zone B). This period is characterized by an increase in the E. subarcticum, which is known as a bioindicator of organic pollution in Gamak Bay, with a DO content of 0.4 mg/L at oxygen minimum zones (OMZs: Helly and Levin, 2004; Paulmier and Ruiz-Pino, 2008) (Lee et al., 2016) and agglutinated species including T. hadai, which increase in abundance under eutrophic conditions. The representative foraminiferal

15 assemblages from hypoxic sediments associated with eutrophication have been found in Osaka Bay, Japan (Tsujimoto et al., 2006a, 2006b, 2008) and Gamak Bay, South Korea (Lee et al., 2012, 2016). During deposition of this interval, the sedimentation rate was higher than that during the pre-urbanization period, i.e., $1.0 \mathrm{~cm} /$ year versus $0.64 \mathrm{~cm} / \mathrm{year}$, and $\mathrm{C} / \mathrm{S}$ decreased from 2.63 to 2.08. TNBF decreased relative to the pre-urbanization period from 704 to 244 individuals. Statistic indices of geochemical and benthic foraminiferal assemblages still indicate unfavorable sediment and environmental conditions. A rapid variation in the benthic foraminiferal assemblages may reflect the unstable habitat environment that was caused by continuous inflow and deposition of sewage into sediment, as shown with an increase in the abundance frequency in T. hadai and E. subarcticum.

This sewage is thought to have caused eutrophication, and the water quality deteriorated more than during the pre-urbanization period. These conditions may have been caused by the increase in sewage discharged from Yeosu City, which was constructed

25 at the hinterland of northernmost area in Gamak Bay for people employed at the Yeocheon Industrial Complex from the late 1960s to the early 1970s (Kim et al., 2014).

The dense population and associated rapid urbanization that emerged in the 1960s resulted in great ecological stresses affecting the coastal ecosystems along the Korean coast (Choi et al., 2010). No benthic foraminiferal assemblages in the eastern and western areas of the bay correlate with the Eso-Ab-Bf $\sim$ Ab-Es-Th assemblages of the northwestern area, and these findings suggest that pollution during the urbanization period may have been restricted to the northwestern area and to not diffuse to the surrounding area (Figure 6-C). 
Biogeosciences Discuss., https://doi.org/10.5194/bg-2017-383

Manuscript under review for journal Biogeosciences

Discussion started: 1 November 2017

(c) Author(s) 2017. CC BY 4.0 License.

\subsection{The aquaculture period}

The Es, Ab-Es-Th and Es assemblages were sequentially distributed in the northwestern area (Figure 6-C) from 1988 to 2014 , and these are characterized by a high abundance frequency of E. subarcticum (Figure 3-III-Zone C). The Es assemblage in sediments deposited between 1988 and 2002 is composed mostly of E. subarcticum with an average abundance frequency of

5 55.2\%, which is a bioindicator of organic pollution in Gamak Bay. The high sedimentation rate in this period, $1.54 \mathrm{~cm} / \mathrm{year}$, must be noted. The northwestern area of Gamak Bay has been a primary site for suspended mussel farming (Mytilus galloprovincialis) since the 1980s. Mussel farms can produce biodeposits such as feces and pseudofeces at rates that reach 3000 metric tons $\cdot \mathrm{ha}^{-1} \cdot \mathrm{year}^{-1}$ (Grenz, 1989), as well as shell parts that build up at a rate of $10 \mathrm{~cm} \cdot \mathrm{year}^{-1}$, resulting in changes to the seabed approximately 20 m from a farm’s boundaries (Dählback and Gunnarsson, 1981; Matisson and Lindén, 1983).

10 Sedimentation rates were greater within the farm than at reference sites, which supports the theory that mussel farming increases sedimentation rates (Callier et al., 2006). Therefore, the high sedimentation rate may be mostly the result of mussel farming. It is widely accepted that the primary benthic environmental impact of suspended mussel farming is the buildup of biodeposits directly below the culture area (Jaramillo et al., 1992; Hargrave, 2003), which may cause negative effects on the coastal systems, such as eutrophication and hypoxia, which occur at $<0.2 \mathrm{mg} \cdot \mathrm{L}^{-1}$ or $\mathrm{mL} \cdot \mathrm{L}^{-1} \mathrm{O}_{2}$ (Rabalais et al., 1991; Breitburg

15 et al., 2001; Diaz and Rosenberg, 2008; Doney, 2010; Gilbert et al., 2010; Kalantzi et al., 2013). The TNBF of 265 individuals/year, species diversity of 1.24 and C/S of 2.12 indicate worsening of benthic ecology and the sedimentary environment during this period associated with mussel farming.

The Ab-Es-Th assemblage distributed between 2003 and 2007 is composed of A. beccarii (abundance frequency: 35.2\%), E. subarcticum (abundance frequency: 19.3\%), T. hadai (abundance frequency: 17.1\%), and has a TNBF of 99 individuals, 20 species diversity of $1.77, \mathrm{C} / \mathrm{S}$ of 2.10 and a sedimentation rate of $1.54 \mathrm{~cm} /$ year (Figure 6-C). During this period, statistical indices of benthic foraminifera and geochemical data indicate the deterioration of the benthic environment similar to the Es assemblage between 1988 and 2002. However, the difference in species composition between these two periods is associated with a rapid increase in the abundance frequency of A. beccarii, which is a common species in the inner bay. This difference may have been caused by an improvement in the benthic environment via dredging of the polluted sediment within the mussel

25 farm, which was conducted as part of the "Establishment of action plans for model coastal environmental management areas" (Ministry of Oceans and Fisheries, 2001).

The benthic foraminiferal assemblage varied to Es assemblage again after 2008 to 2014, which is composed mostly of $E$. subarcticum, with an average abundance frequency of $62.6 \%$, TNBF of 1,323 individuals/year, species diversity of 1.23, C/S of 2.71 and a sedimentation rate of $3.15 \mathrm{~cm} /$ year (Figure 6-C). This interval has the highest abundance frequency of $E$. subarcticum and TNBF after 1987. The abundance frequency of $A$. beccarii was the highest in the pre-pollution period, and it subsequently decreased rapidly. Conversely, the E. subarcticum abundance increased rapidly and reached its highest frequency during the aquaculture period (Figure 3-III-D, I). As the pollution increased, the populations of transitional or more tolerant species increased at the expense of taxa that are more sensitive, and highly tolerant or opportunistic species ultimately become 
Biogeosciences Discuss., https://doi.org/10.5194/bg-2017-383

Manuscript under review for journal Biogeosciences

Discussion started: 1 November 2017

(c) Author(s) 2017. CC BY 4.0 License.

dominant (Alve, 1995). It is thought that organic pollution in the northwestern area of Gamak Bay progresses rapidly through a high sedimentation (rate: $3.15 \mathrm{~cm} /$ year) of biodeposits discharged from the suspended mussel farm. These polluted materials accumulated in sediment may contribute to the continuous deterioration and variation in the benthic ecological environment by means of “pollution storage,” although these materials may be partially removed by residual bottom currents (Lee et al., 5 2016).

The Es, Ab-Es-Th and Es assemblages of the northwestern area are correlated with the Es-Ab assemblage of the eastern area where oyster farming took place between 1989 and 2014. The latter assemblage is composed of E. subarcticum (35.4\%) and A. beccarii (15.5\%) and has a TNBF of 1787 individuals, species diversity of 2.18, C/S of 4.8 and a sedimentation rate of 0.95 $\mathrm{cm} /$ year (Figure 6-B). The environment conditions of the benthic ecology in the eastern area appear to have been better than

10 those in the northwestern area, although oyster farming also affects sedimentation and associated infaunal assemblages beneath cultivation areas (De Grave et al., 1998; Kaiser et al., 1998; Forrest and Creese, 2006; Dubois et al., 2007; Forrest et al., 2009; Solomon and Ahmed, 2016). In shallow-water eutrophic systems, the temporal and spatial changes in benthic foraminifera appear to be controlled primarily by the timing and extent of organic matter flux (Sabbatini et al., 2012). Organic matter in surface sediment is an important source of food for benthic fauna, but an overabundance may lead to a reduction in species

15 richness, abundance and biomass because of oxygen depletion and buildup of toxic byproducts, which may lead to an anaerobic and ultimately azoic state in heavily farmed or depositional areas; remediation of highly enriched sediments may take several years (Pereira et al., 2004). In addition, the extent of the environmental impact of the aquaculture depends on the amount of nutrients and organic matter that is released as well as on the hydrodynamic processes, including waves, current activity, and water residence time (Ackefors and Enell, 1994; Wu, 1995; Aure et al., 2007; Duarte et al., 2008; Stevens et al., 2008;

20 Strohmeier et al., 2008). Ultimately, polluted sediment in the northwestern area may be caused by overabundance and excessive deposition of organic matter through over-supply from mussel farming as well as the oval-shaped bottom physiography and very slow current speed (Lee et al., 2009), even though the species composition is somewhat similar between northwestern and eastern areas.

During the transition from the pre-urbanization to the urbanization period and aquaculture period, the concentration of Mn

25 (average: $560.57 \mathrm{mg} / \mathrm{kg}$ ) in the northwestern area rapidly decreased from the lowermost layer (705.2 mg/kg) to the layer at 25 cm depth (431.0 mg/kg) and uppermost layer (470.2 mg/kg) (Figure 2-U), in contrast to gradually increasing values in the eastern and western area (Figure 2-E, M). This prominent upward decrease in Mn content is ascribed to its higher mobility than Fe and S with redox change during anoxic sediment diagenesis (Emerson et al., 1979; Kersten and Forstner, 1986; Calvert and Pederson, 1993). Lee et al. (2016) suggested that extremely polluted reducing conditions with a high OM content (>12.0\%) and OMZs with dissolved oxygen (DO) $<0.4 \mathrm{mg} \cdot \mathrm{L}^{-1}$ formed below the mussel farms in the northwestern area of Gamak Bay, and that these conditions are associated with the appearance of E. subarcticum as a bioindicator. The processes of variation in benthic foraminiferal assemblages from the Ab-Bf-Ea assemblage, through Eso-Ab-Bf, Ab-Bf-Ea, Bf-Ab-Es, Th-Es-Bf, to 
Biogeosciences Discuss., https://doi.org/10.5194/bg-2017-383

Manuscript under review for journal Biogeosciences

Discussion started: 1 November 2017

(c) Author(s) 2017. CC BY 4.0 License.

Ab-Es-Th assemblages and ultimately to the Es assemblage may represent the transition from oxic to anoxic environmental conditions.

\subsection{Pollution variation}

The organic matter discussed in the present study plays an important role in controlling the composition of benthic foraminiferal assemblages. The OM content and quality can be considered an important limiting factor for foraminiferal development (Armynot du Chátelet et al., 2008), as indicated by the TOC content and the quality of the organic matter represented by the C/N ratio (Foster et al., 2012). A PCA and scatter diagram analysis was conducted to identify the relationships between the foraminiferal assemblages and geochemical characteristics (Figure 7), and the variations between the sampling depth and pollution intensity (Figure 8), respectively. The TOC content of core 11257 does not show a distinct relationship and trend in PCA (Figure 7-A) and in the scatter diagram analysis (Figure 8-A). However, the TOC content of core 10863 has positive relationship with E. subarcticum and negative relationships with E. advenum, E. clavatum and species diversity (Figure 7-B). These results show a distinct pollution phenomenon from Group I sediments of 43-23 cm depth toward Group II sediments of 21-1 cm of depth and an Es-Ab assemblage (Figure 8-B). The TOC content of core 11285 has positive relationship with E. subarcticum, E. advena and T. hadai, and negative relationship with A. beccarii, E. advenum, E. clavatum and Mn (Figure 7-C). It varies in three phase from Group I to Group III in scatter diagram analysis (Figure 8-C). Group I consists of sediments from 59-47 cm depth, group II of sediments from 43-33 cm depth, and group III of sediments from of 29-1 cm (except of $23 \mathrm{~cm}$ ) depth, which indicate the variation from the pre-urbanization period to the urbanization period, and the aquaculture period.

\section{Conclusion}

20 Historical records of the effects of anthropogenic pollution on the benthic foraminifera over the last 110 years in Gamak Bay are summarized in Figure 9 based on three periods. In the period between 1906 and 1964, Gamak Bay may have remained mostly unpolluted by anthropogenic activities, which allowed the Ab-Ea-Ec assemblage to flourish, except in the northwestern area with Ab-Bf-Ea assemblage that gradually deteriorated under the effects of a concave bottom physiography, flux limited sea water movement and sewage flux from small streams of villages (Figure 9-A). With city construction for people employed at the industrial complex between 1965 and 1987, the sewage inflow into the northwestern area increased rapidly, the pollution continuously accelerated, and the benthic foraminiferal assemblage rapidly progressed from Eso-Ab-Bf assemblage, through Ab-Bf-Ea, Bf-Ab-Es, Th-Es-Bf, to Ab-Es-Th assemblage in a brief space of time (Figure 9-B) via unstable habitat conditions. Pollution during the urbanization period may have been contained within the northwestern area, and it did not diffuse to the surrounding area. However, the northwestern area between 1988 and 2014 became progressively intensified by sewage flux and mussel farming in, and the organic pollution rapidly increased by a high sedimentation of the biodeposits (Figure 9-C). 
Biogeosciences Discuss., https://doi.org/10.5194/bg-2017-383

Manuscript under review for journal Biogeosciences

Discussion started: 1 November 2017

(c) Author(s) 2017. CC BY 4.0 License.

The benthic foraminiferal assemblage transitioned into an Es assemblage composed of E. subarcticum, known to the bioindicator of organic pollution in Gamak Bay. These processes of variation in benthic foraminiferal assemblages at northwestern area may represent the transition from oxic to anoxic environmental conditions. During this period, pollution extended to the eastern area which affected oyster farming, causing a shift to an Es-Ab assemblage (Figure 9-C). The western area, however, was unpolluted over the last 110 years due to the clockwise movement of the sea water inflow from the bay mouth of the south. The western area is considered to show reference conditions of Gamak Bay for both environmental parameters and foraminiferal assemblages.

\section{Acknowledgements}

This research was supported by the Basic Science Research Program through the National Research Foundation of Korea

10 (NRF), funded by the Ministry of Science, ICT \& Future Planning (NRF-2017R1A2B1006247). This work was also supported by grants from the National Institute of Fisheries Science (R2017048). This research was also supported by the Golden Seed Project, Ministry of Agriculture, Food and Rural Affairs (MAFRA), Ministry of Oceans and Fisheries (MOF), Rural Development Administration (RDA), and Korea Forest Service (KFS).

\section{References}

15 Ackefors, H. and Enell, M.: The release of nutrients and organic matter from aquaculture systems in Nordic countries, J. Appl. Ichthyol., 10, 225-241, 1994.

Asano, K.: Illustrated Catalogue of Japanese Tertiary smaller Foraminifera, Part 1: Nonionidae, Hosokawa Printing Co, Tokyo, Japan, 12 pp., 1950.

Asano, K.: Illustrated Catalogue of Japanese Tertiary smaller Foraminifera, Part 6: Miliolidae, Hosokawa Printing Co, Tokyo,

20 Japan, 20 pp, 1951a.

Asano, K.: Illustrated Catalogue of Japanese Tertiary smaller Foraminifera, Part 14: Rotaliidae, Hosokawa Printing Co, Tokyo, Japan, 21 pp, 1951b.

Asano, K.: Illustrated Catalogue of Japanese Tertiary smaller Foraminifera, Supplement. No. 1, Hosokawa Printing Co, Tokyo, Japan, 17 pp, 1952.

25 Alve, E.: Benthic foraminiferal responses to estuarine pollution: a review, J. Foraminifer Res., 25, 190-203, 1995.

Alve, E., Lepland, A., Magnusson, J., and Backer-Owe, K.: Monitoring strategies for re-establishment of ecological reference conditions: possibilities and limitations, Mar. Pollut. Bull., 59, 297-310, 2009.

Alve, E. and Murray, J.W.: Marginal marine environments of the Skagerrak and Kattegat: a baseline study of living (stained) benthic foraminiferal ecology, Palaeogeogr Palaeocl., 146, 171-193, 1999. 
Biogeosciences Discuss., https://doi.org/10.5194/bg-2017-383

Manuscript under review for journal Biogeosciences

Discussion started: 1 November 2017

(c) Author(s) 2017. CC BY 4.0 License.

Armynot du Chátelet, E., Recourt, P., and Chopin, V.: Mineralogy of agglutinated benthic foraminifera; implications for paleoenvironmental reconstructions. Bull. Soc. Geol. Fr., 179, 583-592, 2008.

Appleby, P.G. and Oldfield, F.: Applications of lead-210 to sedimentation studies. in: Uranium-Series Disequilibrium: Applications to Earth and Marine, and Environmental Problems, Ivanovich, M. and Harmon, R.S. (Eds.),. Clarendon Press, 5 Oxford, Uk, 731-778, 1992.

Aure, J., Strohmeier, T., and Strand, Ø.: Modelling current speed and carrying capacity in long-line blue mussel (Mytilus edulis) farms, Aquac. Res., 38, 304-312, 2007.

Barras, C., Jorissen, F.J., Labrune, C., Andral, B., and Boissery, P.: Live benthic foraminiferal faunas from the French Mediterranean Coast: Towards a new biotic index of environmental quality, Ecol. Indic., 36, 719-743, 2014.

10 Berner, R.A. and Raiswell, R.: C/S method for distinguishing fresh water from marine sedimentary rocks, Geology, 12, 365368, 1984.

Breitburg, D.L., Pihl, L., and Kolesar, S.E.: Effects of low dissolved oxygen on the behavior, ecology and harvest of fishes: A comparison of the Chesapeake Bay and Baltic-Kattegat systems, in: Coastal Hypoxia: Consequences of Living Resources and Ecosystems, Rabalais, N.N. and Turner, R.E. (Eds.), American Geophysical Union, Washington, D.C., 241-268, 2001.

15 Callender, E.: Heavy metals in the environment-historical trends, in: Environmental Ggochemistry, Lollar, B.S. (Eds.), in: Treatise on Geochemistry, Holland, H.D. and Turekian, K.K. (Eds.), Elsevier Science, Oxford, 67-105, 2003.

Callier, M.D., Weise. A.M., McKindsey, C.W. and Desrosiers, G.: Sedimentation rates in a suspended mussel farm (GreatEntry Lagoon, Canada): biodeposit production and dispersion. Mar. Ecol.-Prog. Ser., 322, 129-141, 2006.

Calvert, S.E. and Pederson, T.F.: Geochemistry of recent oxic and anoxic marine sediments: Implications for the geological 20 record. Mar. Geol., 113, 67-88, 1993.

Cantwell, M.G., King, J.W., Burgess, R.M., and Appleby, P.G.: Reconstruction of contaminant trends in a salt wedge estuary with sediment cores dated using a multiple proxy approach, Mar. Environ. Res., 64, 225-246, 2007.

Cearreta, A., Irabien, M.J., Leorri, E., Yusta, I., Quintailla, A., and Zabaleta, A.: Environmental transformation of the Bilbao estuary, N. Spain: microfaunal and geochemical proxies in the recent sedimentary record, Mar. Pollut. Bull., 44, 487-503, 252002.

Chang, S.K. and Lee, K.S.: A study on the recent foraminifera of the intertidal flats of Ansan Bay, Korea, J. Geol. Soc. Korea, 20, 171-188, 1984.

Choi, H.G., Moon, H.B., Choi, M., Yu, J., and Kim, S.S.: Mussel watch program for organic contaminants along the Korean coast, 2001-2007, Environ. Monit. Assess., 169, 473-485, 2010.

30 Dählback, B. and Gunnarsson, L.A.H.: Sedimentation and sulfate reduction under a mussel culture, Mar. Biol. 63, 269-275, 1981.

De Grave, S., Moor, S.J., and Burnell, G.: Changes in benthic macrofauna associated with intertidal oyster, Crassostrea gigas (Thunberg) culture, J. Shellfish Res., 17, 1137-1142, 1998. 
Biogeosciences Discuss., https://doi.org/10.5194/bg-2017-383

Manuscript under review for journal Biogeosciences

Discussion started: 1 November 2017

(c) Author(s) 2017. CC BY 4.0 License.

Diaz, R.J. and Rosenberg, R.: Spreading dead zones and consequences for marine ecosystems, Science, 321, 926-929, 2008.

Di Gregorio, D.E., Fernández Niello, J.O., Huck, H., Somacal, H., and Curutchet, G.: ${ }^{210} \mathrm{~Pb}$ dating of sediments in a heavily contaminated drainage channel to the La Plata estuary in Buenos Aires Argentina, Appl. Radiat. Isot., 65, 126-130, 2007.

Dolven, J.K., Alve, E., Rygg, B., and Magnusson, J.: Defining past ecological status and in situ reference conditions using 5 benthic foraminifera: A case study from the Oslofjord, Norway, Ecol Indic, 29, 219-233, 2013.

Doney, S.C.: The growing human footprint on coastal and open-ocean biogeochemistry, Science, 328, 1512-1516, 2010.

Duarte, P., Labarta, U., and Fernández-Reiriz, M.J.: Modelling local food depletion effects in mussel rafts of Galician Rias, Aquaculture, 274, 300-312, 2008.

Dubois, S., Marin-Léal, J.C., Ropert, M., and Lefebvre, S.: Effects of oyster farming on macrofaunal assemblage associated

10 with Lanice conchilega tubeworm populations: A trophic analysis using natural stable isotopes, Aquaculture, 271, 336-349, 2007.

Emerson, S., Cranston, R.E., and Liss, P.S.: Redox species in a reducing fjord: equilibrium and kinetic consideration, Deep Sea Res. Part A.-Oceanogr. Res. Pap., 26, 859-878, 1979.

Folk, R.L.: Petrology of the Sedimentary Rocks: Hemphill, Austin, Texas, 170 pp, 1968.

15 Forrest, B.M. and Creese, R.G.: Benthic impacts of intertidal oyster culture, with consideration of taxonomic sufficiency, Environ. Monit. Assess., 112, 159-176, 2006.

Forrest, B.M., Keeley, N.B., Hopkins, G.A., Webb, S.C., and Clement, D.M.: Bivalve aquaculture in estuaries: Review and synthesis of oyster cultivation effects, Aquaculture, 298, 1-15, 2009.

Foster, W.J., Chátelet, E.A., and Rogerson, M.: Testing benthic foraminiferal distributions as a contemporary quantitative approach to biomonitoring estuarine heavy metal pollution, Mar. Pollut. Bull., 64, 1039-1048, 2012.

Francescangeli, F., Armynot du Chatelet, E., Billon, G., Trentesaux, A. and Bouchet, V.M.P.: Palaeo-ecological quality status based on foraminifera of Boulognesur-Mer harbor (Pas-de-Calais, Northeastern France) over the last 200 years, Mar. Environ. Res., 117, 32-43, 2016.

Gilbert, D., Rabalais, N.N., Díaz, R.J., and Zhang, J.: Evidence for greater oxygen decline rates in the coastal ocean than in

25 the open ocean, Biogeosciences, 7, 2283-2296, 210.

Gooday, A.J., Jorissen, F., Levin, L.A., Middelburg, J.J., Naqvi, S.W.A., Rabalais, N.N., Scranton, M., and Zhang, J.: Historical records of coastal eutrophication-induced hypoxia, Biogeoscience, 6, 1707-1745, 2009.

Grenz, C.: Quantification et de la biodeposition en zones de production conchylicole intensive en Mediterranee, Ph.D. thesis, Universite d’Aix, Marseille II, France, 144 pp., 1989.

30 Grousset, F.E., Jouanneau, J.M., Castaing, P., Lavaux, G., and Latouche, C.: A 70 year record of contamination from industrial activity along the Garonne River and its tributaries (SW France), Estuar. Coast. Shelf Sci., 48, 401-414, 1999.

Hargrave, B.T.: A scientific review of the potential environmental effects of aquaculture in aquatic ecosystems, Can. Tech. Rep. Fish. Aquat. Sci. 2450, 1, 1-35, 2003. 
Biogeosciences Discuss., https://doi.org/10.5194/bg-2017-383

Manuscript under review for journal Biogeosciences

Discussion started: 1 November 2017

(c) Author(s) 2017. CC BY 4.0 License.

Hayward, B.W., Sabaa, A., and Grenfell, H.R.: Benthic foraminifera and the late Quaternary (last 150ka) paleoceanographic and sedimentary history of the Bounty Trough, east of Newzealand, Paleogeogr. Paleoclimatol. Paleoecol., 211, 59-93, 2004. Helly, J. and Levin, L.A.: Global distribution of naturally occurring marine hypoxia on continental margins, Deep-Sea Res. Part I-Oceanogr. Res. Pap., 51, 1159-1168, 2004

5 Ip, C.C.M., Li, X.-D., Zhang, G., Wai, O.W.H., and Li, Y.-S.: Trace metal distribution in sediments of the Pearl River Estuary and the surrounding coastal area, South China, Enviro. Pollut., 147, 311-323, 2007.

Irabien, M.J., Cearreta, A., Leorri, E., Gómez, J., and Viguri, J.: A 130 year record of pollution in the Suances estuary (southern Bay of Biscay): Implications for environmental management, Mar. Pollut. Bull., 56, 1719-1727, 2008.

Jaramillo, E, Bertrán, C., and Bravo, A.: Mussel biodeposition in an estuary in southern Chile, Mar. Ecol.-Prog. Ser., 82, 85-

$1094,1992$.

Jeong, K.S., Cho, J.H., Lee, J.H., and Kim, K.H.: Accumulation history of anthropogenic heavy metals (Cu, Zn, and Pb) in Masan Bay sediments, southeastern Korea: a role of chemical front in the water column. Geosci. J., 10, 445-455, 2006.

Kaiser, M.J., Laing, I., Utting, S.D., and Burnell, G.M.: Environmental impacts of bivalve mariculture, J. Shellfish Res., 17, 59-66, 1998.

15 Kalantzi, I., Shimmield, T.M., Pergantis, S.A., Papageorgiou, N., Black, K.D., and Karakassis, I.: Heavy metals, trace elements and sediment geochemistry at four Mediterranean fish farms. Sci. Total Environ. 444, 128-137, 2013.

Kersten, M. and Förstner, U.: Chemical fractionation of heavy metals in anoxic estuarine and coastal sediments, Water Sci. Technol., 18, 121-130, 1986.

Kim, B.K., Park, S.J., Lee, M.O., Lee, Y.G., and Kim, J.K.: Characteristics of sedimentary environments in Gamak Bay based on numerical experiments, J. Korea Soc. Mar. Environ. \& Energy, 17, 70-80, 2014.

Kim, D.M.: Estimation of nutrients transport in Kamak Bay using the ecohydrodynamic model, J. Environ. Sci., 12, 745-751, 2003.

Kim, J.-B., Lee, S.Y., Yu, J., Choi, Y.H., Jung, C.-S., and Lee, P.-Y.: The characteristics of Oxygen Deficient Water Mass in Gamak Bay, J. Korea Soc. Mar. Environ. Eng., 9, 216-224, 2006.

25 Kitano, Y., Sakata, M., and Matsumoto, E.: Partitioning of heavy metals into mineral and organic fractions in a sediment core from Tokyo Bay. Geochem. Cosmochim. Acta, 44, 1279-1285, 1980.

Korea Institute of Geoscience and Mineral Resources (KIGAM): Explanatory note of the Mokpo and Yeosu sheets, 1-45, 2002 Lee, G.H.: The pattern of the sea water circulation in Kamak Bay, Bull. Korean Fish, Tech. Soc., 28, 117-131, 1992.

Lee, G.H. and Cho, K.D.: Distributions of the temperature and salinity in kamak Bay, Bull. Korean Fish. Soc., 23, 25-39, 1990.

30 Lee, M.C. and Chang, S.D.: Seawater exchange in Gamak Bay, J. Korean Oceanol. Soc., 17, 12-18, 1982.

Lee, M.O., Kim, B.K., Kwon, Y.A., and Kim, J.K.: Characteristics of the marine environment and algal blooms in Gamak Bay, Fish. Sci., 75, 401-411, 2009. 
Biogeosciences Discuss., https://doi.org/10.5194/bg-2017-383

Manuscript under review for journal Biogeosciences

Discussion started: 1 November 2017

(c) Author(s) 2017. CC BY 4.0 License.

Lee, Y.G., Hwang, J.Y., and Jung, K.K.: Surface sediment characteristics and clay minerals in Kamak Bay, J. Korean Earth Sci. Soc., 16, 477-48, 1995.

Lee, Y.G., Jeong, D.U., Kang, S.R., Kim, Y.W., Kim, S., Jung, E.H., and Lee, J.S.: The formation of hypoxia sediment and benthic foraminiferal change in Gamak Bay, southern coast of Korea, Ocean and Polar Res., 34, 53-64, 2012.

5 Lee, Y.G., Jeong, D.U., Lee, J.S., Choi, Y.H., and Lee, M.K.: Effects of hypoxia caused by mussel farming on benthic foraminifera in semi-closed Gamak Bay, South Korea, Mar. Pollut. Bull., 109, 566-581, 2016

Lee, Y.S. and Moon, S.Y.: The water quality in the Soho coastal seawaters of Gamak Bay before and after a typhoon, J. Korean Soc. Oceanography, 11, 117-123, 2006.

Lim D-I, Jung, S.W., Choi, M.S., Kang, S.M., Jung, H.S., and Choi, J.Y.: Historical record of metal accumulation and lead

10 source in the southeastern coastal region of Korea, Mar. Pollut. Bull., 74, 441-445, 2013.

Lim D-I., Jung, H.S., Kim, K.Y., Shin, H.H., and Jung, S.W.: Sedimentary records of metal contamination and eutrophication in Jinhae-Masan Bay, Korea, Mar. Pollut. Bull., 64, 2542-2548, 2012.

Loeblich, A.R., Jr. and Tappan, H.: Foraminifera of the Sahul Shelf and Timor Sea, Cushman Found. Foraminifer. Res., Special Publication 31,661 pp., 1964.

15 Long, E.R., Macdonald, D.D., Smith, S.L., and Calder, F.D.: Incidence of adverse biological effects within ranges of chemical concentrations in marine and estuarine sediments, Environ. Manage., 19, 81-97, 1995.

Lubis A.A.: Constant rate of supply (CRS) model for determining the sediment accumulation rates in the coastal area using ${ }^{210} \mathrm{~Pb}$, J. Coast. Dev., 10, 9-18, 2006.

Matoba Y.: Distribution of recent shallow water foraminifera of Matsushima Bay, Miyagi Prefecture, northeast Japan, The Sci.

20 Rep. of Tohoku Univ, second ser. (Geol.) 42, Japan, 85 pp, 1970.

Matisson, J. and Lindén, O.: Benthic macrofauna succession under mussels, Mytilus edulis L. (Bivalvia), cultured on hanging long-lines, Sarsia, 68, 97-102, 1983.

Ministry of Oceans and Fisheries: Establishment of action plans for model coastal environmental management areasenvironmental status of the Kamak Bay, a marine conservation area, 275 pp, 2001.

25 Murray, J.W.: Ecology and paleoecology of benthic foraminifera, John Wiley and Sons Inc., New York, 397 pp, 1991.

Murray, J.W.: Ecology and Applications of Benthic Foraminifera, Cambridge University Press, Cambridge, New York, 426 pp, 2006.

Paulmier, A. and Ruiz-Pino, D.: Oxygen minimum zones (OMZs) in the modern ocean, Prog. Oceanogr., 77, 331-350, 2008.

Pereira, P.M.F., Black, K.D., McLusky, D.S., and Nickell, T.D.: Recovery of sediments after cessation of marine fish farm

30 production, Aquaculture, 235, 315-330, 2004.

Pielou E.C.: The measurement of diversity in different types of biological collection, J. Theor. Biol., 13, 131-144, 1966. 
Biogeosciences Discuss., https://doi.org/10.5194/bg-2017-383

Manuscript under review for journal Biogeosciences

Discussion started: 1 November 2017

(c) Author(s) 2017. CC BY 4.0 License.

Rabalais, N.N., Turner, R.E., Wiseman, W.J., and Boesch, D.F.: A brief summary of hypoxia on the northern Gulf of Mexico continental shelf: 1985-1988, in: Modern and Ancient Continental Shelf Anoxia, Tyson, R.V. and Pearson, T.H. (Eds.), Geological Society, London, Special Publications, U.K., 58, 35-46, 1991.

Ridgway, J. and Shimmield, G.: Estuaries as repositories of historical contamination and their impact on shelf seas, Estuar.

5 Coast. Sci., 55, 903-928, 2002.

Romano, E., Bergamin, L., Ausili, A., Magno, M.C., and Gabellini, M.: Evolution of the anthropogenic impact in the Augusta Harbor (Eastern Sicily, Italy) in the last decades: benthic foraminifera as indicator of environmental status, Environ. Sci. Pollut. Res., 23, 10514-10528, 2016.

Ruiz-Fernández, A.C., Hillaire-Marcel C., Páez-Osuna F., Ghaleb B., and Soto-Jiménez M.: Historical trends of metal 10 pollution recorded in the sediments of the Culiacan River Estuary, Northwestern Mex, Appl. Geochem., 18, 577-588, 2003. Sabbatini, A., Bonatto, S., Bianchelli, S., Pusceddu, A., Danovaro, R., and Negri, A.: Foraminiferal assemblages and trophic state in coastal sediments of the Adriatic Sea, J. Mar. Syst., 105, 163-174, 2012.

Sanchez-Cabeza, J.A. and Ruiz-Fernandez, A.C.: ${ }^{210} \mathrm{~Pb}$ sediment radiochronology: An integrated formulation and classification of dating models, Geochim. Cosmochim. Acta, 82, 183-200, 2012.

15 Scott, D.B., Tobin, R., Williamson, M., Medioli, F.S., Latimer, J.S., Boothman, W.A, Asioli, A., and Haury, V.: Pollution monitoring in two North American estuaries: historical reconstructions using benthic foraminifera, J. Foraminifer. Res., 35, 65-82, 2005.

Seo, J.Y., Park, S.H., Lee, H., and Choi, J.W.: Structural changes in macrozoobenthic communities due to summer hypoxia in Gamak bay, Korea, Ocean Sci. J., 47, 27-40, 2012.

20 Shannon C.E. and Weaver W.: The mathematical theory of communication, University Illinois Press, Urbana, USA, 77 pp, 1963.

Solomon, O.O. and Ahmed, O.O.: Ecological consequences of oysters culture: A review. Int. J. of Fish. Aquat. Stud., 4, 1-6, 2016.

Stevens, C., Plew, D., Hartstein, N., and Fredriksson, D.: The physics of open-water shellfish aquaculture, Aquac. Eng., 38, 25 145-160, 2008.

Strohmeier, T., Duinker, A., Strand, Ø., and Aure, J.: Temporal and spatial variation in food availability and meat ratio in a longline mussel farm (Mytilus edulis), Aquaculture, 276, 83-90, 2008.

Tsujimoto, A., Nomura, R., Yasuhara, M., and Yoshikawa, S.: Benthic foraminiferal assemblages in Osaka Bay, southwestern Japan: faunal changes over the last 50 years, Paleontol. Res., 10, 141-161, 2006a.

30 Tsujimoto, A., Nomura, R., Yasuhara, M., Yamazaki, H., and Yoshikawa, S.: Impact of eutrophication on shallow marine benthic foraminifers over the last 150 years in Osaka Bay, Japan, Mar. Micropaleontol., 60, 258-268, 2006b. 
Biogeosciences Discuss., https://doi.org/10.5194/bg-2017-383

Manuscript under review for journal Biogeosciences

Discussion started: 1 November 2017

(c) Author(s) 2017. CC BY 4.0 License.

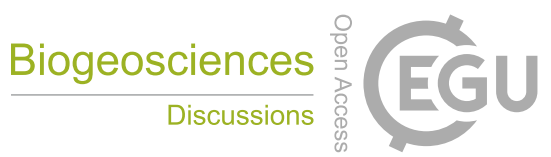

(c) (i)

Tsujimoto, A., Yasuhara, Nomura, R., Yamazaki, H. Sampei, Y., Hirose, K., and Yoshikawa, S.: Development of modern benthic ecosystems in eutrophic coastal oceans: the foraminiferal record over the last 200 years, Osaka Bay, Japan, Mar. Micropaleontol., 69, 225-239, 2008.

Wang, P., Hong, X., and Zha0, Q.: Living foraminifera and ostracoda: distribution in the coastal area of the East China Sea

5 and Huanghai Sea, in: Marine Micropaleontology of China, Wang, P. (Eds.), China Ocean Press, Beijing, 243-255, 1985.

Woo, H.J. and Lee, Y.G.: Foraminiferal characteristics in Ganghwa tidal flat, J. Korean Wetl. Soc., 8, 51-65, 2006.

Yasuhara, M., Hunt, G., Breitburg, D., Tsujimoto, A. and Katsuki, K.: Human-induced marine ecological degradation: micropaleontological perspectivites, Ecol. Evol., 2, 3242-3268, 2012.

Wu, R.S.S.: The environmental impact of marine fish culture: Towards a sustainable future, Mar. Pollut. Bull., 31, 159-166, 101995. 
Biogeosciences Discuss., https://doi.org/10.5194/bg-2017-383

Manuscript under review for journal Biogeosciences

Discussion started: 1 November 2017

(c) Author(s) 2017. CC BY 4.0 License.

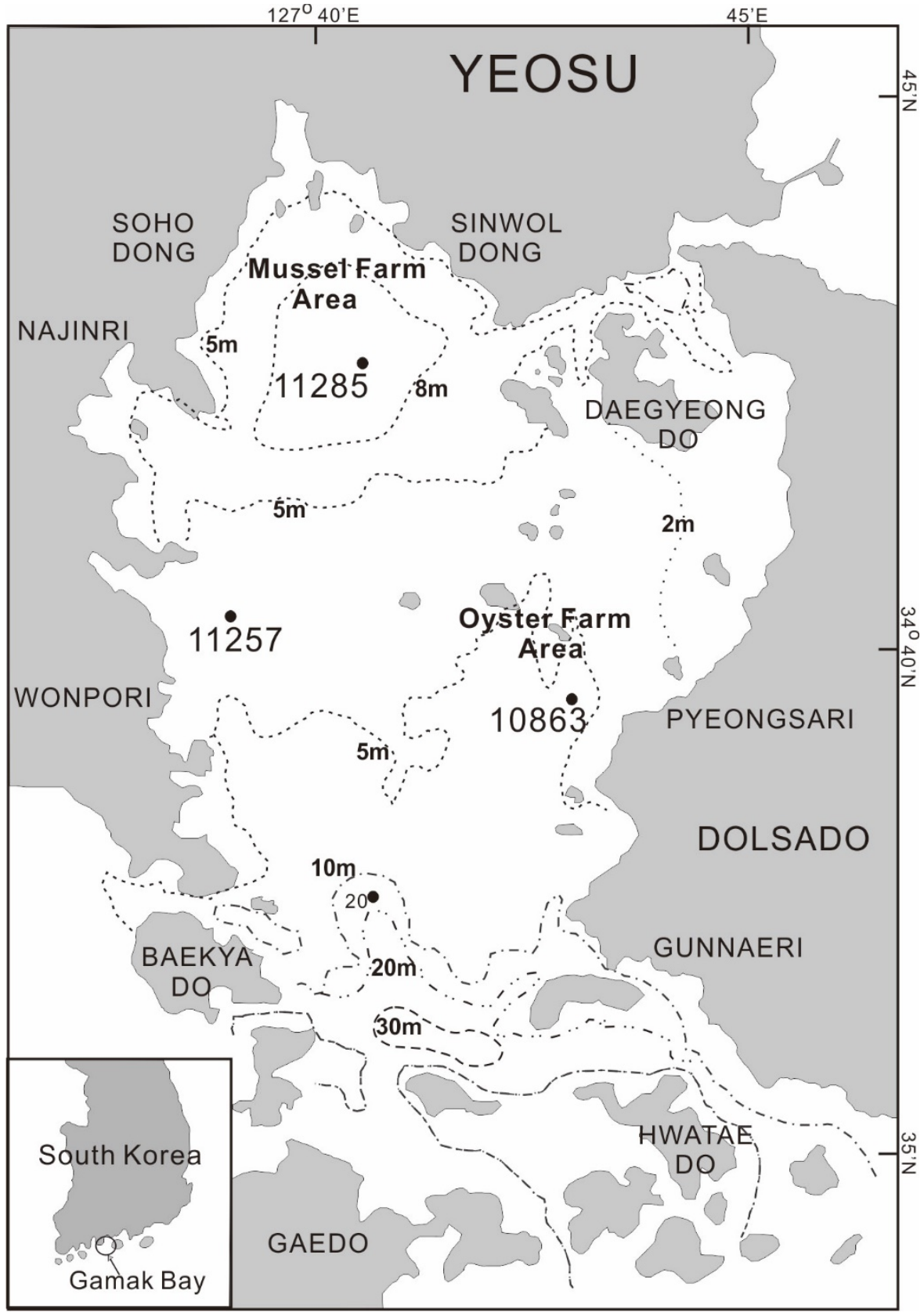

Figure 1: Sample locations of sediment cores 11257 (western area), 10863 (eastern area) and 11285 (northwestern area), and bathymetric map in semi-closed Gamak Bay, South Korea. 
Biogeosciences Discuss., https://doi.org/10.5194/bg-2017-383

Manuscript under review for journal Biogeosciences

Discussion started: 1 November 2017

(c) Author(s) 2017. CC BY 4.0 License.
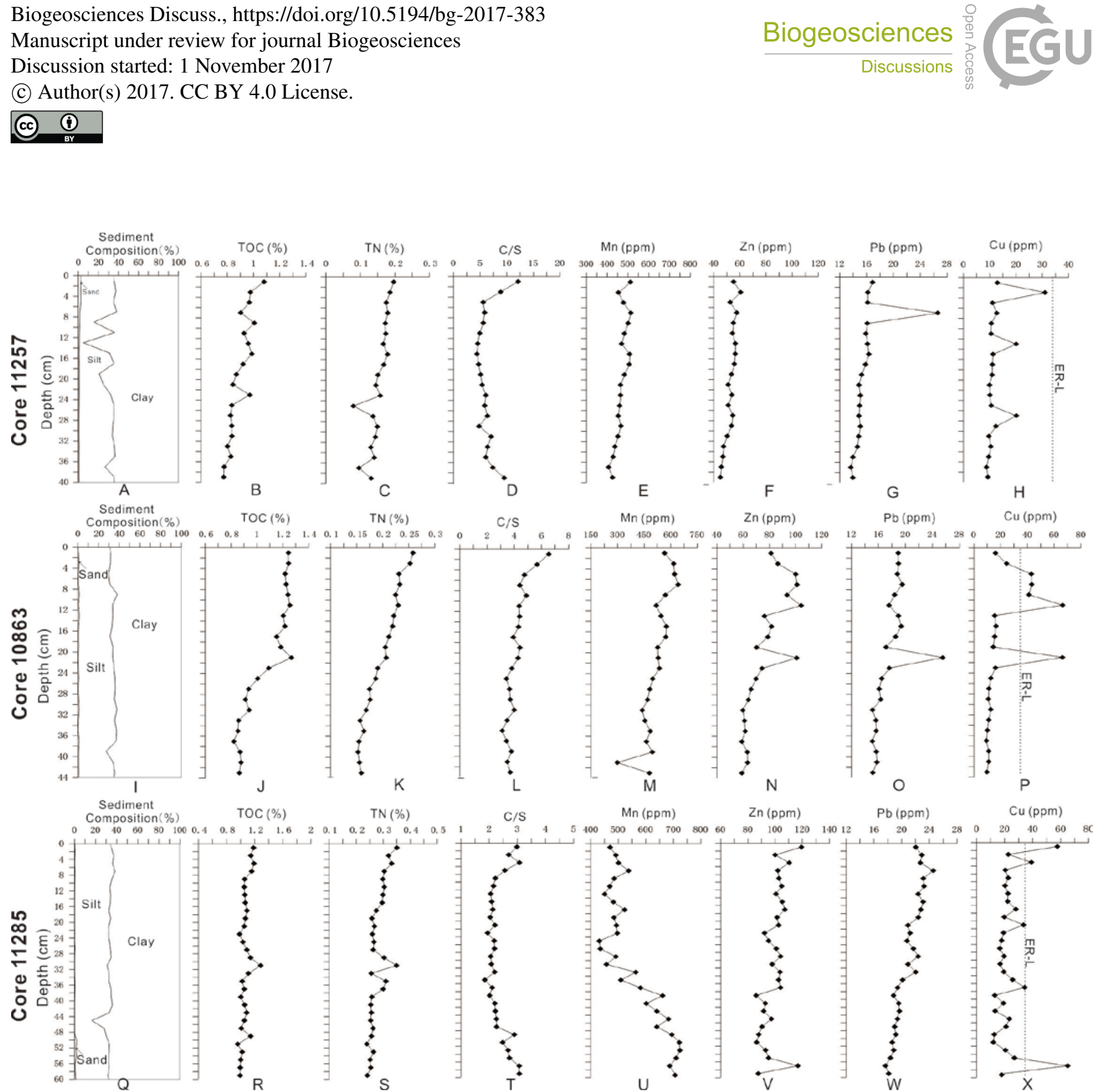

TOC $(\%)$

$\mathrm{TN}(\%)$
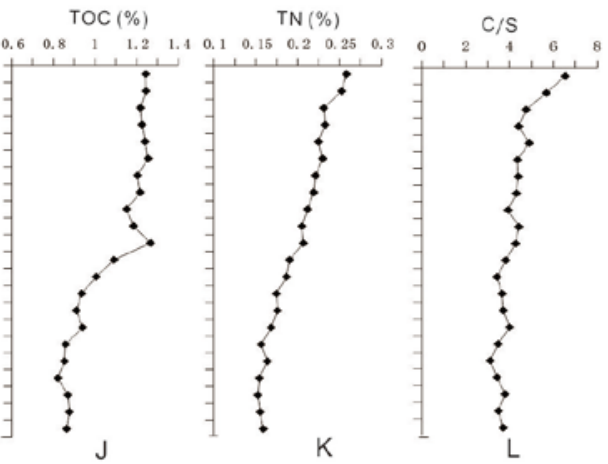

$\mathrm{Mn}(\mathrm{ppm})$

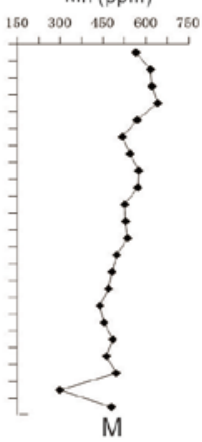

$\mathrm{Zn}(\mathrm{ppm})$

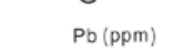

$\mathrm{Cu}(\mathrm{ppm})$

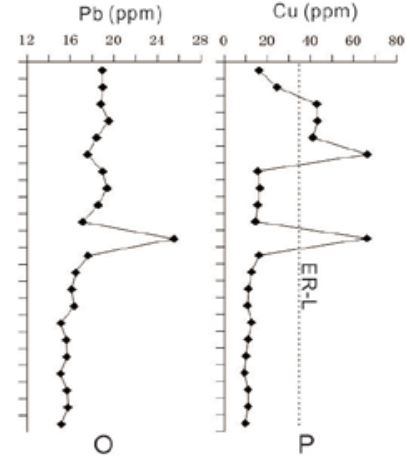

TOC (\%)

$\mathrm{TN}(\%)$

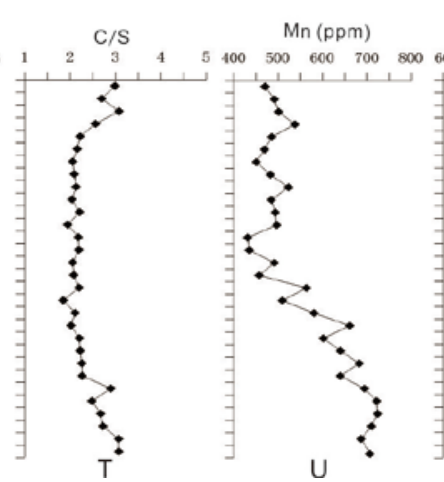

$\mathrm{Zn}(\mathrm{ppm})$

$\mathrm{Pb}(\mathrm{ppm})$
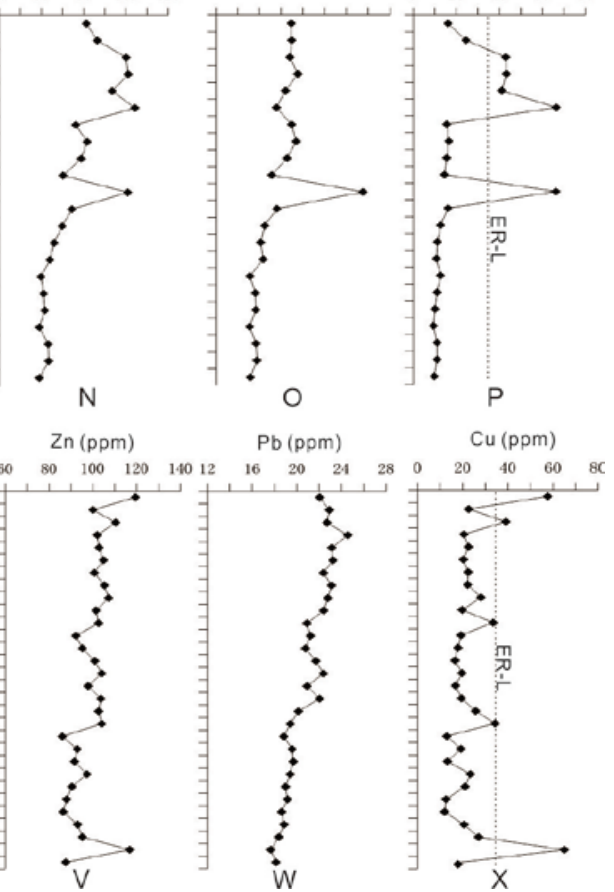

Figure 2: Variation of sediment composition (A, I, Q), total organic carbon (TOC) (B, J, R), total nitrogen (TN) (C, K, S), total organic carbon/total sulfur (C/S) (D, L, T), Mn (E, M, U), Zn (F, N, V), Pb (G, O, W) and Cu (H, P, X) of sediment cores 11257 (A-H), 10863 (I$\mathrm{P})$ and $11285(\mathrm{Q}-\mathrm{X})$ in three sediment cores $(11257,10863,11285)$. 
Biogeosciences Discuss., https://doi.org/10.5194/bg-2017-383

Manuscript under review for journal Biogeosciences

Discussion started: 1 November 2017

(c) Author(s) 2017. CC BY 4.0 License.
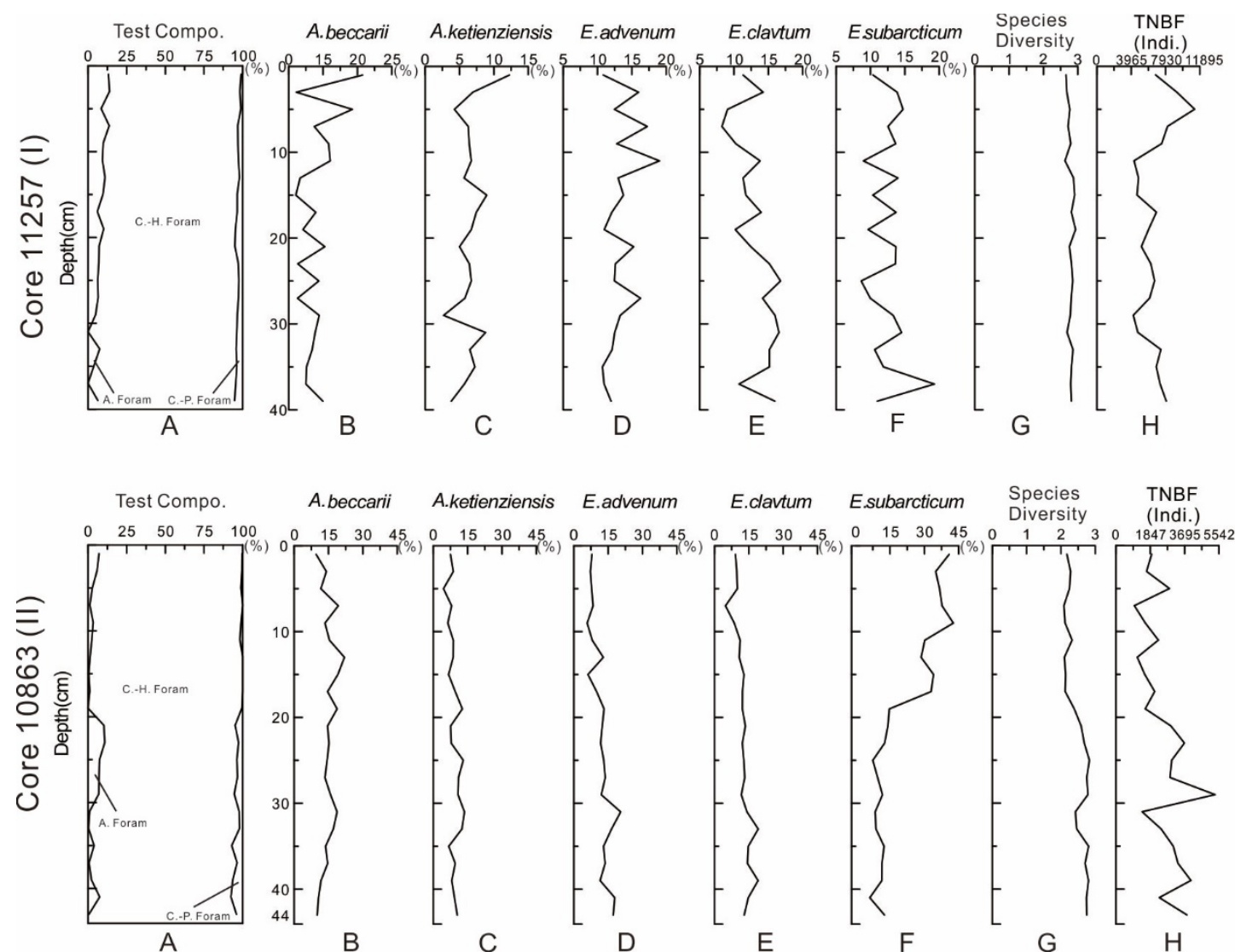

E.clavtum
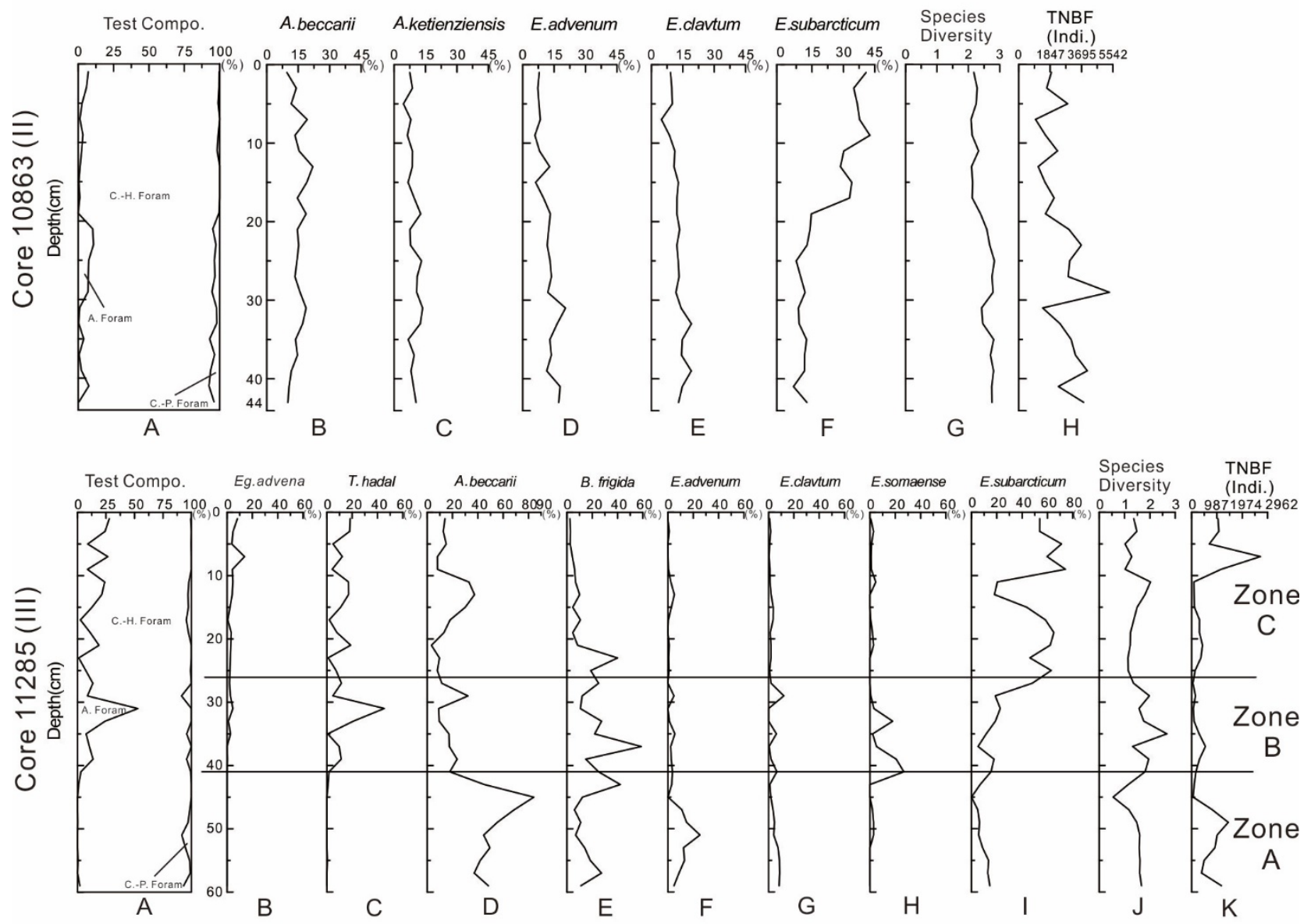

Figure 3: Variation of test composition (I-A, II-A, III-A), dominant species (Eggerella advena: II-B, Trochammina hadai: III-C, Ammonia beccarii: I-B, II-B, III-D, Ammonia ketienziensis: I-C, II-C, Buccella advena: III-E, Elphidium advenum: I-D, II-D, II-F, E. clavatum: I-E, II-E, III-G, E. subarcticum: I-F, II-F, III-I, E. somaense: III-H), species diversity (I-G, II-G, III-J) and total number of benthic foraminifera 5 (I-H, II-H, III-K) in benthic foraminiferal assemblages of three sediment cores $(11257,10863$, 11285). Note, Compo.: composition, C-H 
Biogeosciences Discuss., https://doi.org/10.5194/bg-2017-383

Manuscript under review for journal Biogeosciences

Discussion started: 1 November 2017

(c) Author(s) 2017. CC BY 4.0 License.

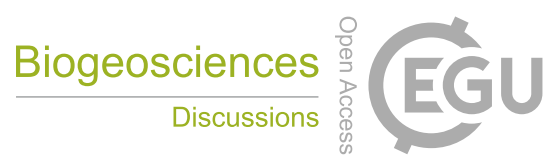

(c) (i)

Foram.: Calcareous-Hyaline Foraminifera, C-P Foram.: Calcareous-Porcelain Foraminifera, A Foram.: Agglutinated Foraminifera, A.: Ammonia, E.: Elphidium, Eg.: Eggerella, TNBF: total number of benthic foraminifera, Indi.,: individual.

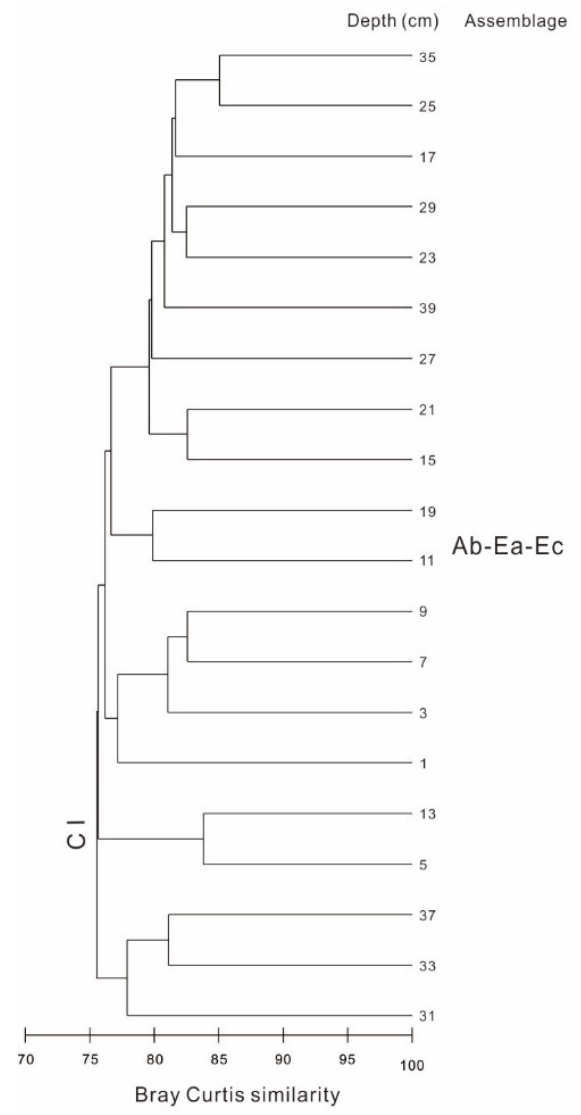

A: Core 11257

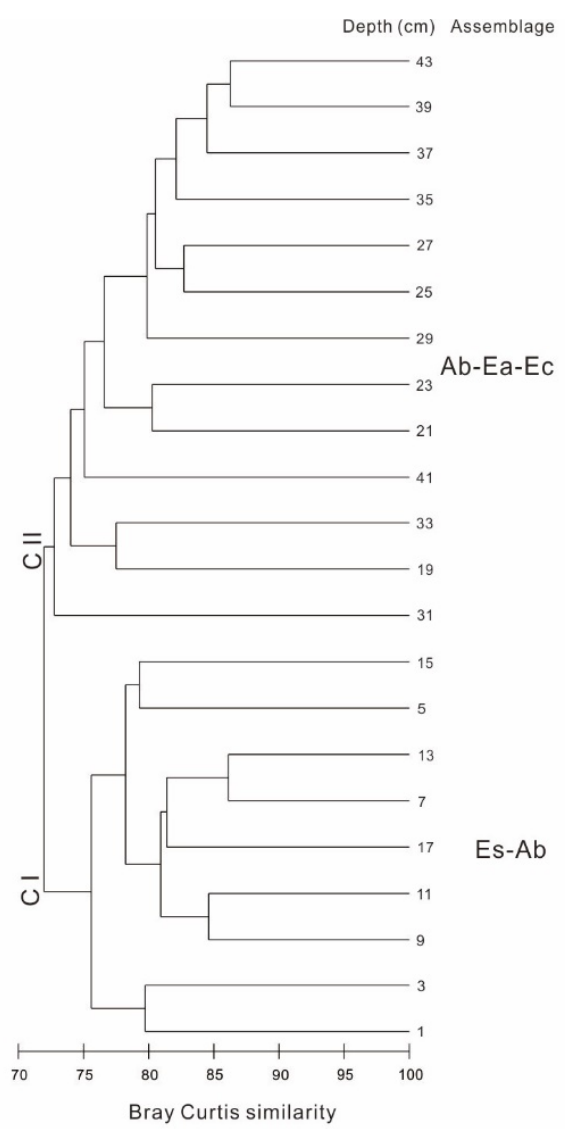

B: Core 10863

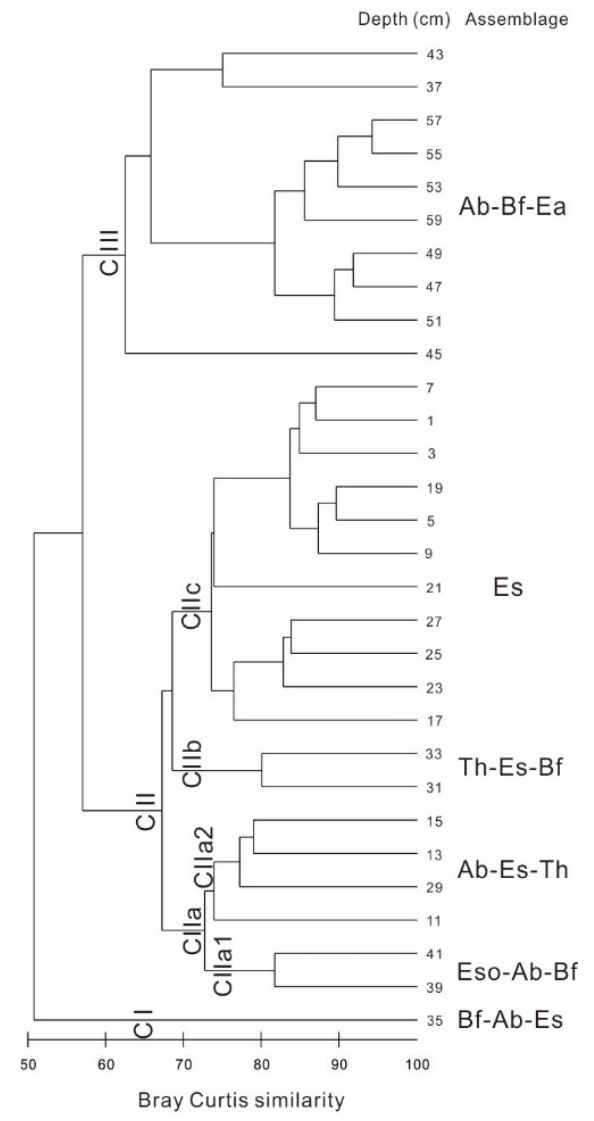

C: Core 11285

5 Figure 4: Cluster analysis using Bray-Curtis similarity of benthic foraminiferal assemblages in (A) sediment core 11257, (B) sediment core 10863 and (C) sediment core 11285 taken from Gamak Bay. Ab: Ammonia beccarii, Bf: Buccella frigida, Ea: Elphidium advenum, Ec: E. clavatum, Eso: E. somaense, Es: E. subarcticum, Th: Trochammina hadai. 
Biogeosciences Discuss., https://doi.org/10.5194/bg-2017-383

Manuscript under review for journal Biogeosciences

Discussion started: 1 November 2017

(c) Author(s) 2017. CC BY 4.0 License.

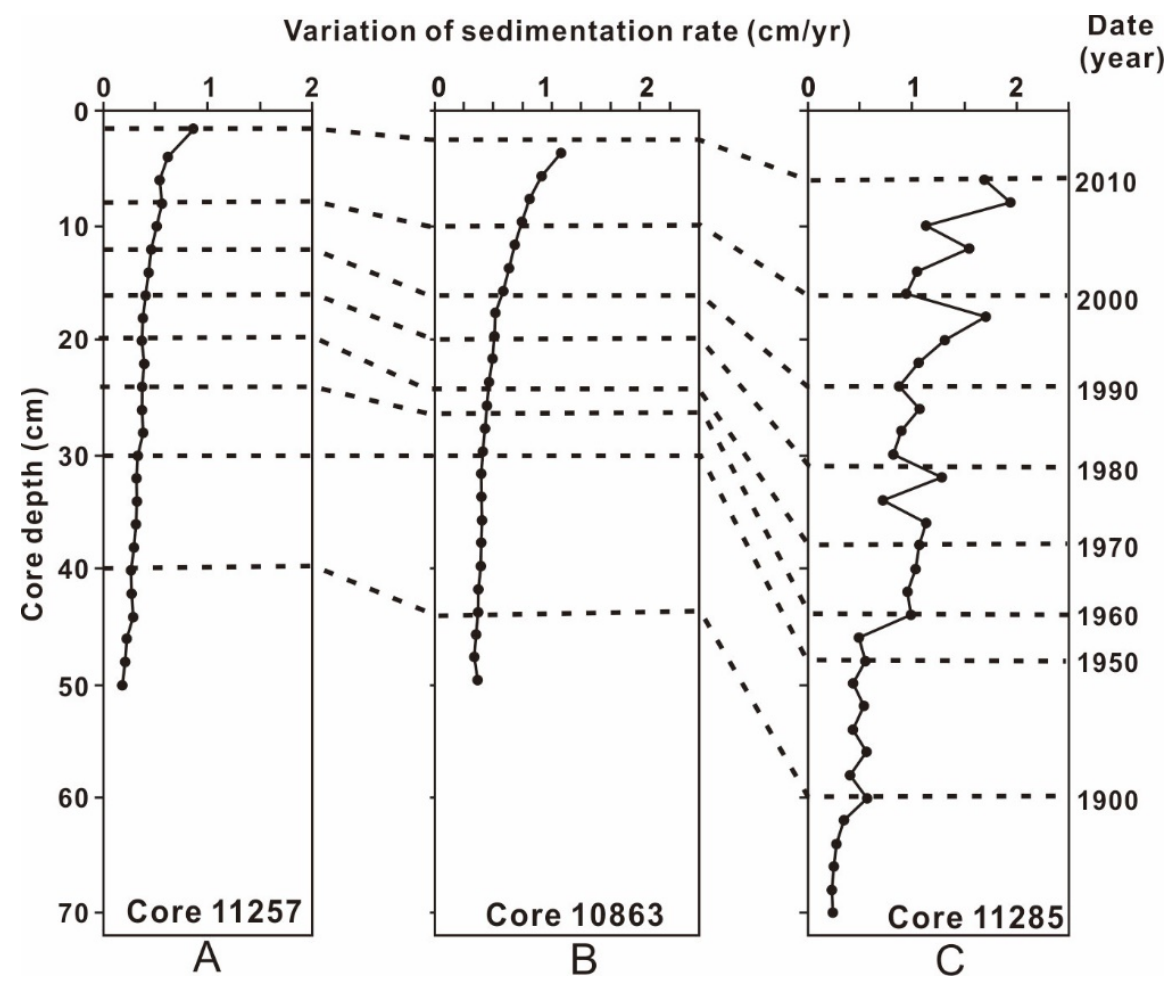

Figure 5: Variation of sediment age and sedimentation rate calculated from ${ }^{210} \mathrm{~Pb}$ dates of sediment cores 11257 (A), 10863 (B) and 11285 (C), using the constant rate of supply (CRS) model (Appleby and Oldfield, 1992). 
Biogeosciences Discuss., https://doi.org/10.5194/bg-2017-383

Manuscript under review for journal Biogeosciences

Discussion started: 1 November 2017

(c) Author(s) 2017. CC BY 4.0 License.

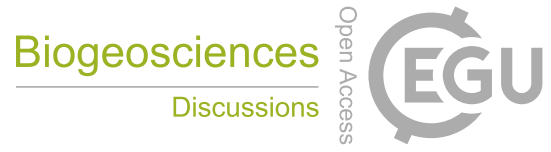

(c)

A

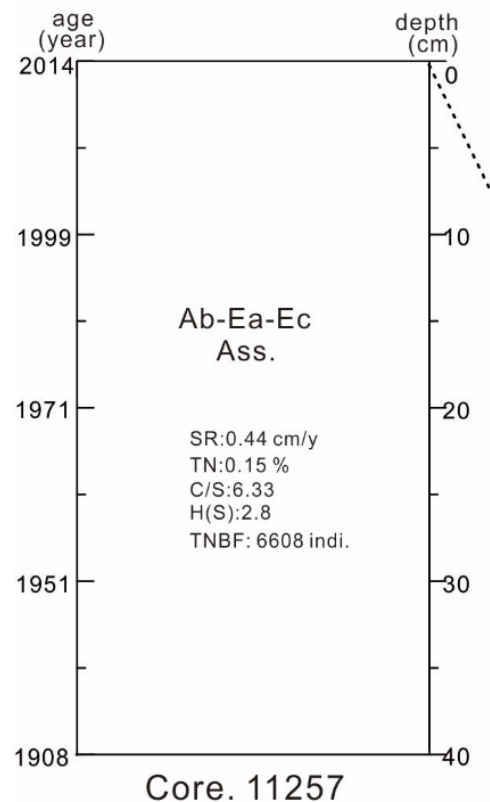

Core. 11257
B

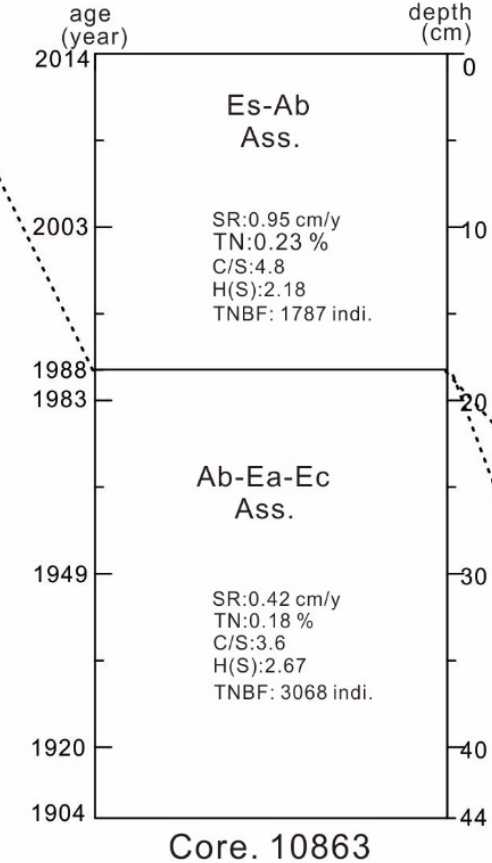

Core. 10863

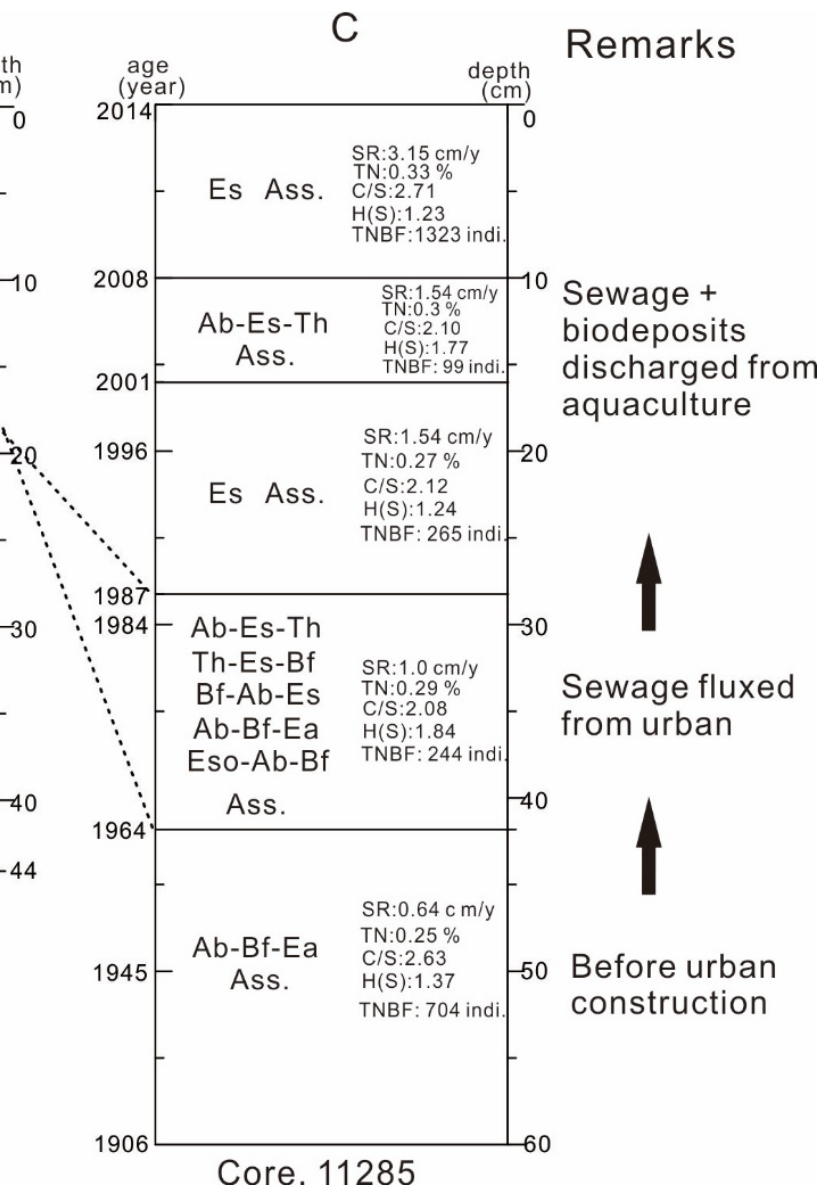

Figure 6: Correlation of benthic foraminiferal assemblages produced from (A) sediment core 11257, (B) sediment core 10863 and (C) sediment core 11285. Ab: Ammonia beccarii, Bf: Buccella frigida, Ea: Elphidium advenum, Ec: E. clavatum, Eso: E. somaense, Es: E. subarcticum, Th: Trochammina hadai. SR: sedimentation rate, TN: total nitrogen, C/S: total organic carbon/total sulfur, (H(S): species diversity, TNBF: total number of benthic foraminifera, Invi.: individual. 
Biogeosciences Discuss., https://doi.org/10.5194/bg-2017-383

Manuscript under review for journal Biogeosciences

Discussion started: 1 November 2017

(c) Author(s) 2017. CC BY 4.0 License.

(c) (1)
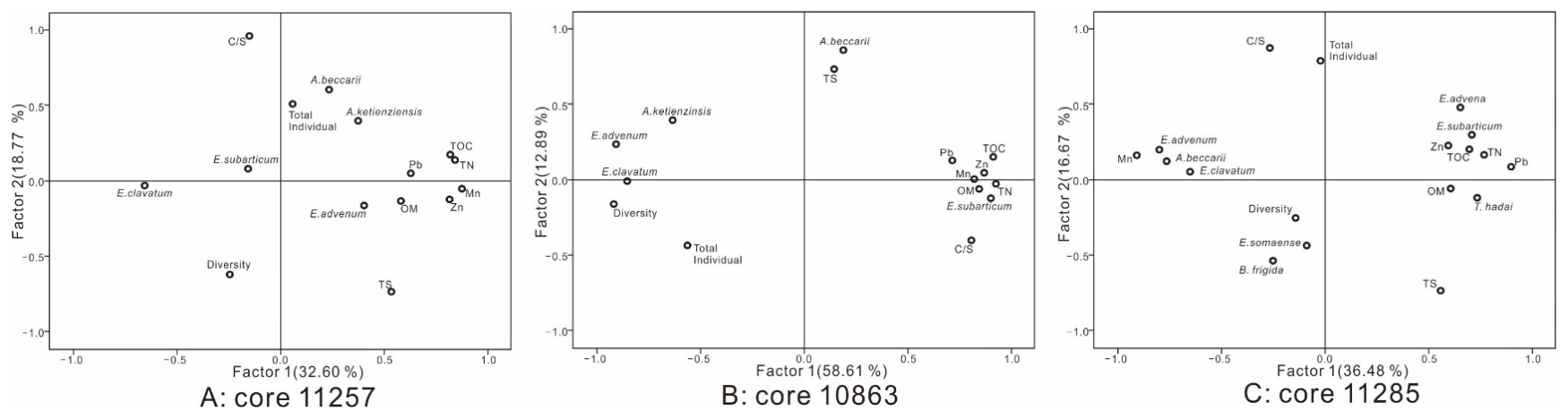

Figure 7: PCA (Principal Component Analysis) ordination diagram to statistic data of benthic foraminiferal assemblage and geochemistry in sediment cores 11257 (A), 10863 (B) and 11285 (C). OM: organic matter, TOC: total organic carbon, TN: total nitrogen, C/S: total organic carbon/total sulfur.

5

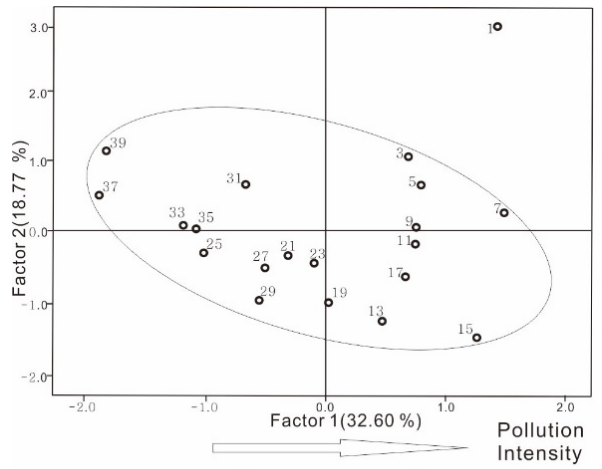

A: core 11257

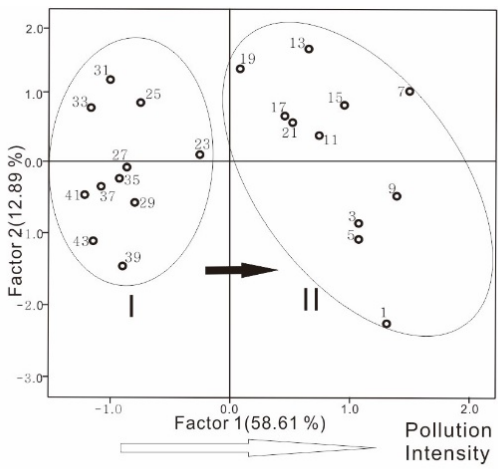

B: core 10863

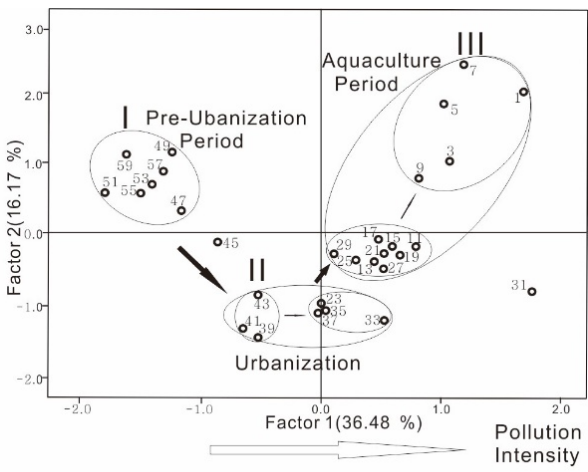

C: core 11285

Figure 8: Scatter diagram analysis to depth of sediment cores 11257 (A), 10863 (B) and 11285 (C), based on statistic data of benthic foraminiferal assemblage and geochemistry. 
Biogeosciences Discuss., https://doi.org/10.5194/bg-2017-383

Manuscript under review for journal Biogeosciences

Discussion started: 1 November 2017

(c) Author(s) 2017. CC BY 4.0 License.

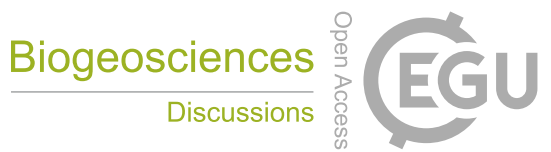

(c) (i)
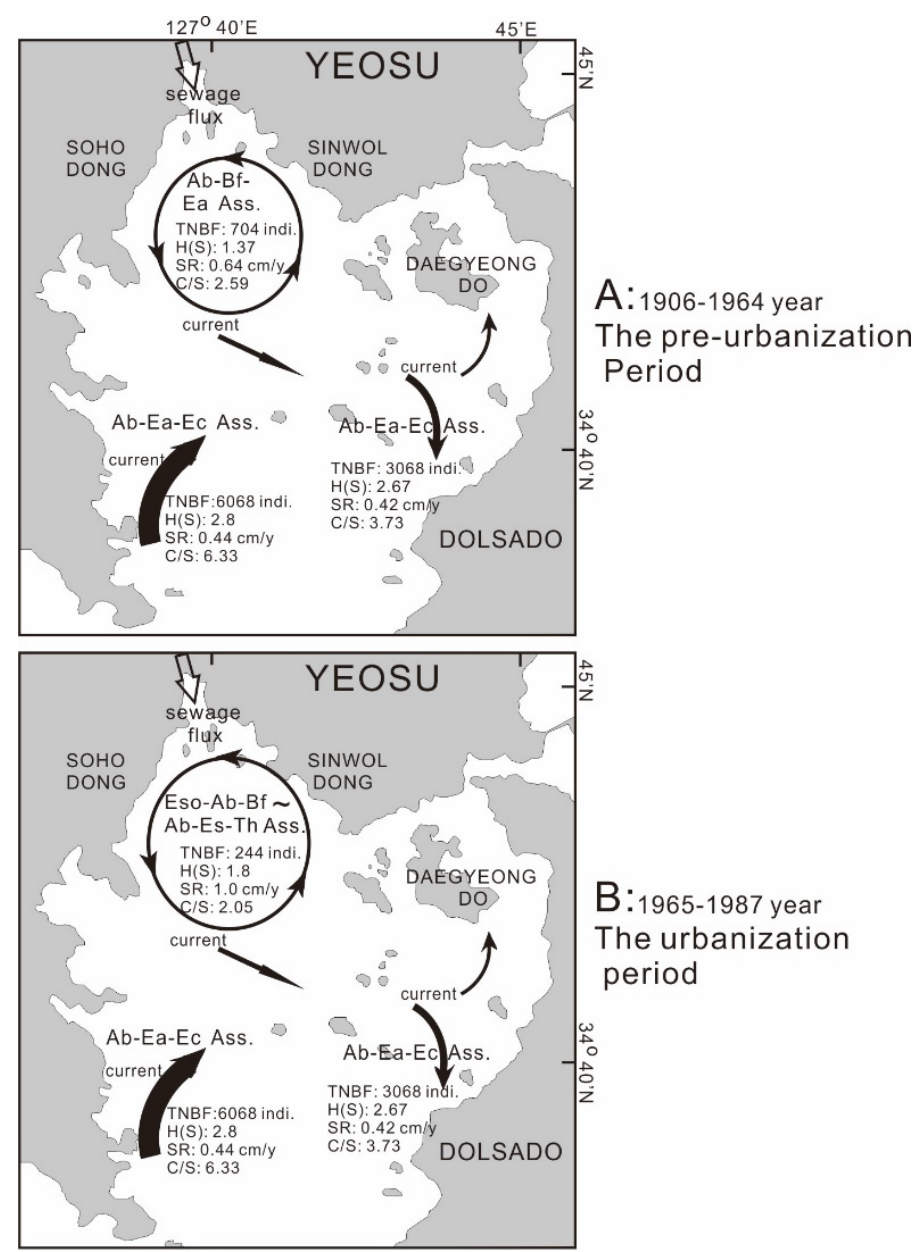

B:1965-1987 year

The urbanization

period

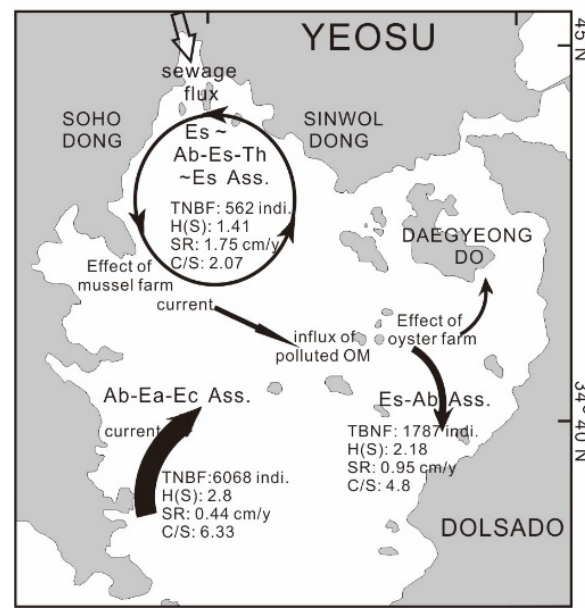

C:1988-2014 year

The aquaculture

Period

Figure 9: Synthesize mimetic diagram of the variation in historical records of the effects of anthropogenic pollution on benthic foraminifera over the last 110 years in Gamak Bay. Ab: Ammonia beccarii, Bf: Buccella frigida, Ea: Elphidium advenum, Ec: E. clavatum, Eso: E. somaense, Es: E. subarcticum, Th: Trochammina hadai. SR: sedimentation rate, OM: organic matter, C/S: total organic carbon/total sulfur, (H(S): species diversity, TNBF: total number of benthic foraminifera, Invi.: individual. 
Biogeosciences Discuss., https://doi.org/10.5194/bg-2017-383

Manuscript under review for journal Biogeosciences

Discussion started: 1 November 2017

(c) Author(s) 2017. CC BY 4.0 License.

(c) (i)

Table 1: Grain-size composition, trace metal and geochemical analysis of sediment core 11257, taken from western area of Gamak Bay. Note: Sedi: sediment, OM: organic matter, TOC: total organic carbon, TN: total nitrogen, TS: total sulfur, C/S: total organic carbon/total sulfur, C/N: total organic carbon/ total nitrogen.

\begin{tabular}{|c|c|c|c|c|c|c|c|c|c|c|c|c|c|c|c|c|c|c|c|c|c|c|c|c|c|}
\hline \multirow{2}{*}{$\begin{array}{l}\text { Depth } \\
(\mathrm{cm})\end{array}$} & \multicolumn{12}{|c|}{ Trace Metal Content $(\mathrm{mg} / \mathrm{kg})$} & \multicolumn{4}{|c|}{ Sedi. Composition (\%) } & \multirow{2}{*}{$\begin{array}{l}\text { Sedi. } \\
\text { Type }\end{array}$} & \multirow{2}{*}{$\begin{array}{l}\text { Mean } \\
(\varnothing)\end{array}$} & \multirow{2}{*}{$\mathrm{pH}$} & \multirow{2}{*}{$\begin{array}{l}\mathrm{OM} \\
(\%)\end{array}$} & \multirow{2}{*}{$\begin{array}{c}\text { TOC } \\
\text { (\%) }\end{array}$} & \multirow{2}{*}{$\begin{array}{l}\text { TN } \\
\text { (\%) }\end{array}$} & \multirow{2}{*}{$\begin{array}{l}\text { TS } \\
\text { (\%) }\end{array}$} & \multirow{2}{*}{$\begin{array}{r}\mathrm{C} / \mathrm{N} \\
\text { ratio }\end{array}$} & \multirow{2}{*}{$\begin{array}{l}\mathrm{C} / \mathrm{S} \\
\text { ratio }\end{array}$} \\
\hline & $\mathrm{Al}(\%)$ & $\mathrm{Fe}(\%)$ & $\mathrm{Mn}$ & $\mathrm{Zn}$ & $\mathrm{Cr}$ & $\mathrm{Ni}$ & $\mathrm{Cu}$ & Co & As & $\mathrm{Cd}$ & $\mathrm{Pb}$ & $\mathrm{Hg}$ & Gravel & Sand & Silt & Clay & & & & & & & & & \\
\hline 1 & 3.17 & 1.91 & 512.20 & 55.60 & 48.20 & 23.94 & 13.19 & 11.10 & 4.34 & 0.05 & 16.86 & 0.01 & 0.13 & 2.49 & 33.38 & 64.00 & (g)sM & 9.48 & 6.75 & 7.35 & 1.08 & 0.20 & 0.09 & 5.49 & 12.12 \\
\hline 3 & 3.11 & 1.88 & 457.80 & 60.60 & 47.40 & 23.17 & 31.15 & 10.80 & 4.50 & 0.06 & 16.28 & 0.02 & 0.07 & 2.34 & 35.16 & 62.43 & (g)sM & 9.33 & 6.75 & 7.77 & 0.98 & 0.19 & 0.11 & 5.25 & 8.86 \\
\hline 5 & 3.12 & 1.93 & 478.80 & 52.80 & 46.60 & 24.29 & 11.87 & 10.86 & 5.04 & 0.06 & 16.21 & 0.02 & 0.00 & 2.49 & 32.70 & 64.81 & M & 9.51 & 6.80 & 8.29 & 0.97 & 0.17 & 0.17 & 5.53 & 5.57 \\
\hline 7 & 3.54 & 2.00 & 513.60 & 57.60 & 52.60 & 24.21 & 13.06 & 10.89 & 4.81 & 0.07 & 26.65 & 0.01 & 0.00 & 1.62 & 36.66 & 61.72 & M & 9.36 & 6.83 & 6.58 & 0.90 & 0.18 & 0.15 & 5.03 & 5.84 \\
\hline 9 & 3.28 & 1.98 & 499.20 & 55.00 & 48.60 & 23.60 & 11.44 & 11.21 & 4.61 & 0.06 & 16.15 & 0.02 & 0.00 & 1.48 & 14.20 & 84.32 & M & 10.17 & 6.86 & 7.00 & 1.01 & 0.17 & 0.18 & 5.84 & 5.59 \\
\hline 11 & 3.01 & 1.93 & 482.80 & 54.20 & 45.80 & 23.89 & 11.28 & 11.27 & 4.52 & 0.06 & 15.88 & 0.02 & 0.00 & 1.13 & 35.01 & 63.86 & M & 9.48 & 6.87 & 7.15 & 0.93 & 0.17 & 0.19 & 5.34 & 4.93 \\
\hline 13 & 3.05 & 1.92 & 468.00 & 56.80 & 45.80 & 23.61 & 20.16 & 10.75 & 4.29 & 0.06 & 16.23 & 0.02 & 0.00 & 1.06 & 3.97 & 94.97 & M & 10.77 & 6.87 & 7.36 & 0.96 & 0.17 & 0.21 & 5.76 & 4.54 \\
\hline 15 & 3.40 & 2.01 & 507.00 & 56.60 & 50.40 & 24.75 & 12.71 & 11.37 & 4.12 & 0.13 & 16.41 & 0.02 & 0.00 & 0.76 & 30.58 & 68.66 & M & 9.82 & 6.88 & 8.14 & 0.99 & 0.18 & 0.22 & 5.52 & 4.41 \\
\hline 17 & 3.44 & 2.02 & 505.80 & 55.60 & 51.20 & 23.96 & 12.13 & 11.00 & 4.25 & 0.06 & 15.80 & 0.01 & 0.00 & 0.92 & 34.55 & 64.53 & M & 9.42 & 6.91 & 8.07 & 0.92 & 0.17 & 0.20 & 5.48 & 4.71 \\
\hline 19 & 3.36 & 2.00 & 483.00 & 53.60 & 50.00 & 23.66 & 12.08 & 10.74 & 4.32 & 0.06 & 15.29 & 0.01 & 0.00 & 0.93 & 19.99 & 79.08 & M & 9.79 & 6.91 & 7.23 & 0.87 & 0.15 & 0.17 & 5.75 & 5.09 \\
\hline 21 & 3.27 & 1.94 & 466.00 & 51.20 & 48.20 & 23.41 & 10.02 & 11.07 & 4.29 & 0.06 & 14.84 & 0.01 & 0.00 & 0.91 & 23.88 & 75.21 & M & 9.64 & 6.92 & 7.18 & 0.84 & 0.14 & 0.16 & 5.81 & 5.38 \\
\hline 23 & 3.39 & 1.99 & 466.60 & 53.40 & 50.20 & 24.16 & 10.36 & 11.21 & 4.40 & 0.06 & 15.10 & 0.02 & 0.00 & 0.85 & 31.40 & 67.75 & M & 9.52 & 6.96 & 7.07 & 0.97 & 0.16 & 0.16 & 6.16 & 6.07 \\
\hline 25 & 3.40 & 1.97 & 462.80 & 51.80 & 49.80 & 23.66 & 11.30 & 10.89 & 4.42 & 0.07 & 14.97 & 0.02 & 0.00 & 0.80 & 34.57 & 64.63 & M & 9.57 & 7.01 & 6.75 & 0.83 & 0.08 & 0.14 & 10.49 & 5.84 \\
\hline 27 & 3.24 & 1.90 & 453.00 & 54.60 & 47.80 & 23.42 & 20.05 & 10.92 & 4.35 & 0.06 & 14.70 & 0.01 & 0.00 & 0.64 & 35.08 & 64.28 & M & 9.50 & 7.06 & 7.31 & 0.82 & 0.14 & 0.13 & 6.03 & 6.37 \\
\hline 29 & 3.49 & 1.99 & 468.60 & 53.60 & 51.00 & 24.08 & 12.75 & 11.12 & 4.29 & 0.06 & 15.14 & 0.02 & 0.00 & 0.65 & 33.69 & 65.66 & M & 9.66 & 7.10 & 7.10 & 0.83 & 0.15 & 0.17 & 5.58 & 4.79 \\
\hline 31 & 3.45 & 1.91 & 451.40 & 50.40 & 51.20 & 23.30 & 9.92 & 10.46 & 4.26 & 0.08 & 14.68 & 0.01 & 0.00 & 0.65 & 33.25 & 66.10 & M & 9.66 & 7.12 & 7.41 & 0.84 & 0.14 & 0.12 & 5.82 & 7.08 \\
\hline 33 & 3.26 & 1.88 & 438.80 & 47.40 & 47.80 & 22.59 & 10.86 & 10.69 & 4.29 & 0.06 & 14.64 & 0.01 & 0.00 & 0.79 & 35.36 & 63.85 & M & 9.46 & 7.12 & 6.82 & 0.80 & 0.13 & 0.13 & 6.14 & 6.39 \\
\hline 35 & 2.99 & 1.83 & 426.20 & 46.80 & 45.40 & 22.47 & 9.68 & 10.38 & 4.12 & 0.06 & 13.97 & 0.01 & 0.00 & 0.72 & 35.86 & 63.42 & M & 9.46 & 7.15 & 7.27 & 0.83 & 0.14 & 0.14 & 5.90 & 6.06 \\
\hline 37 & 3.13 & 1.83 & 412.40 & 46.00 & 47.00 & 22.23 & 9.06 & 10.28 & 4.13 & 0.06 & 13.66 & 0.01 & 0.00 & 0.69 & 26.02 & 73.29 & M & 9.50 & 7.21 & 6.53 & 0.78 & 0.10 & 0.11 & 8.10 & 7.38 \\
\hline 39 & 2.90 & 1.79 & 424.60 & 45.00 & 44.40 & 21.60 & 9.43 & 10.23 & 3.96 & 0.05 & 13.94 & 0.01 & 0.00 & 0.66 & 35.07 & 64.26 & $\mathrm{M}$ & 9.47 & 7.24 & 6.53 & 0.77 & 0.13 & 0.08 & 5.88 & 9.52 \\
\hline Min. & 2.90 & 1.79 & 412.40 & 45.00 & 44.40 & 21.60 & 9.06 & 10.23 & 3.96 & 0.05 & 13.66 & 0.01 & 0.00 & 0.64 & 3.97 & 61.72 & & 9.33 & 6.75 & 6.53 & 0.77 & 0.08 & 0.08 & 5.03 & 4.41 \\
\hline Max. & 3.54 & 2.02 & 513.60 & 60.60 & 52.60 & 24.75 & 31.15 & 11.37 & 5.04 & 0.13 & 26.65 & 0.02 & 0.13 & 2.49 & 36.66 & 94.97 & & 10.77 & 7.24 & 8.29 & 1.08 & 0.20 & 0.22 & 10.49 & 12.12 \\
\hline Avg. & 3.25 & 1.93 & 468.93 & 52.93 & 48.47 & 23.50 & 13.12 & 10.86 & 4.37 & 0.07 & 15.87 & 0.01 & 0.01 & 1.13 & 30.02 & 68.84 & & 9.63 & 6.97 & 7.25 & 0.90 & 0.15 & 0.15 & 6.05 & 6.33 \\
\hline ER-L & N/A & N/A & N/A & 150.00 & 81.00 & 20.90 & 34.00 & N/A & 8.20 & 1.20 & 46.70 & 0.15 & & & & & & & & & & & & & \\
\hline ER-M & N/A & N/A & N/A & 410.00 & 370.00 & 51.60 & 270.00 & N/A & 70.00 & 9.60 & 218.00 & 0.71 & & & & & & & & & & & & & \\
\hline
\end{tabular}


Biogeosciences Discuss., https://doi.org/10.5194/bg-2017-383

Manuscript under review for journal Biogeosciences

Discussion started: 1 November 2017

(c) Author(s) 2017. CC BY 4.0 License.

(c) (1)

Table 2: Grain-size composition, trace metal and geochemical analysis of sediment core 10863, taken from eastern area of Gamak Bay. Note: Sedi: sediment, OM: organic matter, TOC: total organic carbon, TN: total nitrogen, TS: total sulfur, C/S: total organic carbon/total sulfur, C/N: total organic carbon/ total nitrogen.

\begin{tabular}{|c|c|c|c|c|c|c|c|c|c|c|c|c|c|c|c|c|c|c|c|c|c|c|c|c|}
\hline \multirow{2}{*}{$\begin{array}{r}\text { Depth } \\
(\mathrm{cm})\end{array}$} & \multicolumn{12}{|c|}{ Trace Metal Content (mg/kg) } & \multicolumn{3}{|c|}{ Sedi. Composition (\%) } & \multirow{2}{*}{$\begin{array}{l}\text { Sedi. } \\
\text { Type }\end{array}$} & \multirow{2}{*}{$\begin{array}{l}\text { Mean } \\
(\varnothing)\end{array}$} & \multirow{2}{*}{$\mathrm{pH}$} & \multirow{2}{*}{$\begin{array}{l}\mathrm{OM} \\
(\%)\end{array}$} & \multirow{2}{*}{$\begin{array}{l}\text { TOC } \\
\text { (\%) }\end{array}$} & \multirow{2}{*}{$\begin{array}{l}\mathrm{TN} \\
(\%)\end{array}$} & \multirow{2}{*}{$\begin{array}{c}\text { TS } \\
\text { (\%) }\end{array}$} & \multirow{2}{*}{$\begin{array}{l}\mathrm{C} / \mathrm{N} \\
\text { ratio }\end{array}$} & \multirow{2}{*}{$\begin{array}{l}\mathrm{C} / \mathrm{S} \\
\text { ratio }\end{array}$} \\
\hline & $\mathrm{Al}(\%)$ & Fe (\%) & $\mathrm{Mn}$ & $\mathrm{Zn}$ & $\mathrm{Cr}$ & $\mathrm{Ni}$ & $\mathrm{Cu}$ & Co & As & $\mathrm{Cd}$ & $\mathrm{Pb}$ & $\mathrm{Hg}$ & Sand & Silt & Clay & & & & & & & & & \\
\hline 1 & 3.59 & 2.37 & 565.00 & 81.20 & 47.60 & 23.46 & 16.18 & 10.38 & 4.11 & 0.08 & 18.93 & 0.02 & 0.54 & 31.02 & 68.44 & M & 9.68 & 6.74 & 8.30 & 1.24 & 0.26 & 0.19 & 4.82 & 6.54 \\
\hline 3 & 3.58 & 2.35 & 616.20 & 86.40 & 49.40 & 24.76 & 24.43 & 10.54 & 4.48 & 0.09 & 18.97 & 0.02 & 0.89 & 30.55 & 68.56 & M & 9.64 & 6.75 & 7.68 & 1.25 & 0.25 & 0.22 & 4.93 & 5.68 \\
\hline 5 & 3.57 & 2.39 & 621.40 & 100.00 & 48.80 & 24.58 & 42.93 & 10.51 & 4.65 & 0.09 & 18.81 & 0.02 & 0.50 & 29.33 & 70.17 & M & 9.75 & 6.75 & 7.92 & 1.22 & 0.23 & 0.26 & 5.27 & 4.74 \\
\hline 7 & 3.76 & 2.48 & 641.20 & 101.00 & 50.20 & 26.54 & 43.23 & 10.88 & 4.67 & 0.09 & 19.53 & 0.02 & 0.38 & 30.31 & 69.31 & M & 9.80 & 6.76 & 8.48 & 1.23 & 0.23 & 0.28 & 5.27 & 4.40 \\
\hline 9 & 3.51 & 2.32 & 569.80 & 93.40 & 47.40 & 23.97 & 41.07 & 10.34 & 4.23 & 0.09 & 18.39 & 0.02 & 1.32 & 36.68 & 62.00 & M & 9.38 & 6.80 & 8.69 & 1.24 & 0.22 & 0.25 & 5.52 & 4.89 \\
\hline 11 & 3.41 & 2.21 & 518.20 & 104.20 & 44.20 & 22.66 & 66.34 & 9.67 & 4.26 & 0.24 & 17.56 & 0.02 & 0.49 & 32.90 & 66.61 & M & 9.60 & 6.81 & 8.17 & 1.26 & 0.23 & 0.29 & 5.46 & 4.36 \\
\hline 13 & 3.55 & 2.30 & 545.00 & 76.20 & 45.60 & 23.40 & 15.57 & 10.25 & 4.47 & 0.08 & 18.96 & 0.02 & 1.33 & 32.26 & 66.41 & M & 9.54 & 6.83 & 8.28 & 1.20 & 0.22 & 0.27 & 5.44 & 4.39 \\
\hline 15 & 3.73 & 2.41 & 575.00 & 81.60 & 50.40 & 24.66 & 16.55 & 10.74 & 4.73 & 0.09 & 19.38 & 0.02 & 0.64 & 32.39 & 66.98 & M & 9.59 & 6.83 & 8.00 & 1.22 & 0.22 & 0.28 & 5.56 & 4.31 \\
\hline 17 & 3.47 & 2.37 & 572.00 & 78.80 & 47.40 & 23.73 & 15.57 & 10.50 & 4.40 & 0.09 & 18.55 & 0.02 & 0.43 & 30.63 & 68.94 & M & 9.78 & 6.86 & 7.77 & 1.15 & 0.21 & 0.29 & 5.45 & 3.93 \\
\hline 19 & 3.72 & 2.22 & 526.00 & 70.20 & 46.40 & 22.29 & 14.46 & 9.73 & 4.23 & 0.09 & 17.14 & 0.02 & 0.61 & 33.09 & 66.29 & M & 9.56 & 6.88 & 7.84 & 1.19 & 0.21 & 0.27 & 5.78 & 4.41 \\
\hline 21 & 3.72 & 2.22 & 528.80 & 100.80 & 52.20 & 24.66 & 66.19 & 9.62 & 4.00 & 0.09 & 25.53 & 0.02 & 0.27 & 33.21 & 66.52 & M & 9.53 & 6.92 & 7.89 & 1.27 & 0.21 & 0.30 & 6.13 & 4.28 \\
\hline 23 & 3.65 & 2.32 & 535.80 & 74.40 & 48.60 & 24.40 & 16.18 & 10.31 & 4.18 & 0.09 & 17.60 & 0.02 & 0.40 & 34.44 & 65.17 & M & 9.47 & 6.95 & 7.41 & 1.09 & 0.19 & 0.29 & 5.73 & 3.82 \\
\hline 25 & 3.37 & 2.22 & 497.60 & 69.80 & 45.40 & 22.56 & 12.67 & 9.94 & 4.14 & 0.08 & 16.49 & 0.02 & 0.70 & 35.10 & 64.20 & M & 9.48 & 6.98 & 7.05 & 1.01 & 0.19 & 0.29 & 5.39 & 3.43 \\
\hline 27 & 3.37 & 2.24 & 481.40 & 66.00 & 44.80 & 22.74 & 11.22 & 9.92 & 4.37 & 0.07 & 16.12 & 0.02 & 0.23 & 35.83 & 63.94 & M & 9.41 & 7.02 & 6.94 & 0.94 & 0.17 & 0.26 & 5.36 & 3.65 \\
\hline 29 & 3.56 & 2.22 & 469.00 & 64.00 & 46.00 & 22.61 & 10.81 & 10.10 & 4.78 & 0.07 & 16.36 & 0.02 & 0.71 & 34.66 & 64.63 & M & 9.58 & 7.05 & 7.54 & 0.91 & 0.18 & 0.25 & 5.18 & 3.70 \\
\hline 31 & 3.20 & 2.11 & 439.00 & 59.80 & 42.40 & 21.76 & 12.60 & 9.55 & 4.63 & 0.07 & 15.13 & 0.02 & 1.16 & 36.48 & 62.36 & $\mathrm{M}$ & 9.35 & 7.07 & 6.86 & 0.94 & 0.17 & 0.24 & 5.59 & 3.99 \\
\hline 33 & 3.20 & 2.18 & 453.80 & 61.00 & 42.40 & 22.67 & 11.07 & 9.93 & 4.74 & 0.07 & 15.63 & 0.02 & 0.38 & 35.05 & 64.57 & M & 9.50 & 7.08 & 6.74 & 0.86 & 0.16 & 0.25 & 5.49 & 3.48 \\
\hline 35 & 3.59 & 2.26 & 484.60 & 61.60 & 46.40 & 23.78 & 10.12 & 10.39 & 4.79 & 0.07 & 15.67 & 0.02 & 0.21 & 37.07 & 62.72 & M & 9.40 & 7.08 & 6.97 & 0.85 & 0.16 & 0.27 & 5.21 & 3.12 \\
\hline 37 & 3.13 & 2.15 & 462.60 & 59.00 & 41.20 & 21.97 & 9.38 & 9.61 & 4.12 & 0.06 & 15.11 & 0.01 & 1.10 & 35.82 & 63.08 & M & 9.44 & 7.10 & 7.00 & 0.82 & 0.15 & 0.24 & 5.32 & 3.43 \\
\hline 39 & 3.45 & 2.22 & 495.80 & 63.20 & 46.60 & 23.48 & 11.08 & 10.17 & 4.21 & 0.07 & 15.69 & 0.02 & 0.61 & 26.60 & 72.79 & M & 9.61 & 7.10 & 8.09 & 0.87 & 0.15 & 0.23 & 5.71 & 3.79 \\
\hline 41 & 3.27 & 2.22 & 298.60 & 63.40 & 44.40 & 23.55 & 11.07 & 10.16 & 4.27 & 0.07 & 15.78 & 0.02 & 0.58 & 33.21 & 66.22 & M & 9.39 & 7.13 & 7.22 & 0.88 & 0.16 & 0.25 & 5.65 & 3.49 \\
\hline 43 & 2.87 & 2.13 & 479.40 & 59.00 & 39.80 & 21.81 & 9.77 & 9.68 & 3.92 & 0.06 & 15.16 & 0.02 & 0.70 & 34.96 & 64.33 & $\mathrm{M}$ & 9.47 & 7.13 & 6.79 & 0.86 & 0.16 & 0.23 & 5.44 & 3.70 \\
\hline Min. & 2.87 & 2.11 & 298.60 & 59.00 & 39.80 & 21.76 & 9.38 & 9.55 & 3.92 & 0.06 & 15.11 & 0.01 & 0.21 & 26.60 & 62.00 & & 9.35 & 6.74 & 6.74 & 0.82 & 0.15 & 0.19 & 4.82 & 3.12 \\
\hline Max. & 3.76 & 2.48 & 641.20 & 104.20 & 52.20 & 26.54 & 66.34 & 10.88 & 4.79 & 0.24 & 25.53 & 0.02 & 1.33 & 37.07 & 72.79 & & 9.80 & 7.13 & 8.69 & 1.27 & 0.26 & 0.30 & 6.13 & 6.54 \\
\hline Avg. & 3.47 & 2.27 & 517.10 & 76.14 & 46.25 & 23.46 & 22.21 & 10.13 & 4.38 & 0.09 & 17.57 & 0.02 & 0.64 & 33.25 & 66.10 & & 9.54 & 6.94 & 7.62 & 1.07 & 0.20 & 0.26 & 5.44 & 4.16 \\
\hline ER-L & N/A & N/A & N/A & 150.00 & 81.00 & 20.90 & 34.00 & $\mathrm{~N} / \mathrm{A}$ & 8.20 & 1.20 & 46.70 & 0.15 & & & & & & & & & & & & \\
\hline ER-M & N/A & N/A & N/A & 410.00 & 370.00 & 51.60 & 270.00 & N/A & 70.00 & 9.60 & 218.00 & 0.71 & & & & & & & & & & & & \\
\hline
\end{tabular}


Biogeosciences Discuss., https://doi.org/10.5194/bg-2017-383

Manuscript under review for journal Biogeosciences

Discussion started: 1 November 2017

(c) Author(s) 2017. CC BY 4.0 License.

Table 3: Grain-size composition, trace metal and geochemical analysis of sediment core 11285, taken from northwestern area of Gamak Bay. Note: Sedi: sediment, OM: organic matter, TOC: total organic carbon, TN: total nitrogen, TS: total sulfur, C/S: total organic carbon/total sulfur, C/N: total organic carbon/ total nitrogen.

\begin{tabular}{|c|c|c|c|c|c|c|c|c|c|c|c|c|c|c|c|c|c|c|c|c|c|c|c|c|}
\hline \multirow{2}{*}{$\begin{array}{r}\text { Depth } \\
(\mathrm{cm})\end{array}$} & \multicolumn{12}{|c|}{ Trace Metal Content (mg/kg) } & \multicolumn{3}{|c|}{ Sedi. Composition (\%) } & \multirow{2}{*}{$\begin{array}{l}\text { Sedi. } \\
\text { Type }\end{array}$} & \multirow{2}{*}{$\begin{array}{l}\text { Mean } \\
(\emptyset)\end{array}$} & \multirow{2}{*}{$\mathrm{pH}$} & \multirow{2}{*}{$\begin{array}{l}\text { OM } \\
\text { (\%) }\end{array}$} & \multirow{2}{*}{$\begin{array}{l}\text { TOC } \\
\text { (\%) }\end{array}$} & \multirow{2}{*}{$\begin{array}{l}\mathrm{TN} \\
(\%)\end{array}$} & \multirow{2}{*}{$\begin{array}{c}\text { TS } \\
(\%)\end{array}$} & \multirow{2}{*}{$\begin{array}{l}\mathrm{C} / \mathrm{N} \\
\text { ratio }\end{array}$} & \multirow{2}{*}{$\begin{array}{c}\mathrm{C} / \mathrm{S} \\
\text { ratio }\end{array}$} \\
\hline & $\mathrm{Al}(\%)$ & $\mathrm{Fe}(\%)$ & $\mathrm{Mn}$ & $\mathrm{Zn}$ & $\mathrm{Cr}$ & $\mathrm{Ni}$ & $\mathrm{Cu}$ & Co & As & $\mathrm{Cd}$ & $\mathrm{Pb}$ & $\mathrm{Hg}$ & Sand & Silt & Clay & & & & & & & & & \\
\hline 1 & 3.85 & 2.74 & 470.20 & 119.40 & 51.20 & 31.11 & 57.61 & 13.13 & 4.83 & 0.69 & 22.06 & 0.03 & 0.67 & 34.38 & 64.96 & $M$ & 9.36 & 6.66 & 10.26 & 1.18 & 0.35 & 0.40 & 3.38 & 2.99 \\
\hline 3 & 4.23 & 2.83 & 491.20 & 100.00 & 53.60 & 31.62 & 22.58 & 13.71 & 5.08 & 0.20 & 22.93 & 0.02 & 0.40 & 36.71 & 62.90 & M & 9.17 & 6.73 & 9.70 & 1.15 & 0.32 & 0.43 & 3.58 & 2.70 \\
\hline 5 & 3.88 & 2.81 & 501.00 & 110.40 & 52.40 & 31.28 & 39.09 & 13.24 & 5.28 & 0.19 & 22.71 & 0.02 & 0.21 & 35.84 & 63.95 & M & 9.26 & 6.81 & 9.16 & 1.19 & 0.33 & 0.39 & 3.59 & 3.08 \\
\hline 7 & 3.98 & 2.88 & 537.40 & 102.00 & 52.20 & 31.54 & 20.48 & 13.50 & 5.43 & 0.18 & 24.58 & 0.02 & 0.44 & 38.01 & 61.55 & M & 9.12 & 6.86 & 8.12 & 1.16 & 0.30 & 0.45 & 3.81 & 2.56 \\
\hline 9 & 4.02 & 2.87 & 485.20 & 102.80 & 54.20 & 31.73 & 22.54 & 13.27 & 5.63 & 0.19 & 23.13 & 0.02 & 0.35 & 35.05 & 64.60 & M & 9.35 & 6.86 & 8.23 & 1.06 & 0.30 & 0.48 & 3.54 & 2.22 \\
\hline 11 & 4.11 & 2.93 & 469.20 & 104.80 & 55.60 & 31.62 & 20.29 & 13.47 & 5.49 & 0.21 & 23.24 & 0.02 & 0.27 & 33.38 & 66.35 & M & 9.42 & 6.87 & 8.76 & 1.05 & 0.30 & 0.49 & 3.46 & 2.16 \\
\hline 13 & 3.85 & 2.80 & 450.40 & 100.60 & 51.80 & 30.26 & 22.38 & 13.30 & 4.83 & 0.19 & 22.40 & 0.02 & 0.21 & 34.06 & 65.73 & M & 9.34 & 6.89 & 8.68 & 1.06 & 0.30 & 0.52 & 3.54 & 2.05 \\
\hline 15 & 3.98 & 2.89 & 482.20 & 105.20 & 55.20 & 32.56 & 22.13 & 13.83 & 4.81 & 0.24 & 23.11 & 0.03 & 0.09 & 33.94 & 65.97 & M & 9.33 & 6.92 & 9.00 & 1.07 & 0.30 & 0.51 & 3.60 & 2.09 \\
\hline 17 & 4.14 & 2.87 & 523.20 & 107.20 & 55.60 & 31.27 & 28.01 & 13.32 & 4.76 & 0.21 & 22.78 & 0.02 & 0.10 & 32.63 & 67.27 & M & 9.43 & 6.92 & 8.68 & 1.09 & 0.27 & 0.51 & 3.97 & 2.13 \\
\hline 19 & 4.30 & 2.88 & 484.40 & 101.40 & 57.00 & 30.97 & 19.74 & 13.12 & 4.86 & 0.18 & 22.42 & 0.03 & 0.15 & 34.19 & 65.66 & M & 9.45 & 6.94 & 9.36 & 1.07 & 0.26 & 0.52 & 4.14 & 2.04 \\
\hline 21 & 3.83 & 2.73 & 493.20 & 102.60 & 52.20 & 29.55 & 33.43 & 12.42 & 4.47 & 0.16 & 20.92 & 0.02 & 0.11 & 32.53 & 67.37 & M & 9.44 & 6.94 & 9.13 & 1.05 & 0.27 & 0.48 & 3.93 & 2.21 \\
\hline 23 & 3.87 & 2.73 & 496.40 & 92.20 & 52.20 & 29.25 & 19.21 & 12.57 & 4.40 & 0.15 & 21.23 & 0.02 & 0.23 & 31.92 & 67.85 & M & 9.47 & 6.96 & 8.85 & 0.98 & 0.26 & 0.51 & 3.80 & 1.95 \\
\hline 25 & 3.80 & 2.77 & 431.00 & 95.20 & 52.60 & 29.90 & 17.82 & 12.78 & 4.35 & 0.17 & 20.79 & 0.02 & 0.10 & 33.23 & 66.67 & M & 9.42 & 6.96 & 8.36 & 1.03 & 0.27 & 0.47 & 3.89 & 2.18 \\
\hline 27 & 4.31 & 2.87 & 434.80 & 100.80 & 59.80 & 31.51 & 16.55 & 13.11 & 4.24 & 0.26 & 21.71 & 0.03 & 0.51 & 33.73 & 65.76 & M & 9.32 & 6.96 & 8.60 & 1.09 & 0.26 & 0.50 & 4.14 & 2.19 \\
\hline 29 & 4.48 & 2.92 & 491.20 & 104.00 & 59.40 & 31.54 & 19.59 & 13.19 & 4.25 & 0.23 & 22.39 & 0.02 & 0.21 & 34.53 & 65.26 & M & 9.29 & 6.96 & 8.30 & 1.14 & 0.30 & 0.55 & 3.76 & 2.06 \\
\hline 31 & 4.12 & 2.81 & 456.80 & 97.80 & 55.40 & 30.53 & 16.75 & 12.52 & 4.04 & 0.20 & 20.93 & 0.03 & 0.09 & 30.87 & 69.05 & M & 9.57 & 6.97 & 8.90 & 1.29 & 0.35 & 0.62 & 3.68 & 2.08 \\
\hline 33 & 4.67 & 2.93 & 563.60 & 103.60 & 61.60 & 30.91 & 19.41 & 12.99 & 4.62 & 0.24 & 22.05 & 0.03 & 0.08 & 32.71 & 67.21 & M & 9.50 & 6.97 & 9.58 & 1.11 & 0.26 & 0.50 & 4.34 & 2.20 \\
\hline 35 & 4.12 & 2.80 & 509.20 & 102.60 & 54.40 & 29.47 & 25.65 & 12.48 & 4.58 & 0.19 & 20.15 & 0.03 & 0.36 & 32.51 & 67.12 & M & 9.50 & 6.99 & 8.96 & 1.02 & 0.31 & 0.55 & 3.30 & 1.85 \\
\hline 37 & 3.74 & 2.68 & 580.40 & 104.00 & 51.80 & 27.75 & 34.29 & 12.01 & 4.06 & 0.14 & 19.43 & 0.02 & 0.46 & 34.26 & 65.29 & M & 9.36 & 6.99 & 9.10 & 1.05 & 0.30 & 0.50 & 3.51 & 2.11 \\
\hline 39 & 3.96 & 2.68 & 660.80 & 86.00 & 52.80 & 27.19 & 12.91 & 11.50 & 4.05 & 0.10 & 18.84 & 0.03 & 0.35 & 34.45 & 65.19 & M & 9.21 & 6.99 & 8.75 & 1.00 & 0.26 & 0.50 & .90 & 2.02 \\
\hline 41 & 3.94 & 2.72 & 601.60 & 92.80 & 53.20 & 27.80 & 19.16 & 11.93 & 3.89 & 0.11 & 19.59 & 0.02 & 0.13 & 35.87 & 64.00 & M & 9.20 & 7.00 & 8.45 & 1.06 & 0.25 & 0.48 & 4.17 & 2.20 \\
\hline 43 & 4.16 & 2.76 & 640.00 & 91.60 & 55.60 & 28.09 & 13.20 & 12.07 & 3.99 & 0.12 & 19.70 & 0.03 & 0.03 & 32.99 & 66.99 & M & 9.37 & 7.01 & 9.12 & 1.09 & 0.26 & 0.49 & 4.25 & 2.22 \\
\hline 45 & 4.13 & 2.76 & 682.20 & 97.20 & 56.00 & 27.71 & 23.37 & 11.71 & 4.20 & 0.42 & 19.42 & 0.02 & 0.01 & 16.50 & 83.49 & M & 9.34 & 7.03 & 8.63 & 1.05 & 0.25 & 0.47 & 4.16 & 2.26 \\
\hline 47 & 4.54 & 2.71 & 639.80 & 90.40 & 58.60 & 27.01 & 20.99 & 11.50 & 4.13 & 0.10 & 19.00 & 0.02 & 0.03 & 28.28 & 71.69 & M & 8.97 & 7.05 & 8.10 & 1.01 & 0.26 & 0.45 & 3.85 & 2.27 \\
\hline 49 & 4.33 & 2.77 & 694.40 & 88.00 & 56.20 & 27.97 & 12.55 & 12.08 & 4.09 & 0.09 & 19.17 & 0.02 & 0.07 & 30.17 & 69.76 & M & 9.35 & 7.05 & 8.35 & 1.14 & 0.26 & 0.39 & 4.47 & 2.90 \\
\hline 51 & 4.06 & 2.74 & 721.40 & 86.40 & 54.60 & 28.01 & 11.95 & 11.98 & 4.10 & 0.09 & 18.65 & 0.02 & 2.09 & 30.94 & 66.97 & M & 9.20 & 7.06 & 8.45 & 0.96 & 0.24 & 0.39 & 4.01 & 2.48 \\
\hline 53 & 4.50 & 2.80 & 723.80 & 93.00 & 61.40 & 29.48 & 20.52 & 12.23 & 4.22 & 0.13 & 18.87 & 0.02 & 1.45 & 31.46 & 67.09 & M & 9.21 & 7.08 & 8.41 & 1.02 & 0.26 & 0.38 & 3.87 & 2.68 \\
\hline 55 & 4.01 & 2.78 & 710.20 & 95.20 & 55.60 & 28.05 & 26.98 & 11.99 & 4.15 & 0.12 & 18.40 & 0.02 & 1.90 & 30.62 & 67.47 & M & 9.15 & 7.09 & 8.22 & 1.00 & 0.25 & 0.37 & 3.99 & 2.72 \\
\hline 57 & 4.21 & 2.69 & 686.60 & 116.80 & 56.80 & 27.17 & 64.97 & 11.85 & 4.04 & 0.10 & 17.68 & 0.02 & 0.58 & 32.34 & 67.08 & M & 9.27 & 7.09 & 8.23 & 0.99 & 0.25 & 0.32 & 3.92 & 3.07 \\
\hline 59 & 3.98 & 2.80 & 705.20 & 87.60 & 59.60 & 28.41 & 18.83 & 11.84 & 4.24 & 0.11 & 18.15 & 0.03 & 0.73 & 30.96 & 68.30 & M & 9.32 & 7.10 & 8.22 & 0.99 & 0.24 & 0.32 & 4.12 & 3.07 \\
\hline Min. & 3.74 & 2.68 & 431.00 & 86.00 & 51.20 & 27.01 & 11.95 & 11.50 & 3.89 & 0.09 & 17.68 & 0.02 & 0.01 & 16.50 & 61.55 & & 8.97 & 6.66 & 8.10 & 0.96 & 0.24 & 0.32 & 3.30 & 1.85 \\
\hline Max. & 4.67 & 2.93 & 723.80 & 119.40 & 61.60 & 32.56 & 64.97 & 13.83 & 5.63 & 0.69 & 24.58 & 0.03 & 2.09 & 38.01 & 83.49 & & 9.57 & 7.10 & 10.26 & 1.29 & 0.35 & 0.62 & 4.47 & 3.08 \\
\hline Avg. & 4.10 & 2.80 & 560.57 & 99.39 & 55.29 & 29.71 & 24.10 & 12.62 & 4.50 & 0.19 & 20.88 & 0.03 & 0.41 & 32.64 & 66.95 & & 9.32 & 6.96 & 8.76 & 1.07 & 0.28 & 0.46 & 3.86 & 2.36 \\
\hline ER-L & N/A & N/A & N/A & 150.00 & 81.00 & 20.90 & 34.00 & N/A & 8.20 & 1.20 & 46.70 & 0.15 & & & & & & & & & & & & \\
\hline ER-M & N/A & N/A & N/A & 410.00 & 370.00 & 51.60 & 270.00 & N/A & 70.00 & 9.60 & 218.00 & 0.71 & & & & & & & & & & & & \\
\hline
\end{tabular}


Biogeosciences Discuss., https://doi.org/10.5194/bg-2017-383

Manuscript under review for journal Biogeosciences

Discussion started: 1 November 2017

(c) Author(s) 2017. CC BY 4.0 License.

Table 4: Analysis results from the Constant Rate of Supply (CRS) model to calculate the age and sedimentation rates in sediment cores 11257 (A), 10863 (B) and 11285 (C), taken from Gamak Bay.

\begin{tabular}{|c|c|c|c|c|c|c|c|c|c|c|c|c|c|c|c|c|c|c|c|c|c|c|c|c|c|c|c|}
\hline \multirow{2}{*}{$\begin{array}{c}\text { Depth } \\
(\mathrm{cm})\end{array}$} & \multicolumn{3}{|c|}{$\begin{array}{c}\text { Total }{ }^{210} \mathrm{~Pb} \\
(\mathrm{mBq} / \mathrm{g})\end{array}$} & \multicolumn{3}{|c|}{$\begin{array}{l}\text { Supported }{ }^{210} \mathrm{~Pb} \\
(\mathrm{mBq} / \mathrm{g})\end{array}$} & \multicolumn{3}{|c|}{$\begin{array}{c}\text { Excess }{ }^{210} \mathrm{~Pb} \\
(\mathrm{mB} / \mathrm{g})\end{array}$} & \multicolumn{3}{|c|}{ Dry mass (g) } & \multicolumn{3}{|c|}{$\begin{array}{l}\text { Inventory Excess } \\
{ }^{210} \mathrm{~Pb}(\mathrm{mBq} / \mathrm{g})\end{array}$} & \multicolumn{3}{|c|}{ Estimated Year } & \multicolumn{3}{|c|}{ Date (year) } & \multicolumn{3}{|c|}{$\begin{array}{c}\text { Accumulation } \\
\text { rate }(\mathrm{g} / \mathrm{cm} 2 / \text { year })\end{array}$} & \multicolumn{3}{|c|}{$\begin{array}{l}\text { Sedimentation } \\
\text { rate (cm/year) }\end{array}$} \\
\hline & $\mathrm{A}$ & $\mathrm{B}$ & $\mathrm{C}$ & $\mathrm{A}$ & $\mathrm{B}$ & $\mathrm{C}$ & $\mathrm{A}$ & $\mathrm{B}$ & $\mathrm{C}$ & $\mathrm{A}$ & $\mathrm{B}$ & $\mathrm{C}$ & $\mathrm{A}$ & $\mathrm{B}$ & $\mathrm{C}$ & $\mathrm{A}$ & $\mathrm{B}$ & $\mathrm{C}$ & $\mathrm{A}$ & $\mathrm{B}$ & $\mathrm{C}$ & $\mathrm{A}$ & $\mathrm{B}$ & $\mathrm{C}$ & $\mathrm{A}$ & $\mathrm{B}$ & $\mathrm{C}$ \\
\hline $0-2$ & 64.7 & 81.1 & 93.3 & 12 & 12 & 26 & 52.7 & 69.1 & 67.3 & 1.57 & 1.34 & 1.28 & 99.7 & 113.3 & 72.2 & 0.0 & 0.0 & 0.0 & 2014 & 2014 & 2014 & & & & & & \\
\hline $2-4$ & 59.9 & 89.7 & 86.9 & & & & 47.9 & 77.7 & 60.9 & 1.07 & 1.30 & 1.27 & 87.5 & 131.3 & 58.8 & 4.2 & 2.1 & 1.3 & 2010 & 2012 & 2013 & 0.76 & 1.44 & 2.12 & 0.84 & 1.71 & 4.40 \\
\hline $4-6$ & 46.6 & 85.1 & 95.3 & & & & 34.6 & 73.1 & 69.3 & 0.97 & 1.36 & 1.37 & 63.4 & 125.0 & 71.2 & 8.4 & 4.8 & 2.4 & 2006 & 2009 & 2012 & 0.57 & 0.97 & 1.73 & 0.62 & 1.13 & 3.37 \\
\hline $6-8$ & 36.3 & 84.0 & 99.5 & & & & 24.3 & 72.0 & 73.5 & 1.44 & 1.26 & 2.10 & 48.9 & 125.3 & 133.1 & 11.9 & 7.6 & 3.7 & 2002 & 2006 & 2010 & 0.55 & 0.82 & 1.52 & 0.54 & 0.94 & 1.68 \\
\hline $8-10$ & 47.5 & 78.7 & 97.4 & & & & 35.5 & 66.7 & 71.4 & 0.98 & 1.33 & 1.89 & 68.8 & 118.3 & 81.4 & 14.8 & 10.7 & 6.5 & 1999 & 2003 & 2008 & 0.55 & 0.73 & 1.10 & 0.56 & 0.83 & 1.93 \\
\hline $10-12$ & 46.5 & 82.0 & 88.9 & & & & 34.5 & 70.0 & 62.9 & 0.99 & 1.48 & 2.92 & 67.0 & 126.3 & 116.7 & 19.4 & 13.8 & 8.3 & 1995 & 2000 & 2006 & 0.50 & 0.68 & 1.06 & 0.52 & 0.75 & 1.14 \\
\hline $12-14$ & 43.8 & 80.9 & 82.8 & & & & 31.8 & 68.9 & 56.8 & 0.81 & 1.62 & 1.64 & 63.2 & 126.0 & 67.4 & 24.6 & 17.6 & 11.0 & 1989 & 1996 & 2003 & 0.46 & 0.63 & 0.92 & 0.46 & 0.68 & 1.55 \\
\hline $14-16$ & 40.6 & 75.8 & 79.7 & & & & 28.6 & 63.8 & 53.7 & 0.79 & 1.55 & 2.22 & 54.3 & 118.0 & 94.4 & 30.5 & 21.9 & 12.7 & 1983 & 1992 & 2001 & 0.43 & 0.58 & 0.92 & 0.45 & 0.62 & 1.05 \\
\hline $16-18$ & 37.1 & 72.6 & 78 & & & & 25.1 & 60.6 & 52 & 1.15 & 2.04 & 2.49 & 48.7 & 112.2 & 96.6 & 36.6 & 26.4 & 15.2 & 1977 & 1988 & 1999 & 0.40 & 0.54 & 0.87 & 0.41 & 0.58 & 0.94 \\
\hline $18-20$ & 22.7 & 64.3 & 74.1 & & & & 10.7 & 52.3 & 48.1 & 0.89 & 1.73 & 1.26 & 20.6 & 93.0 & 45.9 & 43.2 & 31.5 & 18.1 & 1971 & 1983 & 1996 & 0.38 & 0.50 & 0.81 & 0.39 & 0.56 & 1.70 \\
\hline $20-22$ & 22.8 & 61.5 & 72.8 & & & & 10.8 & 49.5 & 46.8 & 1.13 & 1.54 & 1.77 & 22.8 & 95.9 & 58.8 & 46.5 & 36.4 & 19.5 & 1968 & 1978 & 1994 & 0.39 & 0.48 & 0.83 & 0.37 & 0.49 & 1.31 \\
\hline 22-24 & 25 & 59.4 & 71.9 & & & & 13.0 & 47.4 & 45.9 & 1.10 & 1.99 & 1.81 & 24.8 & 90.7 & 70.8 & 50.6 & 42.3 & 21.4 & 1963 & 1972 & 1993 & 0.39 & 0.45 & 0.82 & 0.41 & 0.47 & 1.06 \\
\hline $24-26$ & 20.6 & 56.4 & 73.9 & & & & 8.6 & 44.4 & 47.9 & 0.97 & 2.05 & 1.99 & 17.0 & 86.2 & 88.5 & 55.6 & 49.2 & 23.9 & 1958 & 1965 & 1990 & 0.38 & 0.42 & 0.80 & 0.38 & 0.43 & 0.87 \\
\hline $26-28$ & 18.5 & 45.1 & 75.1 & & & & 6.5 & 33.1 & 49.1 & 1.09 & 2.38 & 1.43 & 13.3 & 62.7 & 69.0 & 59.7 & 57.4 & 27.4 & 1954 & 1957 & 1987 & 0.38 & 0.39 & 0.76 & 0.38 & 0.41 & 1.08 \\
\hline $28-30$ & 25.9 & 38.5 & 67.8 & & & & 13.9 & 26.5 & 41.8 & 1.04 & 1.98 & 1.53 & 27.9 & 48.6 & 67.9 & 63.2 & 65.0 & 30.3 & 1951 & 1949 & 1984 & 0.39 & 0.37 & 0.73 & 0.39 & 0.40 & 0.90 \\
\hline $30-32$ & 24.2 & 32.4 & 66 & & & & 12.2 & 20.4 & 40 & 1.03 & 2.10 & 1.61 & 25.5 & 37.7 & 68.5 & 72.1 & 72.5 & 33.5 & 1942 & 1941 & 1981 & 0.36 & 0.35 & 0.71 & 0.35 & 0.38 & 0.83 \\
\hline $32-34$ & 17.7 & 22.1 & 63.5 & & & & 5.7 & 10.1 & 37.5 & 1.22 & 2.71 & 1.31 & 11.6 & 18.7 & 39.3 & 83.3 & 79.9 & 37.1 & 1931 & 1934 & 1977 & 0.33 & 0.34 & 0.68 & 0.33 & 0.37 & 1.30 \\
\hline $34-36$ & 17.5 & 21.3 & 63.1 & & & & 5.5 & 9.3 & 37.1 & 1.01 & 2.38 & 2.37 & 10.7 & 17.1 & 70.7 & 90.0 & 84.2 & 39.3 & 1924 & 1930 & 1975 & 0.33 & 0.34 & 0.68 & 0.34 & 0.37 & 0.72 \\
\hline 36-38 & 16.4 & 20.6 & 61.7 & & & & 4.4 & 8.6 & 35.7 & 0.92 & 2.35 & 1.18 & 8.9 & 15.5 & 40.3 & 97.8 & 88.8 & 43.8 & 1916 & 1925 & 1970 & 0.32 & 0.34 & 0.64 & 0.31 & 0.38 & 1.14 \\
\hline $38-40$ & 17.2 & 23.6 & 63.7 & & & & 5.2 & 11.6 & 37.7 & 1.17 & 2.37 & 1.40 & 10.3 & 21.7 & 44.9 & 106.1 & 93.6 & 46.6 & 1908 & 1920 & 1967 & 0.31 & 0.34 & 0.63 & 0.31 & 0.36 & 1.07 \\
\hline $40-42$ & & 21.8 & 50.3 & & & & & 9.8 & 24.3 & & 2.44 & 1.66 & & 17.6 & 29.1 & & 101.8 & 50.2 & & 1912 & 1964 & & 0.33 & 0.62 & & 0.37 & 1.03 \\
\hline $42-44$ & & 20.2 & 56.6 & & & & & 8.2 & 30.6 & & 2.36 & 1.15 & & 15.1 & 39.6 & & 110.5 & 52.7 & & 1904 & 1961 & & 0.32 & 0.62 & & 0.34 & 0.95 \\
\hline $44-46$ & & & 56.5 & & & & & & 30.5 & & & 1.04 & & & 36.8 & & & 56.4 & & & 1958 & & & 0.60 & & & 0.99 \\
\hline $46-48$ & & & 53.5 & & & & & & 27.5 & & & 2.22 & & & 66.0 & & & 60.3 & & & 1954 & & & 0.59 & & & 0.49 \\
\hline $48-50$ & & & 49.7 & & & & & & 23.7 & & & 2.00 & & & 46.8 & & & 68.9 & & & 1945 & & & 0.54 & & & 0.55 \\
\hline 50-52 & & & 43.4 & & & & & & 17.4 & & & 2.55 & & & 40.9 & & & 76.6 & & & 1937 & & & 0.51 & & & 0.43 \\
\hline $52-54$ & & & 40.7 & & & & & & 14.7 & & & 2.11 & & & 25.7 & & & 85.4 & & & 1929 & & & 0.48 & & & 0.54 \\
\hline $54-56$ & & & 35.7 & & & & & & 9.7 & & & 2.59 & & & 20.7 & & & 92.5 & & & 1922 & & & 0.46 & & & 0.43 \\
\hline 56-58 & & & 38 & & & & & & 12 & & & 1.61 & & & 18.7 & & & 99.5 & & & 1914 & & & 0.44 & & & 0.57 \\
\hline 58-60 & & & 35.2 & & & & & & 9.2 & & & 2.21 & & & 19.1 & & & 107.6 & & & 1906 & & & 0.42 & & & 0.41 \\
\hline
\end{tabular}


Biogeosciences Discuss., https://doi.org/10.5194/bg-2017-383

Manuscript under review for journal Biogeosciences

Discussion started: 1 November 2017

Biogeosciences

(c) Author(s) 2017. CC BY 4.0 License.

Discussions

(c) (1)

Appendix A: Numbers, relative abundance (\%), and statistical data for benthic foraminifera from sediment core 11257, taken from western area of Gamak Bay.

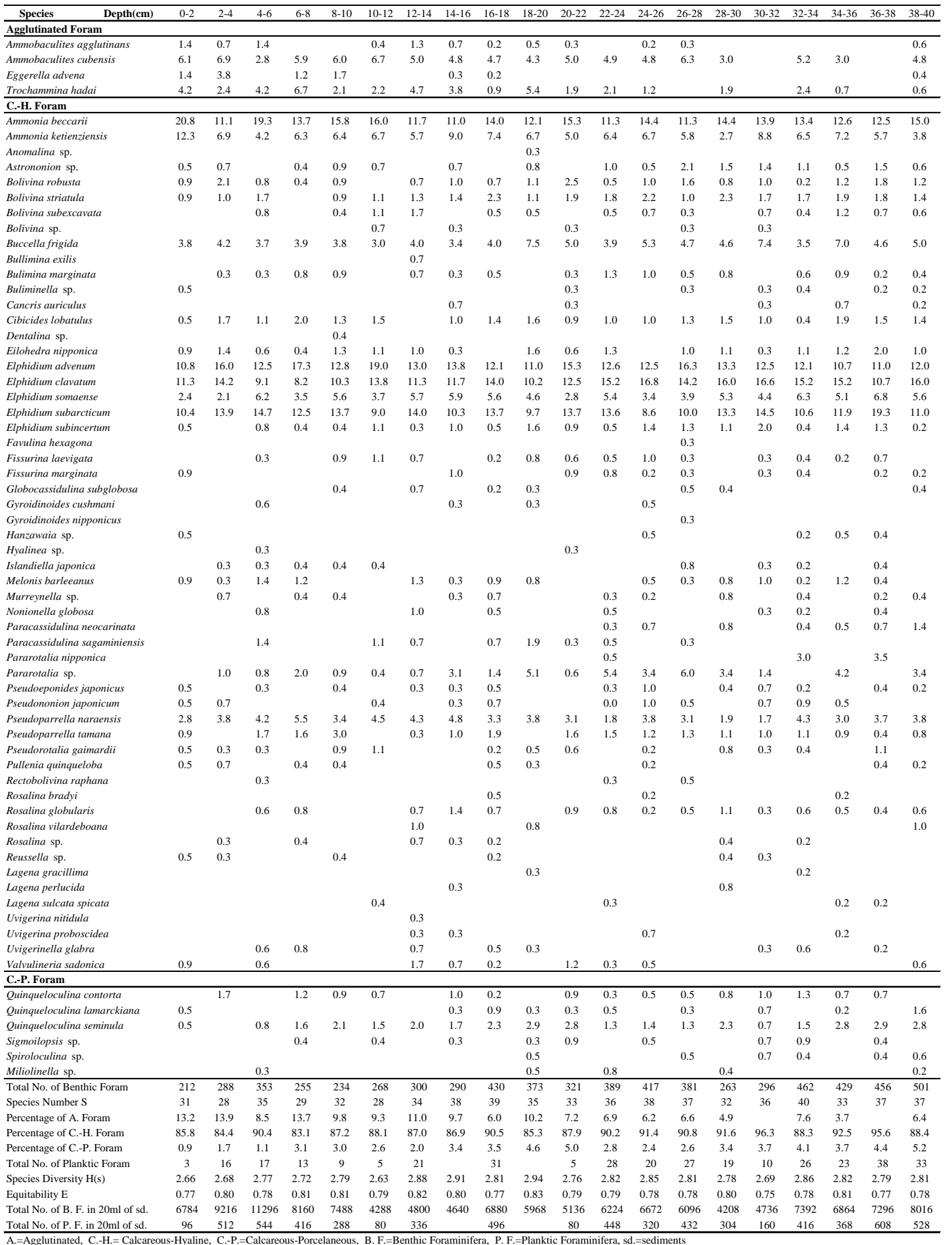


Biogeosciences Discuss., https://doi.org/10.5194/bg-2017-383

Manuscript under review for journal Biogeosciences

Discussion started: 1 November 2017

(c) Author(s) 2017. CC BY 4.0 License.

Appendix B: Numbers, relative abundance (\%), and statistical data for benthic foraminifera from sediment core 10863, taken from eastern area of Gamak Bay.

\begin{tabular}{|c|c|c|c|c|c|c|c|c|c|c|c|c|c|c|c|c|c|c|c|c|c|c|}
\hline Depth(cm) & $0-2$ & $2-4$ & $4-6$ & 6-8 & $8-10$ & $10-12$ & $12-14$ & $14-16$ & 16-18 & $18-20$ & $20-22$ & $22-24$ & $24-26$ & $26-28$ & $28-30$ & $30-32$ & $32-34$ & $34-36$ & $36-38$ & $38-40$ & $40-42$ & $42-44$ \\
\hline \multicolumn{23}{|l|}{ Agglutinated Foram } \\
\hline Ammobaculites agglutinans & 0.4 & 0.5 & & & & & & & & & & & & & 0.6 & & & & & & & \\
\hline Ammobaculites cubensis & 1.7 & 2.9 & & 0.4 & 1.3 & 1.4 & 1.0 & 0.5 & 0.8 & & 5.9 & 6.5 & 3.5 & 3.8 & 4.5 & 1.1 & 0.3 & 3.4 & 0.2 & 1.3 & 6.9 & 0.6 \\
\hline Eggerella advena & 1.7 & 1.0 & & & 0.5 & 0.4 & & & & & & 1.3 & 0.3 & 0.8 & & & & 0.3 & & 0.2 & & \\
\hline Trochammina hadai & 3.3 & 1.5 & 2.8 & 0.8 & 1.5 & 0.7 & 0.3 & & 0.4 & & 4.3 & 3.0 & 3.7 & 2.5 & 1.8 & & & 0.3 & 0.5 & 0.7 & 0.7 & \\
\hline \multicolumn{23}{|l|}{ C.-H. Foram } \\
\hline Ammonia beccarii & 9.6 & 14.1 & 11.7 & 19.3 & 13.5 & 15.4 & 22.0 & 19.1 & 14.6 & 18.8 & 14.6 & 15.2 & 14.4 & 13.5 & 15.9 & 18.8 & 17.1 & 13.7 & 14.6 & 11.7 & 10.7 & 10.1 \\
\hline Ammonia ketienziensis & 7.5 & 8.7 & 4.4 & 8.0 & 6.3 & 8.8 & 8.7 & 6.7 & 9.6 & 12.7 & 7.6 & 7.8 & 13.1 & 11.0 & 10.8 & 13.6 & 12.5 & 6.7 & 9.6 & 8.0 & 9.3 & 10.5 \\
\hline Astrononion sp. & 0.4 & & & & & 1.1 & & 0.5 & & & & & & 0.5 & & 0.6 & 0.3 & 0.8 & & 1.2 & 2.4 & 1.0 \\
\hline Bolivina robusta & 1.7 & 0.5 & 1.7 & 0.8 & & 1.1 & 1.0 & 1.0 & 0.4 & 1.5 & 0.5 & 0.9 & 1.3 & 0.8 & 0.6 & 1.1 & 0.3 & 0.8 & 1.2 & 1.4 & 1.7 & 0.8 \\
\hline Bolivina striatula & & & 1.1 & & 0.5 & 1.4 & 0.3 & 1.0 & 0.8 & & 0.5 & 0.9 & 0.5 & 0.3 & & 2.8 & 0.3 & 1.8 & 1.7 & 0.6 & 1.4 & 1.0 \\
\hline Bolivina subexcavata & & & & & & & & & & & & & 0.3 & 0.3 & & & & & & 0.1 & & 0.2 \\
\hline Buccella frigida & 4.2 & 1.9 & 2.8 & 4.4 & 4.1 & 4.9 & 4.2 & 4.1 & 4.2 & 5.1 & 3.2 & 4.8 & 2.7 & 4.4 & 1.8 & 3.4 & 4.9 & 3.1 & 3.6 & 3.1 & 5.5 & 3.1 \\
\hline Bulimina marginata & 0.8 & & 0.6 & 0.8 & 0.8 & 0.4 & 0.3 & & & 0.5 & & & & 0.8 & & 1.1 & 1.0 & & & 0.4 & 0.3 & 0.8 \\
\hline Buliminella sp. & & & & & & & & & & & & & & & & & & & & 0.2 & 0.3 & 0.2 \\
\hline Cancris auriculus & & & & & & & & & & & & & & & & & & & & 0.1 & & \\
\hline Cibicides lobatulus & & & & 1.6 & 1.0 & & 1.4 & 2.1 & & 0.5 & 1.6 & & 0.5 & 1.6 & 1.5 & & 2.0 & 2.3 & 2.2 & 1.6 & 0.7 & 1.3 \\
\hline Eilohedra nipponica & 0.8 & & & & & & & 0.5 & 0.8 & & 0.5 & & 1.1 & 1.1 & 0.9 & 0.6 & 1.0 & 1.3 & 0.5 & 1.5 & 1.4 & 1.7 \\
\hline Elphidium advenum & 7.9 & 7.3 & 7.8 & 8.4 & 5.8 & 8.1 & 12.9 & 6.2 & 10.0 & 13.2 & 12.4 & 11.7 & 13.1 & 13.7 & 12.0 & 20.5 & 16.4 & 13.0 & 13.7 & 11.5 & 17.9 & 17.2 \\
\hline Elphidium clavatum & 9.2 & 9.7 & 10.0 & 4.8 & 8.6 & 11.2 & 10.8 & 12.9 & 12.3 & 12.2 & 13.5 & 12.2 & 12.8 & 13.2 & 11.7 & 14.2 & 19.1 & 14.8 & 14.4 & 19.0 & 14.8 & 13.0 \\
\hline Elphidium somaense & 5.0 & 6.3 & 8.3 & 4.4 & 5.1 & 5.6 & 3.1 & 0.5 & 7.3 & 7.6 & 5.9 & 7.0 & 5.6 & 7.4 & 3.6 & 3.4 & 2.0 & 4.1 & 6.5 & 6.2 & 2.7 & 6.5 \\
\hline Elphidium subarcticum & 40.8 & 35.0 & 36.7 & 37.8 & 42.6 & 30.2 & 28.6 & 34.0 & 33.0 & 14.7 & 14.1 & 12.6 & 7.5 & 9.6 & 11.7 & 8.5 & 8.9 & 12.4 & 11.5 & 11.4 & 6.2 & 12.6 \\
\hline Elphidium subincertum & & & 1.1 & 0.8 & 0.5 & 0.7 & 0.7 & 0.5 & 0.8 & 0.5 & & 0.4 & 0.5 & 0.5 & 0.6 & 0.6 & 1.0 & 1.3 & 1.0 & 0.6 & 1.4 & 0.8 \\
\hline Favulina hexagona & & & & & & & & & & & & & & & & 0.6 & & & & & & \\
\hline Fissurina laevigata & & & & 0.8 & 0.3 & 0.7 & & & & & 1.1 & & 1.1 & & 0.3 & 0.6 & & & & 0.7 & 0.3 & \\
\hline Fissurina marginata & & 0.5 & & & & & & & & 1.0 & & & 0.3 & & & & & & 0.2 & 0.4 & & 0.2 \\
\hline Globocassidulina subglobosa & & & & & & & 0.3 & & & & & & 0.3 & & 0.6 & & 0.3 & & 0.5 & 0.4 & & 0.8 \\
\hline Gyroidinoides cushmani & & & & & 0.3 & & & & & & & & 0.5 & & & & & & 0.2 & & & \\
\hline Gyroidinoides nipponicus & & & & & 0.3 & & & & & & & & & 0.3 & & & & & & 0.1 & 0.3 & \\
\hline Hanzawaia sp. & & & & 0.4 & & & & & & & 1.6 & & 0.8 & 0.5 & & & & & 0.2 & 0.2 & 0.3 & \\
\hline Islandiella japonica & 0.4 & & & & & & & & & & & 0.4 & & & & 0.6 & & 0.3 & & & & \\
\hline Melonis barleeanus & & 1.0 & 0.6 & & 0.3 & 0.4 & & & & 1.5 & & & & 0.8 & 1.2 & 1.1 & & 0.3 & 1.7 & 0.2 & & 0.8 \\
\hline Murreynella sp. & & 0.5 & 0.6 & 0.4 & & & & 1.0 & 0.4 & 0.5 & 0.5 & 0.9 & & & & & 1.3 & & & 0.2 & & \\
\hline Nonionella globosa & & & & & & 0.4 & & & 0.4 & & & & 1.1 & & 0.9 & & & 0.5 & & & & \\
\hline Paracassidulina neocarinata & & & 2.2 & & & & & 2.1 & & & & & 0.8 & & 0.3 & & & & 0.2 & 0.2 & & 0.8 \\
\hline Paracassidulina sagaminiensis & & 0.5 & & & 0.5 & 1.1 & & & & & & 1.3 & 0.5 & 0.3 & 0.9 & & & & 0.7 & 0.5 & & \\
\hline Pararotalia nipponica & & & & 0.4 & 0.3 & & & & & & & & 0.3 & & 0.6 & & & & 0.2 & & & \\
\hline Pararotalia sp. & 1.3 & 1.0 & 2.2 & & 0.3 & & 0.7 & 2.1 & 1.5 & 0.5 & & 2.2 & 2.4 & 1.6 & 4.5 & & 1.3 & 3.6 & 2.9 & 2.8 & & 3.6 \\
\hline Pseudoeponides japonicus & & & & & & & & & & & & 0.4 & 0.5 & & & & & 0.3 & 0.2 & 0.1 & 0.3 & \\
\hline Pseudononion japonicum & & & & & & & & & & 0.5 & & & 0.5 & 0.5 & & & 0.3 & 1.0 & 0.2 & & & 0.4 \\
\hline Pseudoparrella naraensis & 1.3 & 1.9 & 1.7 & 2.4 & 2.0 & 1.8 & 0.7 & 3.1 & 1.5 & 4.6 & 4.3 & 2.6 & 3.5 & 3.0 & 3.0 & 0.6 & 2.6 & 4.1 & 4.6 & 3.3 & 1.0 & 2.9 \\
\hline Pseudoparrella tamana & & 1.9 & 2.2 & 2.4 & 2.0 & 2.1 & 2.1 & 2.1 & 0.8 & 2.0 & 2.2 & 2.2 & 1.6 & 1.1 & 1.5 & 1.7 & 2.3 & 1.0 & 1.9 & 1.6 & 3.8 & 1.7 \\
\hline Pseudorotalia gaimardii & 0.4 & & & 0.8 & & & 0.7 & & & 0.5 & 0.5 & 0.4 & 0.8 & 1.1 & 1.2 & & 1.0 & & 0.2 & 0.7 & 1.4 & 0.8 \\
\hline Pullenia quinqueloba & & & & & & & & & & & & & & & 0.3 & & & 0.3 & & & & \\
\hline Rectobolivina raphana & & & & & & & & & & & & & & & 0.3 & & & & 0.2 & & & \\
\hline Rosalina bradyi & & & & & 0.3 & & & & & & & 0.9 & 0.5 & 0.8 & & 0.6 & 1.0 & & & 0.4 & 0.7 & 0.6 \\
\hline Rosalina globularis & 0.8 & 0.5 & 0.6 & & 0.3 & & & & 0.4 & & & 1.3 & & 0.5 & & 1.1 & 0.7 & 0.8 & 0.7 & 0.6 & & 1.0 \\
\hline Rosalina sp. & 0.4 & 0.5 & & & & & & & & & & & & & & & & & & & & \\
\hline Lagena sulcata spicata & & 1.0 & & & & & & & & & & & & & & & & & & 0.1 & & \\
\hline Lenticulina sp. & & 0.5 & & & & & & & & & & & & & & & & & & & & \\
\hline Uvigerina proboscidea & & 0.5 & & & & & & & & & & 0.4 & & & & 0.6 & & & & & & \\
\hline Valvulineria sadonica & & & & & 0.3 & 0.7 & & & 0.4 & 1.0 & & & & & 0.9 & & & 0.8 & 0.2 & 0.5 & & 0.6 \\
\hline \multicolumn{23}{|l|}{ C.-P. Foram } \\
\hline Quinqueloculina contorta & & & & & & & & & & 0.5 & & & 0.3 & 1.1 & 0.3 & & 0.3 & 1.0 & 0.7 & 0.8 & 1.4 & 0.6 \\
\hline Quinqueloculina lamarckiana & & & & & & & & & & & & & 0.8 & & 0.9 & 1.1 & 1.3 & 1.6 & 0.5 & 0.7 & 2.1 & 1.0 \\
\hline Quinqueloculina seminula & 0.4 & 0.5 & 1.1 & & 1.0 & 1.8 & & & & & 3.8 & 2.6 & 2.1 & 2.2 & 3.3 & 1.1 & & 2.6 & 2.2 & 4.4 & 3.4 & 2.1 \\
\hline Sigmoilopsis sp. & & & & & & & & & & & 0.5 & & & & 0.6 & & 0.3 & 0.5 & & & 0.3 & 0.2 \\
\hline Spiroloculina sp. & & & & & & & & & & & 0.5 & & 0.3 & & 0.3 & & & 0.5 & 0.2 & 0.3 & 0.3 & \\
\hline Miliolinella sp. & & & & & & & & & & & & & 0.3 & & & & & 0.8 & & 0.2 & & \\
\hline Total No. of Benthic Foram & 240 & 206 & 180 & 249 & 394 & 285 & 287 & 194 & 261 & 197 & 185 & 230 & 375 & 364 & 333 & 176 & 304 & 386 & 417 & 1008 & 291 & 477 \\
\hline Species Number $\mathrm{S}$ & 22 & 25 & 20 & 20 & 27 & 23 & 19 & 19 & 20 & 21 & 22 & 25 & 37 & 31 & 33 & 25 & 27 & 33 & 35 & 43 & 30 & 33 \\
\hline Percentage of A. Foram & 7.1 & 5.8 & 2.8 & 1.2 & 3.3 & 2.5 & 1.4 & 0.5 & 1.1 & & 10.3 & 10.9 & 7.5 & 7.1 & 6.9 & 1.1 & 0.3 & 3.9 & 0.7 & 2.2 & 7.6 & 1 \\
\hline Percentage of C.-H. Foram & 92.5 & 93.7 & 96.1 & 98.8 & 95.7 & 95.8 & 98.6 & 99.5 & 98.9 & 99.5 & 84.9 & 86.5 & 88.8 & 89.6 & 87.7 & 96.6 & 97.7 & 89.1 & 95.7 & 91.5 & 84.9 & 95 \\
\hline Percentage of C.-P. Foram & 0.4 & 0.5 & 1.1 & & 1.0 & 1.8 & & & & 0.5 & 4.9 & 2.6 & 3.7 & 3.3 & 5.4 & 2.3 & 2.0 & 7.0 & 3.6 & 6.3 & 7.6 & 4 \\
\hline Total No. of Planktic Foram & 5 & 14 & 9 & 1 & 10 & & 6 & 2 & 3 & 5 & & 13 & 20 & 23 & 24 & & 10 & 24 & 27 & 91 & & \\
\hline Species Diversity H(s) & 2.17 & 2.28 & 2.25 & 2.09 & 2.12 & 2.33 & 2.10 & 2.14 & 2.12 & 2.38 & 2.59 & 2.68 & 2.83 & 2.75 & 2.79 & 2.42 & 2.46 & 2.80 & 2.70 & 2.80 & 2.74 & 2.75 \\
\hline Equitability E & 0.70 & 0.71 & 0.75 & 0.70 & 0.64 & 0.74 & 0.71 & 0.73 & 0.71 & 0.78 & 0.84 & 0.83 & 0.78 & 0.80 & 0.80 & 0.75 & 0.75 & 0.80 & 0.76 & 0.74 & 0.81 & 0.79 \\
\hline Total No. of B. F. in $20 \mathrm{ml}$ of sd. & 1920 & 1648 & 2880 & 996 & 1576 & 2280 & 1148 & 1552 & 2088 & 1576 & 2960 & 3680 & 3000 & 2912 & 5328 & 1408 & 2432 & 3088 & 3336 & 4032 & 2328 & 3816 \\
\hline Total No. of P. F. in $20 \mathrm{ml}$ of sd. & 40 & 112 & 144 & 4 & 40 & & 24 & 16 & 24 & 40 & & 208 & 160 & 184 & 384 & & 80 & 192 & 216 & 364 & & \\
\hline
\end{tabular}


Biogeosciences Discuss., https://doi.org/10.5194/bg-2017-383

Manuscript under review for journal Biogeosciences

Discussion started: 1 November 2017

(c) Author(s) 2017. CC BY 4.0 License.

(c) (1)

Appendix C: Numbers, relative abundance (\%), and statistical data for benthic foraminifera from sediment core 11285, taken from northwestern area of Gamak Bay.

\begin{tabular}{|c|c|c|c|c|c|c|c|c|c|c|c|c|c|c|c|c|c|c|c|c|c|c|c|c|c|c|c|c|c|c|}
\hline Depth(cm) & $0-2$ & $2-4$ & $\begin{array}{c}4-6 \\
\end{array}$ & $6-8$ & $8-10$ & $10-12$ & $12-14$ & $14-16$ & $16-18$ & $18-20$ & $20-22$ & $22-24$ & $24-26$ & $26-28$ & $28-30$ & $30-32$ & $32-34$ & $34-36$ & $36-38$ & $38-40$ & $\begin{array}{ll}40-42 \\
\end{array}$ & $42-44$ & $\begin{array}{lll}44-46 \\
\end{array}$ & $46-48$ & $48-50$ & $50-52$ & $52-54$ & $54-56$ & $56-58$ & $58-60$ \\
\hline \multicolumn{31}{|l|}{ Agglutinated Foram } \\
\hline Ammobaculites agglutinans & 1.2 & 0.9 & 0.3 & 0.2 & & 1.1 & & & & & & & & & 0.7 & & & 1.4 & 0.7 & 0.3 & & & & & & & & & & \\
\hline Ammobaculites cubensis & & 0.4 & & 0.4 & 0.3 & 1.1 & & 1.8 & & & & & & & 0.7 & 3.0 & 2.1 & 2.1 & & 1.6 & 1.2 & & & & 0.1 & & & & & 2.1 \\
\hline Eggerella advena & 8.2 & 4.7 & 3.7 & 13.8 & 4.2 & 4.5 & 4.0 & & 0.6 & 3.3 & & & & 1.9 & 2.7 & 4.5 & 1.1 & 2.7 & & 0.3 & & & & & & & & & & \\
\hline Textularia mariae & & & & & & & & & & & & & & & & & & 0.7 & & & & & & & & & & & & \\
\hline Trochammina hadai & 18.5 & 18.1 & 4.9 & 12.2 & 4.2 & 17.0 & 17.2 & 10.9 & 1.9 & 7.9 & 18.9 & 1.1 & 7.2 & 11.5 & 4.7 & 45.5 & 21.1 & 0.7 & 9.7 & 11.3 & 1.8 & 1.0 & & & & & & 0.4 & & \\
\hline \multicolumn{31}{|l|}{ C.-H. Foram } \\
\hline$\overline{\text { Ammonia beccarii }}$ & 14.0 & 12.6 & 15.0 & 8.1 & 8.2 & 33.0 & 37.4 & 30.0 & 18.1 & 13.2 & 3.3 & 9.7 & 8.0 & 11.5 & 32.2 & 9.1 & 9.5 & 17.1 & 17.5 & 23.6 & 17.9 & 45.1 & 84.2 & 68.7 & 55.2 & 44.6 & 49.6 & 41.8 & 37.1 & 48.3 \\
\hline Bolivina sp. & & & & & 0.2 & & & & 0.3 & & 0.5 & & & & & & 1.1 & 2.7 & & & 0.6 & & & & & & & & & \\
\hline Buccella frigida & 2.3 & 2.8 & 2.6 & 4.3 & 6.1 & 6.8 & 10.1 & 4.5 & 10.6 & 4.6 & 8.5 & 40.1 & 18.8 & 25.0 & 12.1 & 10.6 & 27.4 & 21.9 & 58.7 & 14.9 & 25.0 & 42.2 & 12.3 & 6.0 & 10.9 & 6.8 & 14.0 & 18.4 & 27.3 & 11.0 \\
\hline Bulimina marginata & & & & & & & & & & & & & & & & & & 1.4 & & & & & & & 0.1 & & & & & \\
\hline Cancris auriculus & & & & & & & & & & & & & & & & & & 0.7 & & & & & & & & & & & & \\
\hline Cibicides lobatulus & & & & & & 1.1 & & & & & & & & & & 1.5 & & 2.1 & & & & & & & & & & & & \\
\hline Eilohedra nipponica & & & & & & & & & & & & & & & & & & 3.4 & & & & & & & & & & & & 0.7 \\
\hline Elphidium advenum & & 0.9 & & 0.1 & 0.3 & 2.3 & 5.1 & 2.7 & 0.3 & & 0.9 & 0.6 & 0.7 & & 4.7 & & 1.1 & 5.5 & 2.2 & 2.6 & 3.6 & 2.9 & & 10.9 & 14.7 & 25.3 & 12.3 & 13.1 & 8.8 & 4.8 \\
\hline Elphidium clavatum & 0.8 & 1.7 & 0.9 & 0.3 & 1.0 & 1.1 & 2.0 & 3.6 & 3.5 & 1.3 & 1.9 & 1.9 & 0.7 & 1.9 & 12.1 & & & 6.2 & 0.4 & 1.9 & 6.5 & 1.0 & 1.8 & 3.5 & 4.6 & 4.0 & 7.5 & 8.6 & 8.8 & 8.3 \\
\hline Elphidium somaense & 0.6 & 2.8 & 1.2 & 0.9 & 1.0 & 4.5 & & & 0.6 & 2.0 & 2.8 & & & & 0.7 & 3.0 & 17.9 & 2.1 & 5.2 & 20.7 & 26.8 & & & 2.0 & 2.8 & 2.8 & & & & \\
\hline Elphidium subarcticum & 53.9 & 53.9 & 71.2 & 59.7 & 74.3 & 20.5 & 18.2 & 43.6 & 58.4 & 65.1 & 62.3 & 46.1 & 63.0 & 48.1 & 18.8 & 22.7 & 18.9 & 11.6 & 5.2 & 17.8 & 15.5 & 6.9 & & 5.0 & 6.3 & 5.6 & 8.8 & 13.5 & 12.9 & 14.5 \\
\hline Elphidium subincertum & & & & & 0.2 & & & & 0.6 & & & & 0.7 & & 1.3 & & & & & & & 1.0 & 1.8 & 2.5 & 2.1 & 1.6 & 2.6 & 2.5 & 4.1 & 3.4 \\
\hline Fissurina laevigata & & 0.2 & & & & & & & & & & & & & & & & 0.7 & & 0.3 & & & & & 0.1 & 0.8 & & & & \\
\hline Melonis barleeanus & & & & & & & 2.0 & & & & & & & & & & & 2.1 & & 0.3 & & & & & & & & & & \\
\hline Nonionella globosa & & & & & & & & & & & & & & & 0.7 & & & & & & & & & & & & & & & \\
\hline Paracassidulina sagaminiensis & & & & & & & 1.0 & & & & 0.9 & & & & & & & 2.1 & & & 0.6 & & & & & & & & & \\
\hline Pararotalia nipponica & & & & & & 1.1 & & & & & & & & & & & & 0.7 & & & & & & & & & & & & \\
\hline Pseudononion japonicum & & & & & & & & & & & & & & & & & & 2.1 & & & & & & & & & & & & \\
\hline Pseudoparrella naraensis & & 0.9 & & & & 2.3 & & & 0.3 & & & 0.6 & & & & & & 2.7 & & & & & & & & & & & & \\
\hline Rosalina sp. & & & & & & 1.1 & & & & & & & & & & & & 3.4 & 0.4 & & & & & & & & & & & \\
\hline \multicolumn{31}{|l|}{ C.P. Foram } \\
\hline Quinqueloculina seminula & 0.6 & & 0.3 & & & 2.3 & 3.0 & 2.7 & 4.2 & 2.6 & & & 0.7 & & 8.7 & & & 2.1 & & 4.2 & 0.6 & & & 1.5 & 2.9 & 8.4 & 3.1 & 1.6 & 1.0 & 6.2 \\
\hline Sigmoilopsis sp. & & & & & & & & & 0.3 & & & & & & & & & 2.1 & & & & & & & & & 2.2 & & & 0.7 \\
\hline Total No. of Benthic Foram & 514 & 531 & 347 & 1341 & 575 & 88 & 99 & 110 & 310 & 152 & 212 & 362 & 138 & 52 & 149 & 66 & 95 & 146 & 269 & 309 & 168 & 102 & 57 & 201 & 715 & 249 & 228 & 244 & 194 & 145 \\
\hline Species Number $\mathrm{S}$ & 9 & 12 & 9 & 10 & 11 & 15 & 10 & 8 & 13 & 8 & 9 & 7 & 8 & 6 & 13 & 8 & 9 & 25 & 9 & 13 & 11 & 7 & 4 & 8 & 11 & 9 & 8 & 8 & 7 & 10 \\
\hline Percentage of A. Foram & 27.8 & 24.1 & 8.9 & 26.6 & 8.7 & 23.9 & 21.2 & 12.7 & 2.6 & 11.2 & 18.9 & 1.1 & 7.2 & 13.5 & 8.7 & 53.0 & 24.2 & 7.5 & 10.4 & 13.6 & 3.0 & 1.0 & & & 0.1 & & & 0.4 & & 2.1 \\
\hline Percentage of C.-H. Foram & 71.6 & 75.9 & 91 & 73.4 & 91.3 & 73.9 & 75.8 & 84.5 & 92.9 & 86.2 & 81.1 & 98.9 & 92.0 & 86.5 & 82.6 & 47.0 & 75.8 & 88.4 & 89.6 & 82.2 & 96.4 & 99.0 & 100 & 98.5 & 96.9 & 91.6 & 94.7 & 98.0 & 99.0 & 91.0 \\
\hline Percentage of C.-P. Foram & 0.6 & & 0.3 & & & 2.3 & 3.0 & 2.7 & 4.5 & 2.6 & & & 0.7 & & 8.7 & & & 4.1 & & 4.2 & 0.6 & & & 1.5 & 2.9 & 8.4 & 5.3 & 1.6 & 1.0 & 6.9 \\
\hline Total No. of Planktic Foram & & 4 & 1 & 2 & & 1 & & & & & 2 & 1 & & & & 1 & & 9 & 1 & & 1 & & & 1 & 8 & & & & & \\
\hline Species Diversity H(s) & 1.36 & 1.48 & 1.02 & 1.28 & 1.02 & 2.02 & 1.80 & 1.50 & 1.36 & 1.23 & 1.22 & 1.13 & 1.14 & 1.35 & 1.98 & 1.57 & 1.75 & 2.67 & 1.31 & 1.95 & 1.81 & 1.15 & 0.54 & 1.17 & 1.48 & 1.60 & 1.57 & 1.61 & 1.59 & 1.66 \\
\hline Equitability E & 0.62 & 0.60 & 0.46 & 0.56 & 0.42 & 0.75 & 0.78 & 0.72 & 0.53 & 0.59 & 0.56 & 0.58 & 0.55 & 0.75 & 0.77 & 0.75 & 0.80 & 0.83 & 0.60 & 0.76 & 0.75 & 0.59 & 0.39 & 0.56 & 0.62 & 0.73 & 0.76 & 0.77 & 0.82 & 0.72 \\
\hline Total No. of B. F. in $20 \mathrm{ml}$ of s & 1028 & 1062 & 694 & 2682 & 1150 & 88 & 99 & 110 & 310 & 304 & 424 & 362 & 138 & 52 & 149 & 66 & 95 & 292 & 538 & 309 & 168 & 102 & 57 & 804 & 1430 & 996 & 912 & 488 & 388 & 1160 \\
\hline Total No. of P. F. in $20 \mathrm{ml}$ of sd. & & 8 & 2 & 4 & & 1 & & & & & 4 & 1 & & & & 1 & & 18 & 2 & & 1 & & & 4 & 16 & & & & & \\
\hline
\end{tabular}

